San Jose State University

SJSU ScholarWorks

Master's Theses

Master's Theses and Graduate Research

1997

\title{
In situ chemical characterization of cold seep fluid in Monterey Bay, California
}

Laurie Jean Ferioli

San Jose State University

Follow this and additional works at: https://scholarworks.sjsu.edu/etd_theses

\section{Recommended Citation}

Ferioli, Laurie Jean, "In situ chemical characterization of cold seep fluid in Monterey Bay, California" (1997). Master's Theses. 1439.

DOI: https://doi.org/10.31979/etd.4ket-m2gm

https://scholarworks.sjsu.edu/etd_theses/1439

This Thesis is brought to you for free and open access by the Master's Theses and Graduate Research at SJSU ScholarWorks. It has been accepted for inclusion in Master's Theses by an authorized administrator of SJSU ScholarWorks. For more information, please contact scholarworks@sjsu.edu. 


\section{INFORMATION TO USERS}

This manuscript has been reproduced from the microfilm master. UMI films the text directly from the original or copy submitted. Thus, some thesis and dissertation copies are in typewriter face, while others may be from any type of computer printer.

The quality of this reproduction is dependent upon the quality of the copy submitted. Broken or indistinct print, colored or poor quality illustrations and photographs, print bleedthrough, substandard margins, and improper alignment can adversely affect reproduction.

In the unlikely event that the author did not send UMI a complete manuscript and there are missing pages, these will be noted. Also, if unauthorized copyright material had to be removed, a note will indicate the deletion.

Oversize materials (e.g., maps, drawings, charts) are reproduced by sectioning the original, beginning at the upper left-hand comer and continuing from left to right in equal sections with small overlaps. Each original is also photographed in one exposure and is included in reduced form at the back of the book.

Photographs included in the original manuscript have been reproduced xerographically in this copy. Higher quality 6" $x$ 9" black and white photographic prints are available for any photographs or illustrations appearing in this copy for an additional charge. Contact UMI directly to order.

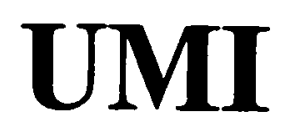

A Bell \& Howell Information Company 



\title{
IN SITU CHEMICAL CHARACTERIZATION OF COLD SEEP FLUID IN MONTEREY BAY, CALIFORNIA
}

\author{
A Thesis \\ Presented to San Jose State University \\ and \\ Moss Landing Marine Laboratories
}

In Partial Fulfillment

of the Requirements for the Degree

Master of Science

\author{
By \\ Laurie Jean Ferioli \\ May, 1997
}


UMI Number: 1384688

\section{Copyright 1997 by \\ Ferioli, Laurie Jean}

All rights reserved.

UMI Microform 1384688

Copyright 1997, by UMI Company. All rights reserved.

This microform edition is protected against unauthorized copying under Title 17, United States Code.

\section{UMI}

300 North Zeeb Road

Ann Arbor, MI 48103 
APPROVED FOR MOSS LANDING MARINE LABORATORIES

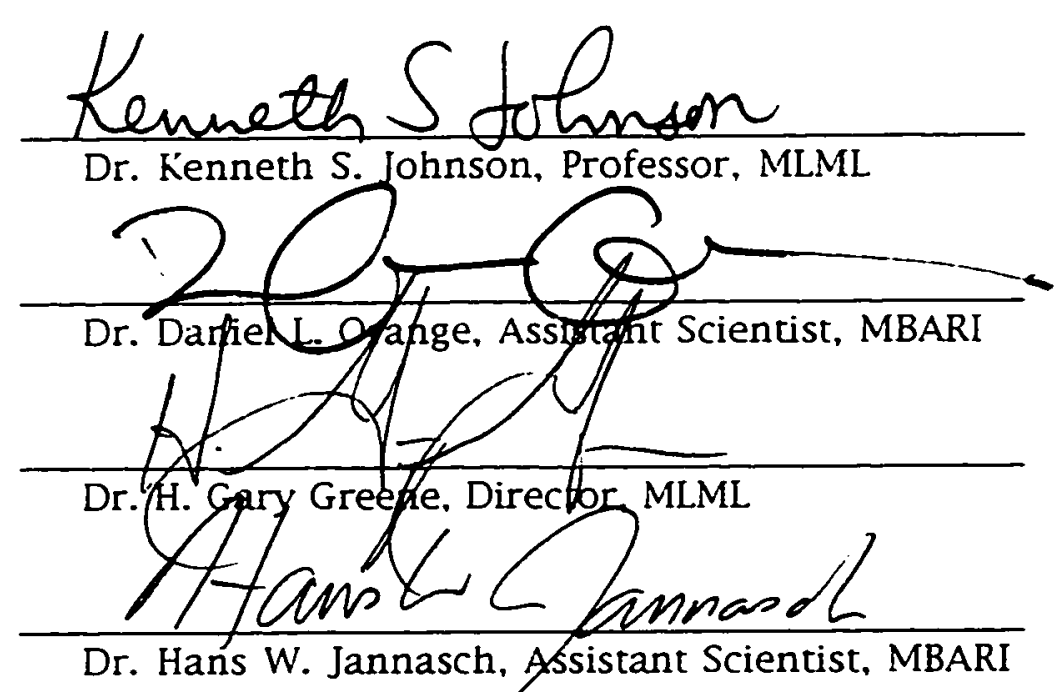
Willow. Brenton

Dr. William W. Broenkow, Professor, MLML

APPROVED FOR THE UNIVERSITY In. Lou Tewardowati 
(c) 1997

Laurie Jean Ferioli

ALL RIGHTS RESERVED 


\section{ABSTRACT \\ IN SITU CHEMICAL CHARACTERIZATION OF COLD SEEP FLUID IN MONTEREY BAY, CALIFORNIA \\ by Laurie J. Ferioli}

Cold seeps are generated when interstitial fluids of deep sediments move to the sediment-water interface. Tectonic compression, hydrocarbon formation, and aquifer forcing are possible geological processes capable of moving deep interstitial fluids. The complex geological nature of the Monterey Bay region precludes a single geological process functioning within a cold seep region, however, a single process may be predominant. Fluid composition varies between expulsion methods because of associated initial source fluid and diagenic processes.

Four cold seep sites were studied utilizing submersible chemical analyzers to determine the concentrations of silicate, $\mathrm{S}^{2-}, \mathrm{Mn}^{2+}$, and $\mathrm{Fe}^{2+}$. Sites studied showed distinctive chemical fingerprints associated with the predominant geological process and initial source fluid. Sulfide concentrations deviated most notably with highest concentrations associated with a conjectured hydrocarbon formation site, inter mediate values at a possible tectonic compression site, and lowest values at the sites thought to be dominated by aquifer forcing. 


\section{ACKNOWLEDGMENTS}

I wish to thank my husband, Craig Adams, who supported, encouraged, endured, and understood throughout the years. Thanks for the weeks I spent at sea while you dealt with the home front. Without your unwavering support. I would not have completed this work and would be a lesser person for it.

I would like to thank my committee members Dr. Ken Johnson, Dr. Dan Orange, Dr. Gary Greene, Dr. Hans Jannasch, and Dr. William Broenkow for their guidance and assistance.

I am indebted to The Monterey Bay Aquarium Research Institute (MBARI) for providing the essential ingredients for my research. MBARI generously provided a student internship, lab space, engineering support, and time on the ROV Ventana and her support ship Point Lobos. I wish to express my gratitude to Dan Orange, Gary Greene, Jim Barry, and Debra Stakes for contributing ROV dives.

A very special thanks to Dan Orange who kept the momentum of this project moving forward. Dan generously provided most of the ROV time required for my thesis, as well as guidance in performing deep sea research.

Ken Johnson was the inspiration behind my work, providing the equipment and expertise associated with in situ colorimetric chemistry. Ken, thanks for the introduction to a technique that led me to an adventure of a lifetime.

Gary Massoth kindly provided the SUAVE chemical analyzer from NOAA/PMEL for my August 1994 through September 1994 work in Monterey Bay. He additionally sponsored my attendance on the Atlantis II leg 131-16, where he endeavored to teach me everything he knew. The time I spent on the AII with Gary was educational and inspirational, not to mention 
pleasurable. My appreciation for light opera as well as my techniques in chemistry have significantly improved.

I was fortunate to have the guidance and support of Kenneth Coale who became both my mentor and friend. Words cannot begin to express my appreciation for his constant encouragement, kind words, and great smile.

Thanks to the officers and crew of the Point Lobos who carried my gear and provided good company, especially on the days of bad weather. My sincere gratitude to the pilots of the Ventana, Craig (T.C.) Dawe, Jim McFarlane, Chris Grech, and Mike Conway, who, without fail, placed my intake sampler in just the right place.

T. C. has a special place in my heart for working miracles and integrating the scanners with the Ventana. T. C.: Thanks for the hours of overtime, the wiring and rewiring, and the patience with my inability to tell $\mathrm{AC}$ from $\mathrm{DC}$.

Hans Jannasch and Carol Sakamoto guided me through the process of developing "real data" from "raw data." Your comments and directions were imperative to this work. Thanks to Norm Mayer who took countless hours to help map the areas from which my samples were taken.

Chris Harrold and Sue Lisin of the Monterey Bay Aquarium (MBA) generated my initial interest in the deep sea clam Calyptogena. You taught me both the need for good scientific technique as well as the need to be flexible. My work at MBA led to further studies with Ken Johnson in sulfide concentrations at cold seeps and eventually my thesis project.

I'd like to thank Liz Screaton and Ken Feldman who helped me thought my first "solo" cruise using the SCANNER.

Ray McClain and Stephanie Flora worked diligently to help me process my photos and maps. Thanks for your time and help. 
I am fortunate to have friends like Linda and Ray Curry who showed incredible bravery by allowing me to take their Powerbook to sea. The Powerbook gave me a stable computer platform during my field work.

This document was greatly enhanced by Ellen Fenwick, who endeavored to edit my script knowing little about deep-sea environments but providing guidance where needed.

Ginger Elrod, Jocelyn Nowicki, and Eric Kingsley provided constant support thoughout my tenure at Moss Landing Marine Labs. Eric, without complaint, helped me pack and transfer gear to and from labs, cars, ships, and planes.

In addition, I'd like to thank Randy Kochevar who helped focus my work at a time when I was floundering and Judith Connor who provided video support for all of my Ventana dives.

My parents, Robert and Gladys Ferioli, provided the background essential for my masters by supporting my undergraduate degree.

The presentation of this work at the 1994 American Geophysical Union Fall Meeting was funded by the David and Lucille Packard Foundation; for this support I am very fortunate and grateful.

The Office of Naval Research supported this work through research grant ONR \# NOOO14-89-J-1010.

There are countless others to thank whom I have not mentioned. Forgive your exclusion and accept my thanks, for without you I would not have accomplished this work. 


\section{PREFACE}

My tenure at San Jose State University (SJSU) and Moss Landing Marine Laboratories (MLML) has brought me a varied technical and educational experience. Coursework through the SJSU Environmental Studies Department provided me with a broad understanding of environmental law, economics, management, policies, and politics. MLML thrust me into the harsh reality of science at sea and the deep ocean.

I was truly fortunate to participate in various research projects that broadened my field study experience. These studies covered currents in the Gulf of California, accretionary prisms of the American Ridge off the coast of Costa Rica, hydrothermal vent systems of the Juan de Fuca Ridge off the coast of Oregon, and iron enrichment of the equatorial Pacific during IronEx II. These projects distracted me from my primary research plan, but gave me a extensive education in oceanography, geology, and biogeochemistry.

My work on cold seep chemistry in the Monterey Bay, presented in this thesis, was developed from an interest in chemosynthetic organisms and the ecosystems that support them. I was naive enough to believe the scheme I proposed was a simple project requiring minimal field time and sampling. I quickly learned that biogeochemistry at sea requires knowledge in electronics, computers, and construction as well as an understanding of $\mathrm{my}$ hypothesis. Fortunately, I had the help of an enormous number of talented individuals who shared their expertise with me and made this project a success.

I am thankful that my masters thesis project is able to present new information on cold seep chemistry. I am hopeful that this work can be expanded and verified by further research. 


\section{CONTENTS}

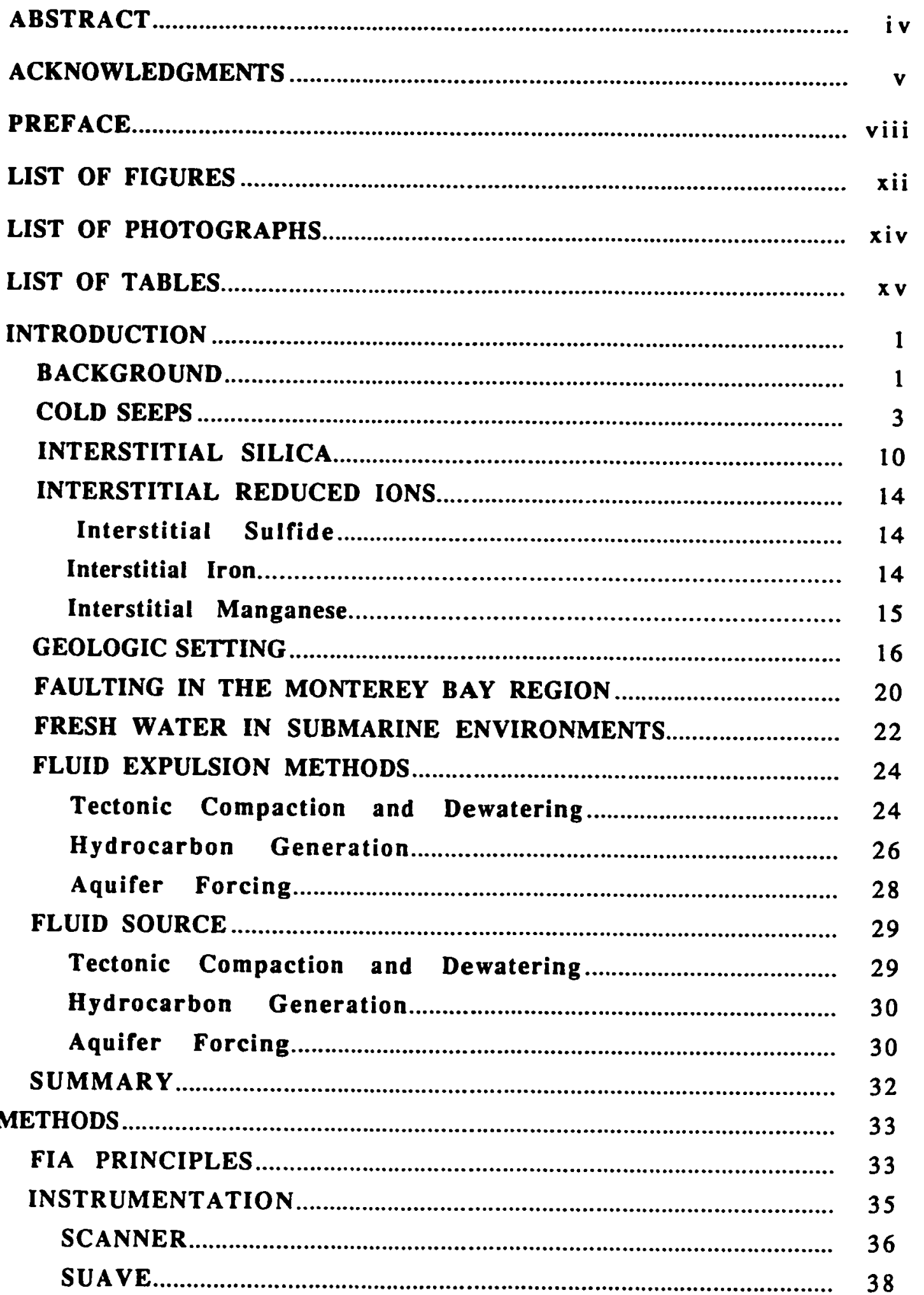


CHEMICAL ANALYSIS.................................................................. 40

Sulfide Analysis.......................................................................... 40

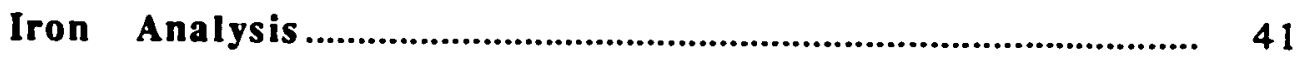

Manganese Analysis.................................................................. 43

Silicate Analysis........................................................................ 44

Working Standards.................................................................... 45

RESEARCH VESSELS...................................................................... 47

SAMPLING STRATEGY ...................................................................... 49

BACKGROUND CONCENTRATIONS................................................. 49

SAMPLE GATHERING ................................................................... 49

CONSERVATIVE AND NONCONSERVATIVE IONS.......................... 52

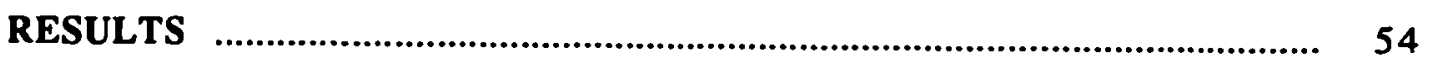

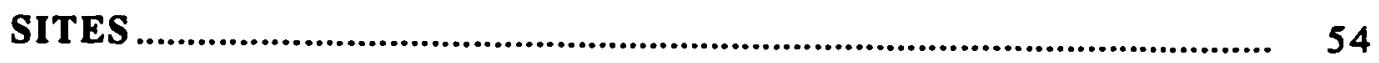

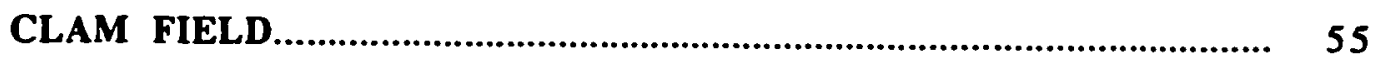

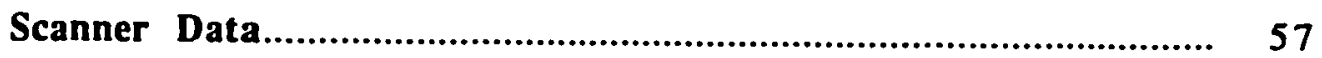

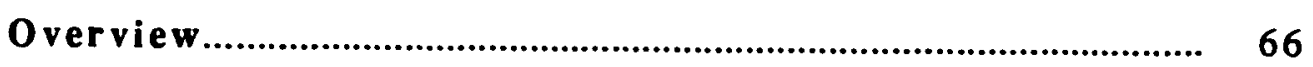

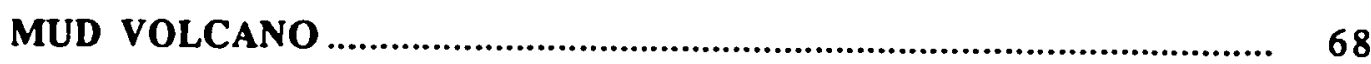

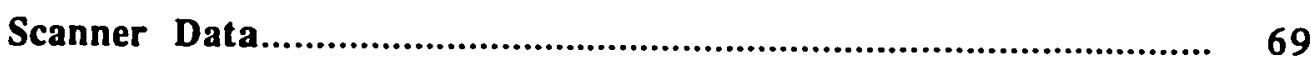

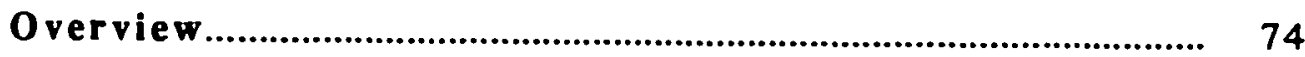

MOUNT CRUSHMORE ...................................................................... 77

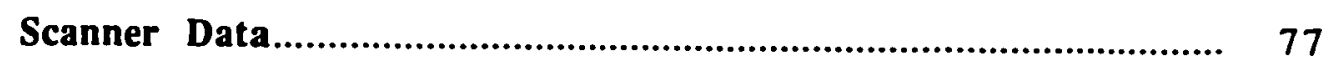

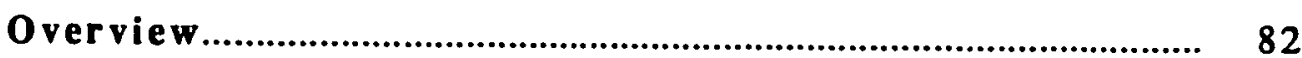

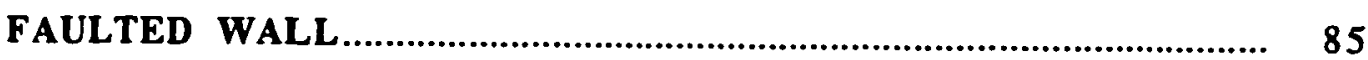

Scanner Data

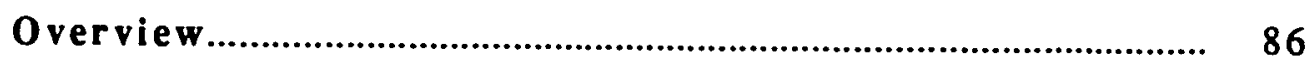

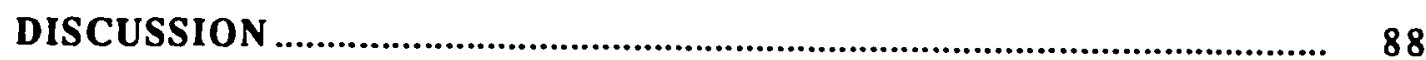

STATISTICAL ANALYSIS ............................................................... 88

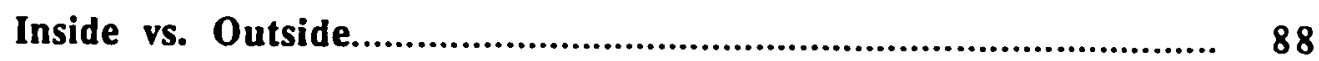

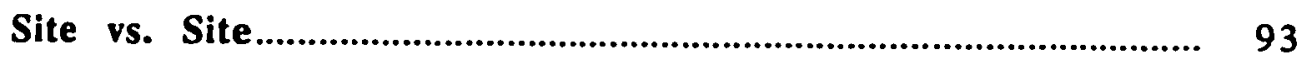

RELATIVE CONCENTRATIONS....................................................... 95

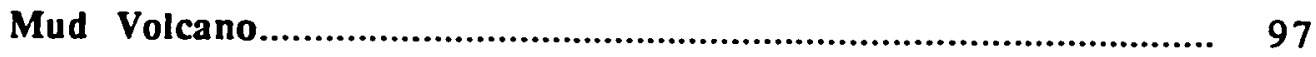

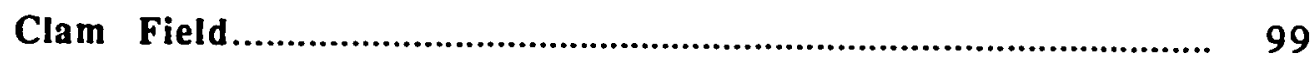

Mount Crushmore...................................................................... 100

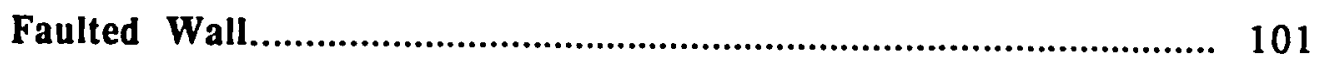




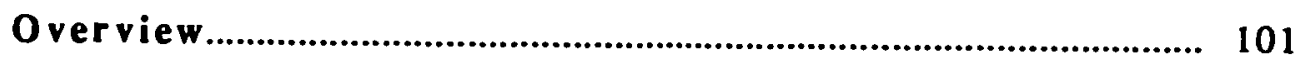

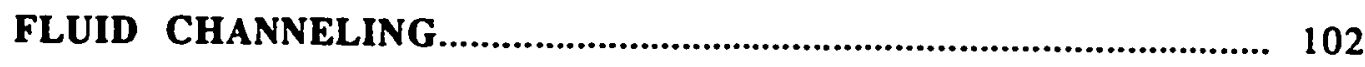

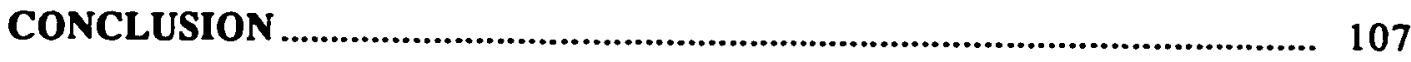

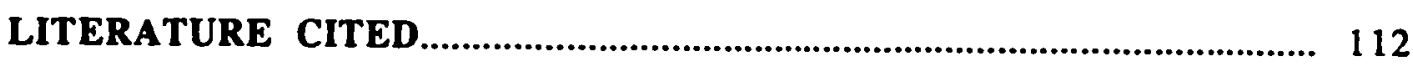

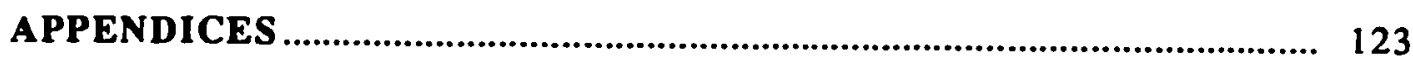

Appendix A: Concentrations of $\mathrm{S}^{2 \cdot}, \mathrm{Fe}^{2+}, \mathrm{Mn}^{2+}$, and

S i

Appendix B: Statistical analysis of ion concentrations found inside and outside active seep stations.................. 132

Appendix C: Statistical analysis of ion concentrations found between seep sites of inside active seep stations 144 


\section{LIST OF FIGURES}

Figure

1 Idealized depth profiles of manganese, nitrogen, iron, sulfur, and methane.

2 Pore water profiles of manganese and iron.

3 Diagram of the position Calyptogena sp. resides in sediments...... 10

4 Typical pore water profile of silicic acid....................................... 11

5 Manganese, iron, and silicate concentrations of interstitial fluids of sediments located south-west of Monterey Bay............... 13

6 Monterey Bay region fault zones................................................ 17

7 Submarine canyons of the Monterey Bay region......................... 18

8 Groundwater subbasins in the Monterey Bay Region.................. 23

9 Three fluid expulsion processes capable of creating overpressure and moving fluids to the sediment surface..................... 25

10 Illustration of sediment compaction ............................................. 24

11 FIA system of sampling........................................................... 33

12 FIA analysis of sulfide as described by Sakamoto-Arnold, Johnson, and Beehler (1986).......................................................... 35

13 SUAVE configuration............................................................... 42

14 Sample strategy at active seep regions....................................... 50

15 Entrainment of sea water during sampling.............................. 51

16 Idealized graphs of conservative and nonconservative ions....... 53

17 Site Location Map ....................................................................... 56

18 Timeline graph for sulfide and silicate concentrations from MBARI Ventana dive 698 on January 10, 1994 at Clam Field........ 58

19 Sulfide concentration vs. silicate concentration at Clam Field, January 10, 1994, MBARI Ventana dive 698. 
20 Timeline graph of sulfide, iron, manganese, and silicate concentrations from MBARI Ventana dives 796 and 797. September 6, 1994 at Clam Field

21 Sulfide, manganese, iron concentrations vs. silicate concentration at Clam Field for dives 796 and 797, on September 6, 1994

22 Timeline graph of sulfide and manganese concentrations from MBARI Ventana dive 806 at Clam Field on September 26, 1994.... 64

23 Timeline graph of sulfide concentrations from MBARI Ventana dive 699 at Mud Volcano, January 11, 1994.

24 Timeline graph of sulfide and manganese concentrations for MBARI Ventana dive 800 at Mud Volcano. September 13, 1994

25 Timeline graph from sulfide, iron, manganese, and silicate concentrations for MBARI dive 803 of September 20, 1994 at Mud Volcano

26 Sulfide, iron, and manganese concentrations vs. silicate concentration at Mud Volcano for dive 803 on September 20, 1994.

27 Timeline graph of sulfide and manganese concentrations from MBARI Ventana dive 787 at Mount Crushmore on August 12, 1994.

28 Timeline graph of sulfide, iron, manganese, and silicate for MBARI Ventana dive 790 at Mount Crushmore, on August 18, 1994

29 Figure 29. Sulfide, iron, and manganese concentrations vs. silicate concentration at Mount Crushmore for dive 790 on August 18, 1994

30 Timeline graph of sulfide, iron, and manganese for MBARI Ventana dive 792 at Faulted Wall on August 22, 1994.

31 Concentrations of the analytes sulfide, iron, manganese, and silicate by analyte.

32 Concentrations of the analytes sulfide, iron, manganese, and silicate by site

33 Outside and inside average concentrations by site.

34 Timeline graph of sulfide and silicate concentrations across an active seep site 


\section{LIST OF PHOTOGRAPHS}

\section{Photograph}

Page

1 The MBARI Remotely Operated Vehicle (ROV) Ventana.................. 48

2 The Ventane support ship, the research vessel Point Lobos........ 48

3 Clams often congregate in cervices where sediments collect....... 105

4 Orange and white bacterial mat at Mount Crushmore.................... 105

5 Clams are distributed over a wide area at Clam Field....................... 106

6 Clams collect around dark patches of sediments............................. 106 


\section{LIST OF TABLES}

Table

Page

1 Cold seep sites and publications referenced .................................... 4

2 Redox reactions of organic matter............................................... 7

3 Fluid expulsion methods and expected relative ion concentration for sulfide, reduced iron, reduced manganese, and silicate......... 33

4 Standards as prepared for SCANNER chemistry ............................. 46

5 Standards as prepared for SUAVE chemistry ............................... 46

6 Calculated background silicate concentrations by site................. 49

7 Site name, latitude, longitude and approximate depth in meters

8 Collection site, MBARI dive number, Julian day, date, and instrument.

9 Location of sample relative to active seep region and concentrations of $\mathrm{S}^{2-}, \mathrm{Fe}^{2+}, \mathrm{Mn}^{2+}$, and silicate determined at Clam Field.

10 Clam Field minimum, maximum, and average concentrations of the ions $\mathrm{S}^{2-}, \mathrm{Fe}^{2+}, \mathrm{Mn}^{2+}$, and silicate for inside and outside active seep sites.

11 Concentrations of sulfide, iron, manganese, and silicate determined at Mud Volcano.

12 Mud Volcano minimum, maximum, and average concentrations of $\mathrm{S}^{2-}, \mathrm{Fe}^{2+}, \mathrm{Mn}^{2+}$, and silicate for inside and outside active seep sites

13 Concentrations of sulfide, iron, manganese, and silicate determined at Mount Crushmore

14 Mount Crushmore minimum and maximum concentrations of the reduced ions $\mathrm{S}^{2-}, \mathrm{Fe}^{2+}, \mathrm{Mn}^{2+}$, and silicate for inside and outside active seep sites

15 Concentrations of sulfide, iron, manganese, and silicate determined at Faulted Wall

16 Overview of statistical analysis of inside vs. outside concentrations of $\mathrm{S}^{2-}, \mathrm{Fe}^{2+}, \mathrm{Mn}^{2+}$, and $\mathrm{Si}$ 
17 Relative ion concentration for sulfide, reduced iron,

reduced manganese, and silicate found at active seep sites........... 98

18 Relative concentration of ions of tested sites................................ 108 


\section{INTRODUCTION}

\section{BACKGROUND}

One of the most exciting discoveries of biological oceanography in recent decades has been the detection of chemoautotrophic bacteria and their symbiotic relationship with macrobiology on the seafloor (Childress, Felbeck, and Somero, 1987; Corliss et al., 1979; Lonsdale, 1977). These chemosynthetic organisms are found at hydrothermal vents on mid-ocean ridges, as well as cold seeps along continental margins. They represent previously unknown metabolic mechanisms utilized by organisms to obtain nutrition in the deepsea (Hessler and Kaharl, 1995; Jannasch, 1995).

The environments that support chemosynthetic organisms at hydrothermal vent regions have been well studied (e.g., Humphris et al., 1995; Jannasch, 1983; Morton, Zierenberg, and Reiss, 1994; Rona et al., 1983; Suess et al., 1985). In contrast, cold seep environments, supporting similar biological communities, are not as well understood. The Monterey Bay region, with its diverse geological and physiographical conditions, provides a unique location to study the environment that supports these remarkable ecosystems.

A cold seep is a region of the seafloor where interstitial fluids, rich in reduced ions, especially sulfide, are forced to the sediment surface via fractures in sediments. The term "cold" in cold seeps is often misinterpreted to indicate fluids that are colder than the surrounding environment. This term, however, more rightly indicates that the fluids are not "hot," but rather at or near the ambient temperature of the surrounding sea water.

The interstitial fluids in a cold seep are not driven to the surface by a reduction in their density due to heating, as in hydrothermal vents. The fluid must be pushed to the sediment surface by fluid pressure in excess of the 
surrounding hydrostatic pressure. Tectonic compaction, aquifer forcing, and hydrocarbon formation have been identified as processes capable of producing excess pore pressure. These processes can generate sufficient pressure to impel fluids from sediments when conduits to the surface are available.

The initial source fluid, which eventually evolves into seep fluids, varies among fluid expulsion methods and provides distinct chemical features to a seep. Initial source fluids include: Sea water at tectonic compaction sites, fresh groundwater at aquifer forcing sites, and organic material transformed to hydrocarbons at hydrocarbon formation sites.

The fluid composition and chemical signature may be further altered by diagenetic reactions as it flows to the surface through conduits of fractured rock or permeable sediments. Diagenesis is a complex system of chemical and biological reactions that modifies the sediment and its interstitial fluids. Each cold seep site has variations in the chemical signature of interstitial fluids that are produced by the differences in the fluid expulsion process, the initial source fluid, and diagenetic transformation.

The objective of this work was to study the chemical nature of cold seep fluids, and to assess whether rapid measurements of chemical concentrations in the pore fluids of surficial sediment could be used to fingerprint the initial fluid source and process driving fluid expulsion. The ions silicate (Si), sulfide $\left(\mathrm{S}^{2-}\right)$, iron $\left(\mathrm{Fe}^{2+}\right)$, and manganese $\left(\mathrm{Mn}^{2+}\right)$ were measured using in situ chemical analysis at known cold seep sites. The concentration of these ions were compared between sites for active seep regions and within sites for concentrations determined inside and outside active seep regions. 


\section{COLD SEEPS}

Cold seep ecosystems were discovered in the 1980s in geologically active areas of coastal regions (Kulm et al., 1986; Suess et al., 1985). Seep localities are associated with surface venting of fluids caused by geological processes, such as tectonically induced compression (Suess et al., 1985; Suess and Whiticar, 1989), and hydrocarbon seepage (Kennicutt et al., 1989), which drive pore waters rich in reduced ions from deep sediments via existing conduits.

Seeps are also located on passive margins where geological activity is not evident. Catastrophic erosion (exposing reduced ions buried in ancient organic rich sediments; Mayer et al., 1988), aquifer forcing (Cary et al., 1989; Paull et al., 1984), and rapid sedimentation are hypothesized methods of seep generation. Recently, the dissolution of clathrates due to uplift and erosion has been proposed as an additional method of fluid expulsion in seep systems (Martin et al., submitted; Stakes et al., submitted; Tsunogai et al., 1996). In areas where fluid seepage is not evident, Smith et al. (1989) suggests microbial utilization of organic rich material (e.g., whale carcasses or sunken wood) provides sufficient reduced sulfide to support small chemosynthetic communities. The study of cold seep ecosystems remains limited at this time, with published material available on only a few sites (Table 1). Research has focused on the structure and size of biological communities, basic geologic features, and basic biogeochemistry.

A primary characteristic of cold seep systems is the presence of chemosynthetic organisms similar to those of hydrothermal vent biological communities. The faunal composition, of cold seeps in the Monterey Bay region, is typically simple in structure, maintaining a few macrofaunal species at each site (Barry et al., submitted a; Embley et al., 1990; Mayer et al., 
Table 1. Cold seep sites and publications referenced.

\begin{tabular}{cc}
\hline Cold Seep Location & Study \\
\hline Oregon Subduction Zone & $\begin{array}{c}\text { Suess et al., 1985 } \\
\text { Suess and Whiticar, 1989 }\end{array}$ \\
Monterey Bay, California & $\begin{array}{c}\text { Barry et al., submitted a, b } \\
\text { Embley et al., 1990 }\end{array}$ \\
Japan Subduction Zone & $\begin{array}{c}\text { Orange, 1993, 1994, submitted a, b } \\
\text { Stakes et al., submitted }\end{array}$ \\
Boulègue et al., 1987 \\
Fiala-Médioni et al., 1993 \\
Juniper and Sibuet, 1987 \\
Masuzawa et al., 1992
\end{tabular}

1988). Barry et al. (submitted a) have compiled a comprehensive list of organisms inhabiting selected cold seeps within the Monterey Bay region. The principal obligate chemosynthetic organisms are the bacteria Beggiatoa sp., the bivalve Calyptogena sp., and the gastropod Mitrella permodesta. Tube 
worms, common in East Pacific Rise hydrothermal vent ecosystems, are rare in the cold seeps of the Monterey Bay region (Barry et al., submitted a) although Embley et al. (1990) found dense Polybrachia sp. patches in the Ascension Fan Valley west of the Monterey Bay. The bivalve Solemya sp. occurs rarely at cold seep sites of the region (Barry et al., submitted a; Embley et al., 1990), although their population may be underestimated because they live below the sediment surface.

The foundation of the biological community is chemosynthetic bacteria which utilize reduced ions, principally sulfide $\left(S^{2-}\right)$, as their energy source to fix carbon dioxide $\left(\mathrm{CO}_{2}\right)$, water $\left(\mathrm{H}_{2} \mathrm{O}\right)$, and nitrate $\left(\mathrm{NO}_{3}{ }^{-}\right)$into essential organic substances (Hessler and Kaharl, 1995; Jannasch, 1995). An environment suitable for chemosynthetic organisms may be created when overpressured fluids are channeled to the sediment-water interface carrying reduced ions from deep sediments (Embley et al., 1990).

The chemosynthetic physiology of hydrothermal vent organisms has been well studied (see reviews by Jannasch 1983 and 1989). The reactions that are used to provide energy are "chemoautolithotrophic," using inorganic materials as their carbon and electron source (Jannasch, 1989, 1995; Libes, 1992). The principal chemosynthetic reactions (Jannasch, 1995) involve the oxidation of sulfide $\left(S^{2-}\right)$ by oxygen:

$$
\mathrm{H}_{2} \mathrm{~S}+2 \mathrm{O}_{2} \longrightarrow \mathrm{H}_{2} \mathrm{SO}_{4}
$$

This has a $\Delta G^{\circ}$ of $-706 \mathrm{~kJ} \cdot \mathrm{mol}^{-1}$. The subsequent reduction of carbon dioxide $\left(\mathrm{CO}_{2}\right)$ to organic carbon by:

$$
\mathrm{CO}_{2}+\mathrm{H}_{2} \mathrm{~S}+\mathrm{H}_{2} \mathrm{O}+\mathrm{O}_{2} \longrightarrow\left[\mathrm{CH}_{2} \mathrm{O}\right]+\mathrm{H}_{2} \mathrm{SO}_{4}
$$

has a $\Delta G^{\circ}$ of $-211 \mathrm{~kJ} \cdot \mathrm{mol}^{-1}$. The $\mathrm{CO}_{2}$ reduction reaction acquires essential free energy from the biochemically linked and enzymatically catalyzed sulfide 
oxidation reaction (Jannasch, 1995). Both reactions are aerobic, requiring oxygen which is sufficiently abundant in sea water.

The reduced ion sulfide $\left(S^{2-}\right)$ is not a ubiquitous feature of interstitial fluids of deep ocean sediments. Sulfide is generated though a series of redox reactions involving the oxidation of organic material in buried sediments when anoxic conditions develop. Sufficient organic material, to produce anoxic conditions, is only produced near the continental margins and other areas of high productivity (Hedges and Keil, 1995). Fauna associated with cold seeps, therefore, are found only at ocean margins and are not likely to occur in abyssal plains.

Diagenesis is the chemical and physical processes that modify buried sediments and produces the reduced compound needed for chemosynthetic organisms. It generally follows a prescribed sequence of redox reactions depending on the conditions and constituents of the sediments (Claypool and Kaplan, 1974; Froelich et al., 1979; Libes, 1992; Stumm and Morgan, 1981). The reaction utilized to oxidize organic matter will, theoretically, be the most efficient reaction possible for the environment and thus be controlled by the amount of free energy liberated by the reaction (Table 2). Aerobic respiration (Equation 3, in Table 2) is the most energy producing oxidation and will proceed until oxygen is no longer available. Oxidation by manganese oxide $\left(\mathrm{MnO}_{2}\right)$, nitrate $\left(\mathrm{NO}_{3}{ }^{-}\right)$, and iron oxide $\left(\mathrm{FeO}_{x}\right)$ proceeds in suboxic environments created by the depletion of $\mathrm{O}_{2}$ in aerobic respiration (Equations 4-6, in Table 2$)$. Oxidation by sulfate $\left(\mathrm{SO}_{4}{ }^{2-}\right)$ becomes the dominate reaction in anoxic conditions that are relatively free of $\mathrm{MnO}_{2}$ and $\mathrm{NO}_{3}^{-}$(Equation 7, in Table 2). This cascading sequence of reactions develops anomalous concentrations of the reduced ions $\mathrm{Mn}^{2+}, \mathrm{NO}_{2}^{-}, \mathrm{NH}_{4}^{+}, \mathrm{Fe}^{2+}$, and $\mathrm{S}^{2-}$ at different 
depths of sediments (Figure 1). Studies of sulfur, manganese, and iron cycling in marine sediments often show simultaneous reduction of manganese and iron (Figure 2a; Froelich et al., 1979), while Thamdrup, Fossing, and Jørgensen (1994) show distinct separation of the manganese and iron reduction zones (Figure 2b).

Table 2. Redox reactions of organic matter. Free energy $\Delta G^{\circ}=\mathrm{kJ} / \mathrm{mol}$. (Adapted from Froelich et al., 1979, Geochimica et Cosmochimica Acta, Vol. 43, p. 1076).

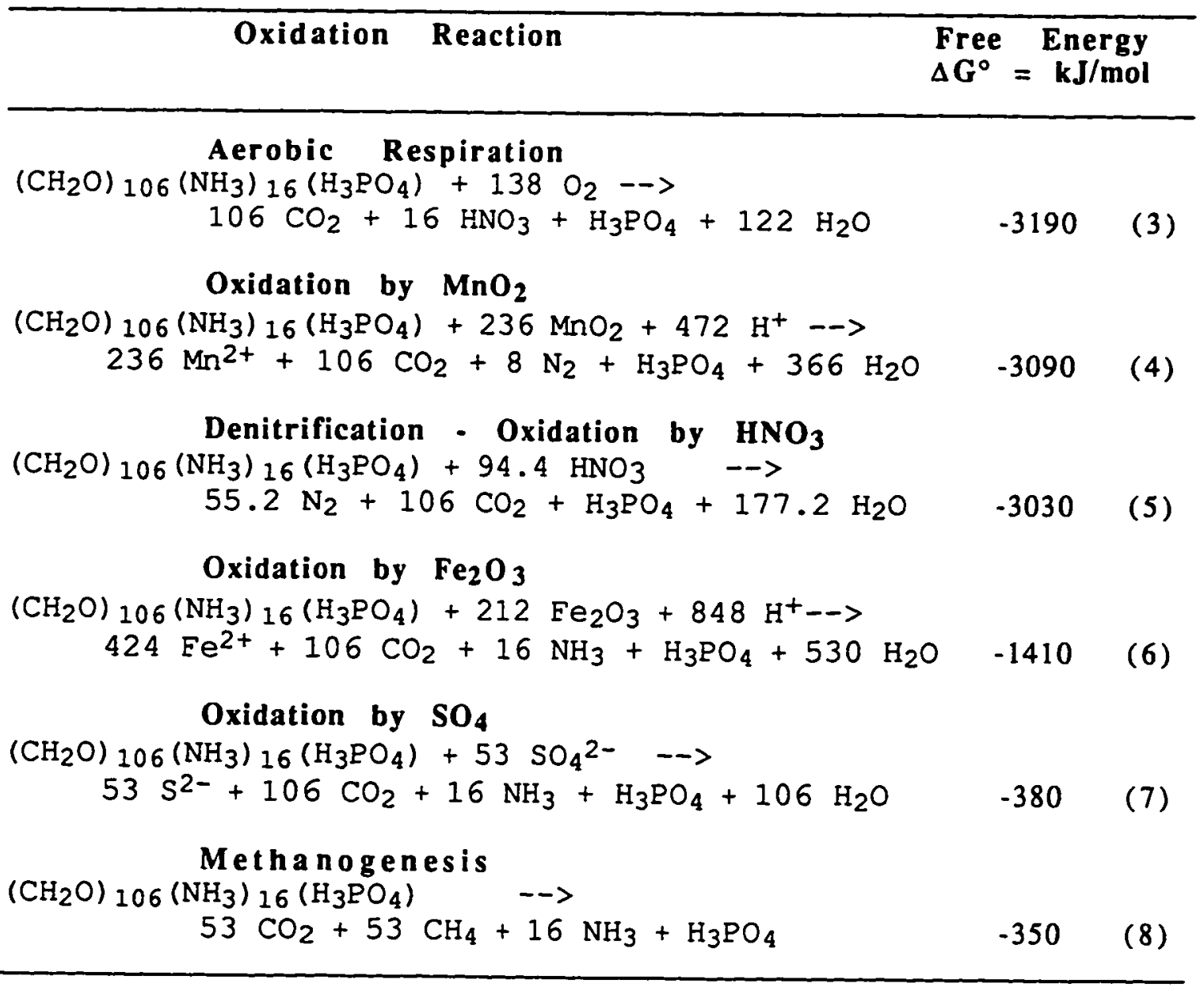




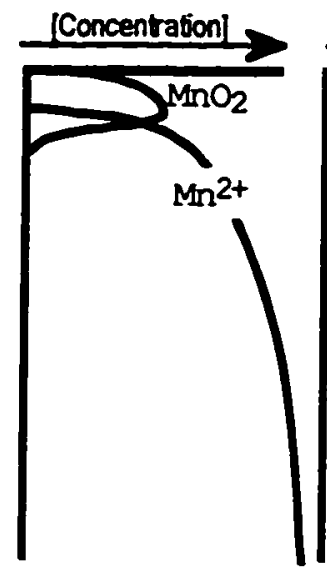

(a)

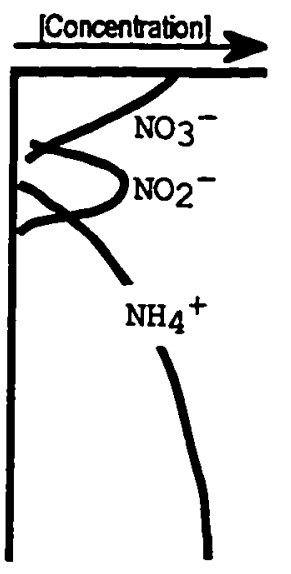

(b)

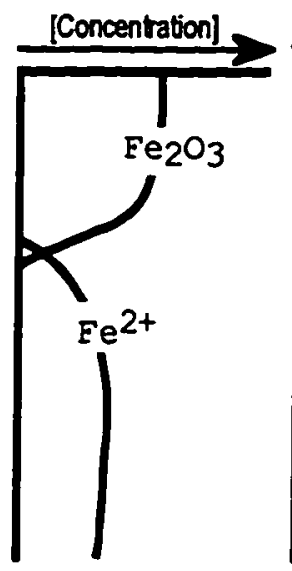

(c)

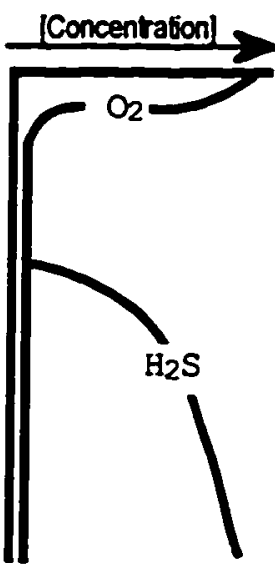

(d)

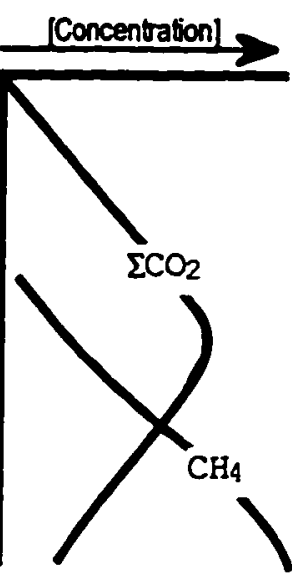

(e)

Figure 1. Idealized depth profiles of manganese, nitrogen, iron, sulfur, and methane. (a) $\mathrm{MnO}_{2}$ and $\mathrm{Mn}^{2+}$, (b) $\mathrm{NO}^{3-}, \mathrm{NO}^{2-}$, and $\mathrm{NH}^{4+}$, (c) $\mathrm{Fe}_{2} \mathrm{O}_{3}$ and $\mathrm{Fe}^{2+}$, (d) $\mathrm{O}_{2}$ and $\mathrm{H}_{2} \mathrm{~S}$, and (e) $\Sigma \mathrm{CO}_{2}$ and $\mathrm{CH}_{4}$. (Adapted from S. M. Libes, 1992, An Introduction to Marine Biogeochemistry, p. 194.)

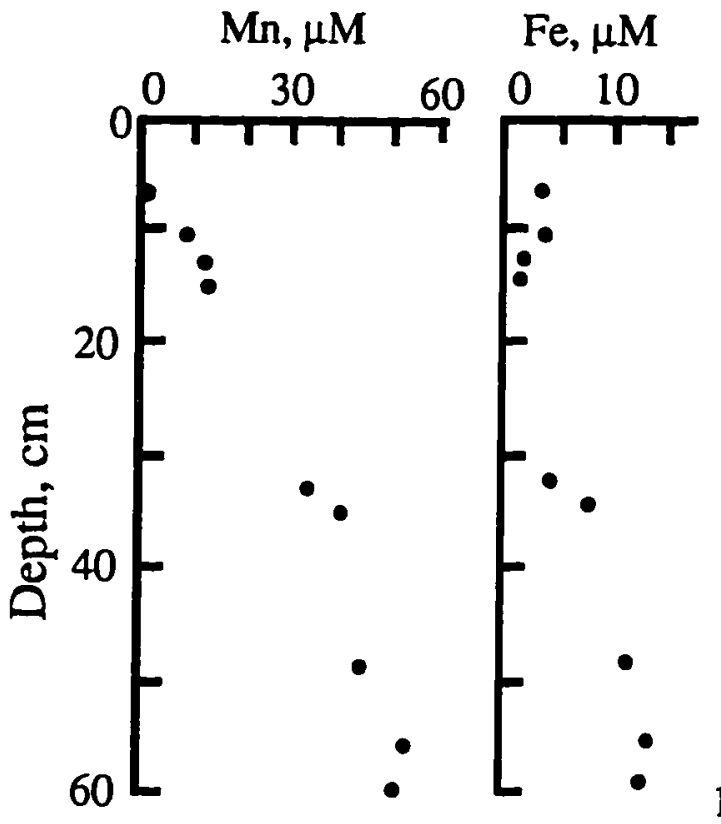

(a)

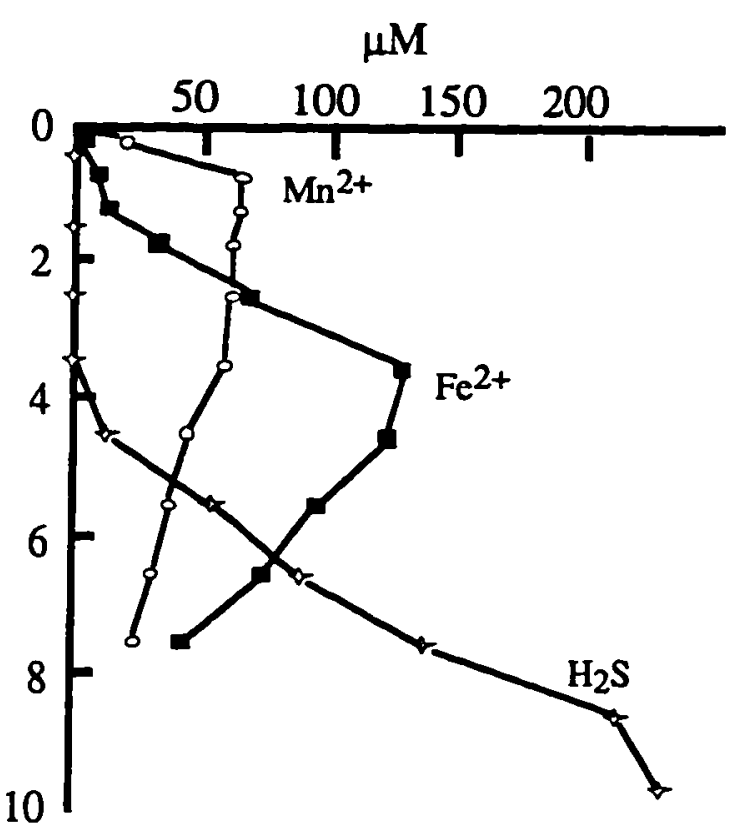

(b)

Figure 2. Pore water profiles of manganese and iron. (a) $\mathrm{Mn}$ and Fe from suboxic eastern equatorial Atlantic sediments showing coexisting manganese and iron reduction zones (Froelich et al., 1979). (b) $\mathrm{Mn}^{2+}, \mathrm{Fe}^{2+}$, and $\mathrm{H}_{2} \mathrm{~S}$ from coastal marine sediment of Aarhus Bay, Denmark, showing distinct manganese and iron reduction zones (Thamdrup, Fossing, and Jørgensen, 1994). 
Methanogenesis, the production of methane by the decomposition of organic material through microbial metabolism (Equation 8, in Table 2) is another important diagenetic reaction. Microbial generation of methane takes place below the sulfate reduction zone (Figure 1) in anoxic conditions (Claypool and Kaplan, 1974). Martens and Berner (1974) suggest that sulfate is toxic to methanogenic bacteria and it precludes the development of methane in the sulfate reduction zone.

Methane is also developed in deep sediments ( 1 to $3 \mathrm{~km}$ ) by the thermocatalytic reactions known as catagenesis (Libes, 1992). Increased pressure and temperature $\left(50^{\circ}\right.$ to $150^{\circ} \mathrm{C}$ ) induce short chained hydrocarbons (e.g., butane and ethylene) to break away from complex organic molecules (e.g., fulvic acids, humic acids, carbohydrates, proteins, and lipids) forming low to medium weight hydrocarbons. Methane, carbon dioxide, and graphite are produced instead of medium weight hydrocarbons when catagenesis proceeds at temperatures exceeding $100^{\circ} \mathrm{C}$ and/or proceeds for extensive reaction times. Large deposits of organic material are capable of generating gaseous methane and hydrocarbons that are less dense than sea water.

The ions utilized as the primary energy source by chemosynthetic organisms are thus generated in organic-rich sediments typical of coastal regions. Coastal waters and regions of upwelling have high concentrations of nutrients that support large phytoplankton communities. A portion of the phytoplankton will drift to the ocean floor creating sediment with high organic content. Diagenetic processes break down organic material via aerobic respiration creating an anaerobic environment. Anacrobic sediments support the production of reduced ions (e.g., $\mathrm{S}^{2-}, \mathrm{Fe}^{2+}$, and $\mathrm{Mn}^{2+}$ ) utilized by chemosynthetic organisms. However, the depth at which these ions are 
generated are often deeper than the macrofauna are capable of reaching (Figure 3). Thus, a physical and/or geological process must function to move the interstitial fluids rich in reduced ions within the reach of the chemosynthetic community.

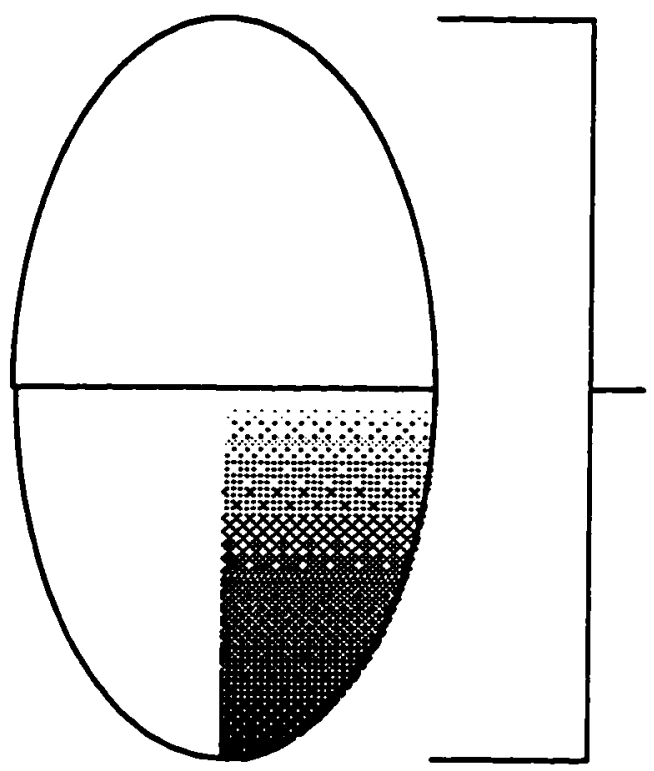

Clam maximum length:

C. pacifica to $65 \mathrm{~mm}$

C. kilmeri to $120 \mathrm{~mm}$

Live clams bury themselves about $1 / 2$ of the total clam shell length into sediments

Sulfide must be within $65-120 \mathrm{~mm}$ of sediment surface

Figure 3. Diagram of the position Calyptogena sp. resides in sediments. Approximately $1 / 2$ the length of the clam is buried below sediments (Barry et al., submitted a) with the clam foot extending an additional $1 / 3$ to $1 / 2$ the body length beyond the lower edge of the clam shell.

\section{INTERSTITIAL SILICA}

Elevated concentrations of dissolved silica, relative to concentrations in bottom water, are found in all marine sediments. The elevated silica provides a tracer ion for fluid flow because it quickly reaches a maximum concentration that does not change much with depth in sediment (Figure 4). Suess (1979) suggests that silica dissolves at constant proportions "relative to the other 
remineralization constituents", thus giving it a constant concentration ratio with other non-reactive interstitial constituents (p. 344).
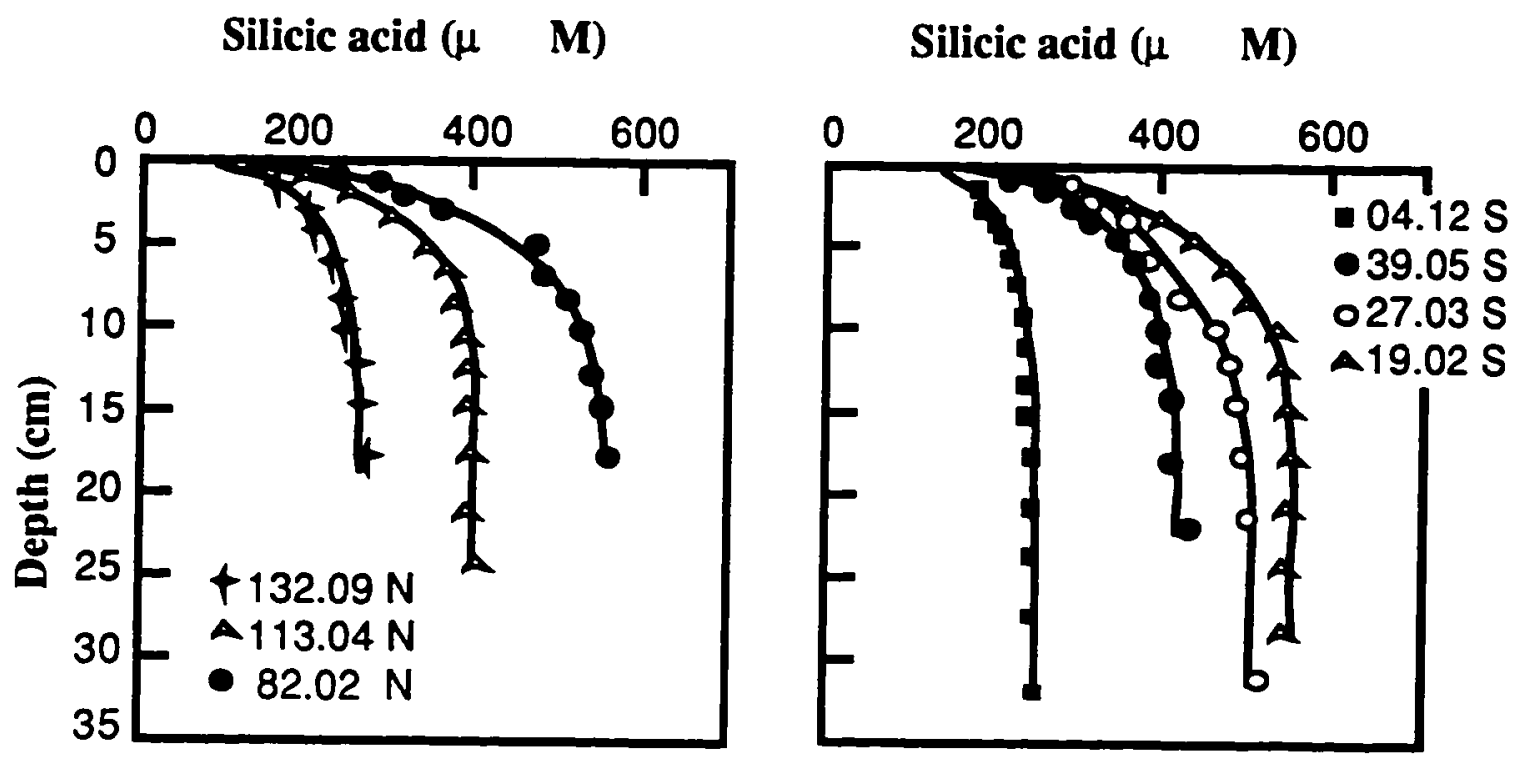

Figure 4. Typical pore water profile of silicic acid. Samples were taken along a transect at longitude $140^{\circ} \mathrm{W}$ in the southern and northern hemisphere during the PACFLUX II cruise. The latitude of each station is indicated on the above graphs. Adapted from McManus et al., 1995.

Silicic acid $\left(\mathrm{H}_{4} \mathrm{SiO}_{4}\right)$ is the dominant species of dissolved silica in sea water, ranging from $1 \mu \mathrm{M}$ in surface waters to $150 \mu \mathrm{M}$ at water depths down to $2000 \mathrm{~m}$ (Libes, 1992). The source of silicic acid in sediments is the dissolution of biogenic opal (solid phase silica) deposited in sediments from siliceous tests of phytoplankton and protozoans (Berelson et al., 1990; DeMaster, 1981; McManus et al., 1995). Berelson et al. (1987) reports that about $90 \%$ of biogenic opal is recycled into the water column. The opal which is not recycled is quickly dissolved into the interstitial waters, increasing the concentration from ambient sea water levels to a maximum concentration controlled by several 
processes. It is speculated that the concentration of dissolved silica depends on the deposition rate of biogenic opal, the solubility of the available opal, and the development of surface coating which preserves opal (McManus et al., 1995). Maximum concentrations of silica in sediments, slightly south of the Monterey Bay region, were determined by Moss Landing Marine Laboratories during the Teflon-95 cruise range to from 350 to $660 \mu \mathrm{M}$ (Johnson, unpublished results, 1996). Although the sites sampled on the Teflon-95 cruise do not correspond to the locations of this study, the sites have similar depths and I therefore assume that silicate concentrations would be similar. Teflon95 station $5\left(36^{\circ} 06^{\prime} \mathrm{N}-121^{\circ} 48^{\prime} \mathrm{W}\right)$ at 1390 meters has a maximum silicate concentration of $557 \mu \mathrm{M}$, station $6\left(35^{\circ} 12^{\prime} \mathrm{N}-121^{\circ} 18^{\prime} \mathrm{W}\right)$ at 670 meters has a maximum silicate concentration of $560 \mu \mathrm{M}$, and station $7\left(35^{\circ} 12^{\prime} \mathrm{N}-121^{\circ} 06^{\prime} \mathrm{W}\right)$ at 396 meters has a maximum silicate concentration of $544 \mu \mathrm{M}$ (Figure 5). Higher concentrations of dissolved silica may be found in anoxic sediments, but these higher concentrations are probably due to higher deposition rates of biogenic opal (Hammond, personal communication).

Silicate concentrations in groundwater may vary enormously from the values found in coastal marine sediments. The United States Geological Survey (USGS) Water Resources Report CA-94-2 reported 183 to $283 \mu \mathrm{M}$ silicate in the Salinas River at Chular and $63 \mu \mathrm{M} \mathrm{SiO} 2$ in the Pajaro River Basin for the 19931994 season (Ayers et al., 1994). Two fresh water samples were tested for silicate in an effort to determine likely silicate concentrations for submarine springs in the Monterey Bay region. Sample 1 was collected from a well approximately 5 miles north-east of Santa Cruz and contained $2,200 \pm 100 \mu \mathrm{M}$ silicate. Tap water collected at MBARI, which is from an aquifer in the Salinas Valley, contained $1,900 \pm 100 \mu \mathrm{M}$ silicate. 

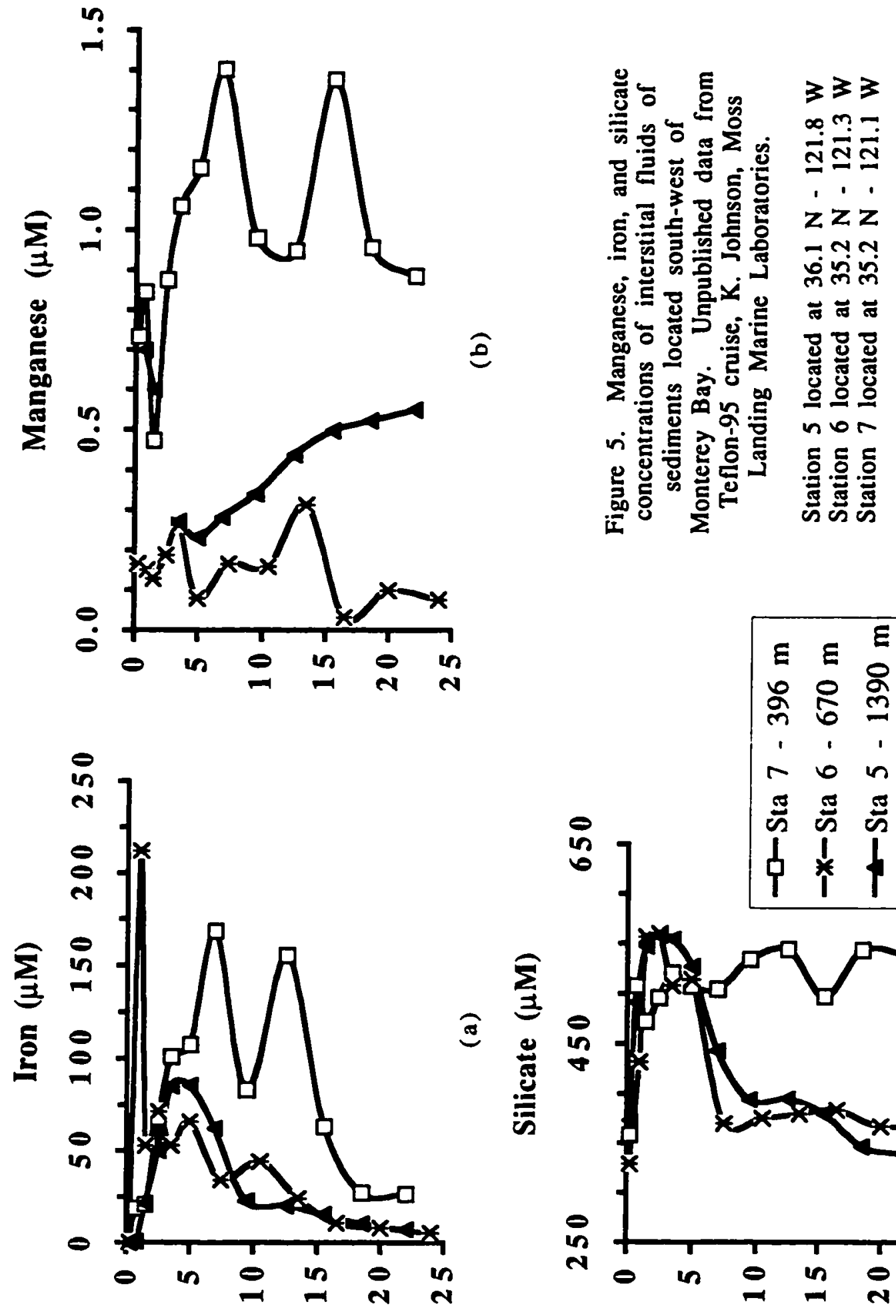

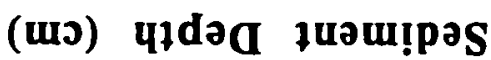

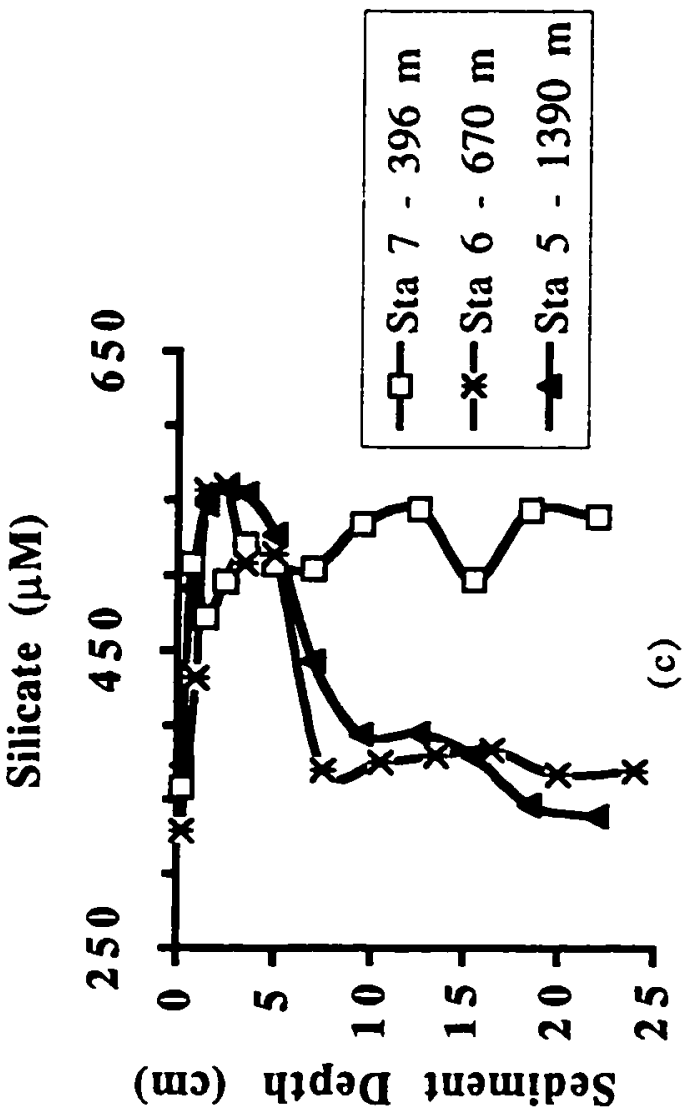




\section{INTERSTITIAL REDUCED IONS}

The reduced ions sulfide $\left(\mathrm{S}^{2-}\right)$, manganese $\left(\mathrm{Mn}^{2+}\right)$, and iron $\left(\mathrm{Fe}^{2+}\right)$ are products of redox reactions (Table 2). Interstitial concentrations depend on available source materials (i.e., sulfate, manganese oxides, and iron oxides) and redox conditions. Additionally these ions react with each other, thus their concentrations are dependent upon the reactive abundance of each ion.

\section{Interstitial Sulfide}

Sulfide concentrations are limited by the availability of organic material and sulfate for the reaction oxidizing organic matter (Equation 7, in Table 2) in anoxic sediments. The sulfate source in interstitial fluids is sea water buried during sediment deposition. Sea water contains approximately $29 \mathrm{mM}$ sulfate (Libes, 1992). There is a one-to-one relationship between the source sulfate and product sulfide (Equation 1), which establishes a maximum calculated value for sulfide of $29 \mathrm{mM}$. In contrast, fresh waters have much less sulfate. Isolated groundwater wells of the Monterey Bay region have been found to contain a maximum level of $1 \mathrm{mM}$ sulfate, although typical values of sulfate are well below detection limits (Muir, 1977). The lower levels of available sulfate in fresh waters would limit sulfate and sulfide concentrations in aquifer-based seeps to $1 \mathrm{mM}$.

\section{Interstitial Iron}

Sediments are enriched with iron oxides (i.e., $\mathrm{Fe}_{2} \mathrm{O}_{3}$ and $\mathrm{FeOOH}$ ) from weathered material deposited through fluvial input or atmospheric deposition (Leslie et al., 1990). Iron oxides are easily reduced in suboxic sediments producing $\mathrm{Fe}^{2+}$ (Equation 6, in Table 2). The availability of iron oxides is hypothetically unlimited. The concentration of interstitial reduced iron measured in suboxic sediments, where sulfate reduction had not occurred, 
ranged from 85 to $210 \mu \mathrm{M}$ (Figure 5; Johnson, unpublished data, 1996). However, in sediments with sulfide, reduced iron concentrations appear to be controlled by the precipitation of iron sulfide in the form of pyrite (FeS) or greigite ( $\mathrm{Fe}_{3} \mathrm{~S}_{4}$; Leslie et al., 1990). The solubility of iron sulfide minerals is extremely low (Emerson, Jacobs, and Tebo, 1983). In the presence of high sulfide concentrations (greater than $1 \mu \mathrm{M}$ ), dissolved iron may be limited to concentrations of less than $1 \mathrm{nM}$. Production of large amounts of sulfide will titrate all of the reduced iron and render it undetectable in pore waters.

Fresh aquifer water, of the Monterey Bay region, has dissolved iron concentrations as high as $2 \mathrm{mM}$ (Muir, 1977). Aquifer waters of the region also have low concentrations of sulfate and support little sulfide production. Dissolved iron can reach much higher levels than it can in typical marine sediments due to the excess of iron relative to potential sulfide sources.

\section{Interstitial Manganese}

Manganese oxides from weathering of subaerially exposed rock provide the source material for reduced $\mathrm{Mn}^{2+}$ in buried suboxic to anoxic sediments (Froelich et al., 1979; Lynn and Bonatti, 1965; Pedersen and Price, 1982). Wilson et al. (1986) demonstrated that $\mathrm{Mn}^{2+}$ diffuses upward to areas of oxygen penetration where it is precipitated as $\mathrm{Mn}_{3} \mathrm{O}_{4}$, developing a region enriched with manganese oxide. Further sedimentation will bury enriched layers, moving them into increasingly reducing environments, producing waters with high dissolved $\mathrm{Mn}^{2+}$. Reduced manganese precipitates with sulfide but the solubility of $\mathrm{MnS}$ is not as low as that of FeS (Emerson, Jacobs, and Tebo, 1983) and the concentration of $\mathrm{Mn}^{2+}$ is likely controlled by the precipitation of rhodochrosite $\left(\mathrm{MnCO}_{3}\right)$ :

$$
\mathrm{Mn}^{2+}+\mathrm{CO}_{3}^{2-} \longrightarrow \mathrm{MnCO}_{3}
$$


The concentration of $\mathrm{Mn}^{2+}$ in sediments is therefore determined by the concentration of the $\mathrm{CO}_{3}{ }^{2-}$ ion. The concentration of interstitial reduced manganese measured in suboxic sediments during the Teflon-95 cruise ranged from 0.3 to $1.4 \mu \mathrm{M}$ (Figure 5; Johnson, unpublished data, 1996).

\section{GEOLOGIC SETTING}

The Monterey Bay region, positioned approximately $115 \mathrm{~km}$ south of San Francisco along the coast of central California, is the location of this study (Figure 6). The mouth of the crescent shaped embayment extends some $37 \mathrm{~km}$ from Point Santa Cruz in the north to Point Piños in the south. A characteristic feature of the Monterey Bay area is the extensive network of submarine canyons (Figure 7) that define the topography of the sea floor. A variety of geologic features associated with the canyon that are important settings for cold seeps.

The Monterey Canyon system is the dominant submarine feature of the Monterey Bay region. It extends $90 \mathrm{~km}$ westward and $2 \mathrm{~km}$ southward from the canyon head at Moss Landing cutting deeply into the continental shelf, slope, and abyssal plane (Greene, 1977). Monterey Canyon is a v-shaped channel that meanders across the continental shelf and upper continental slope connecting with the Monterey trough of Martin (1964), which is a u-shaped continuation of the canyon. The West and East Channels are extensions of the trough into two $v$-shaped sediment filled canyons that merge at latitude $35^{\circ} 48^{\prime}$ $\mathrm{N}$ and longitude $123^{\circ} 01^{\prime} \mathrm{W}$ (Martin, 1964) and terminates in the Monterey Fan Valley. Monterey Canyon is one of the largest submarine canyons in the world, comparable to the Grand Canyon of Arizona in length, height, and span 


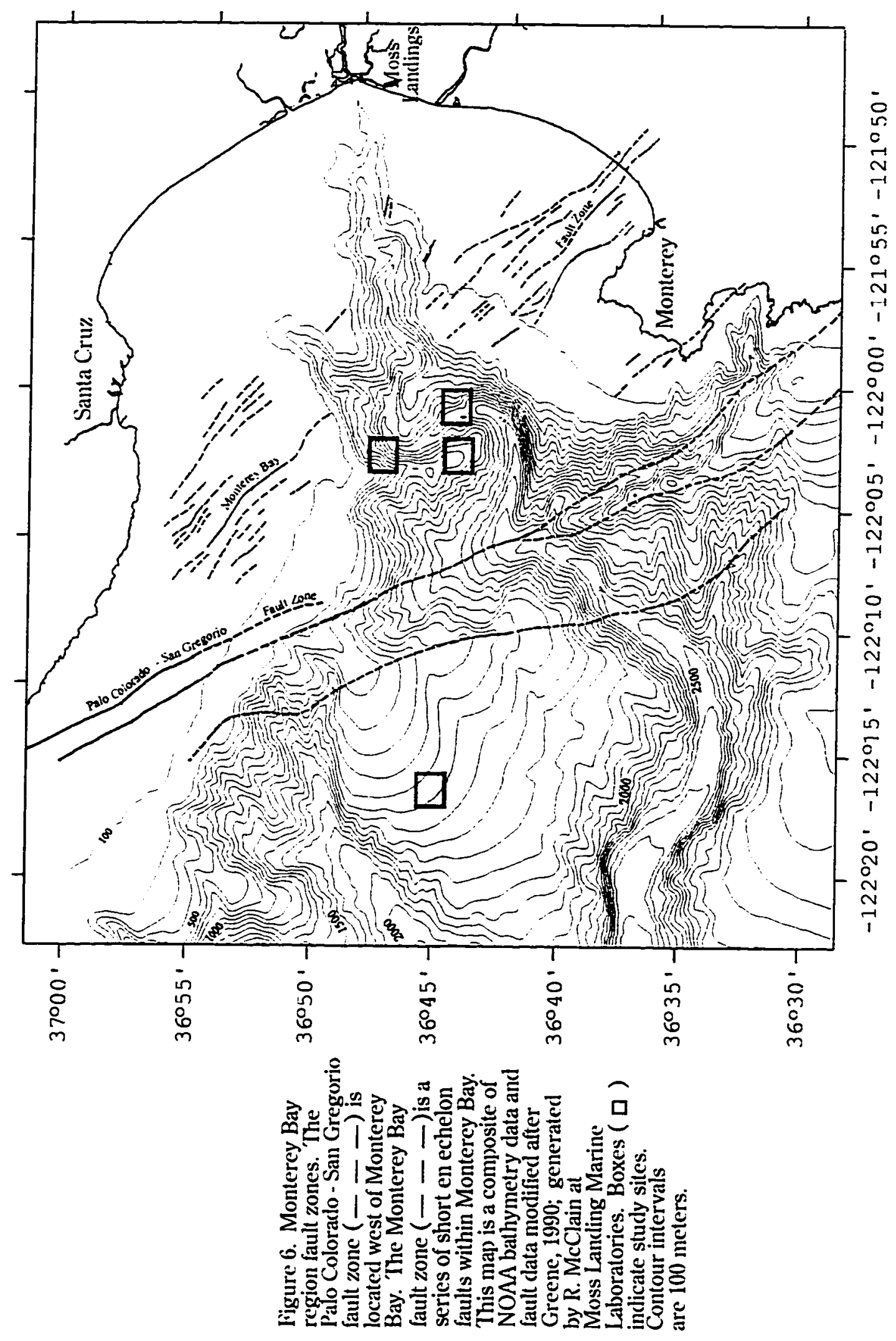




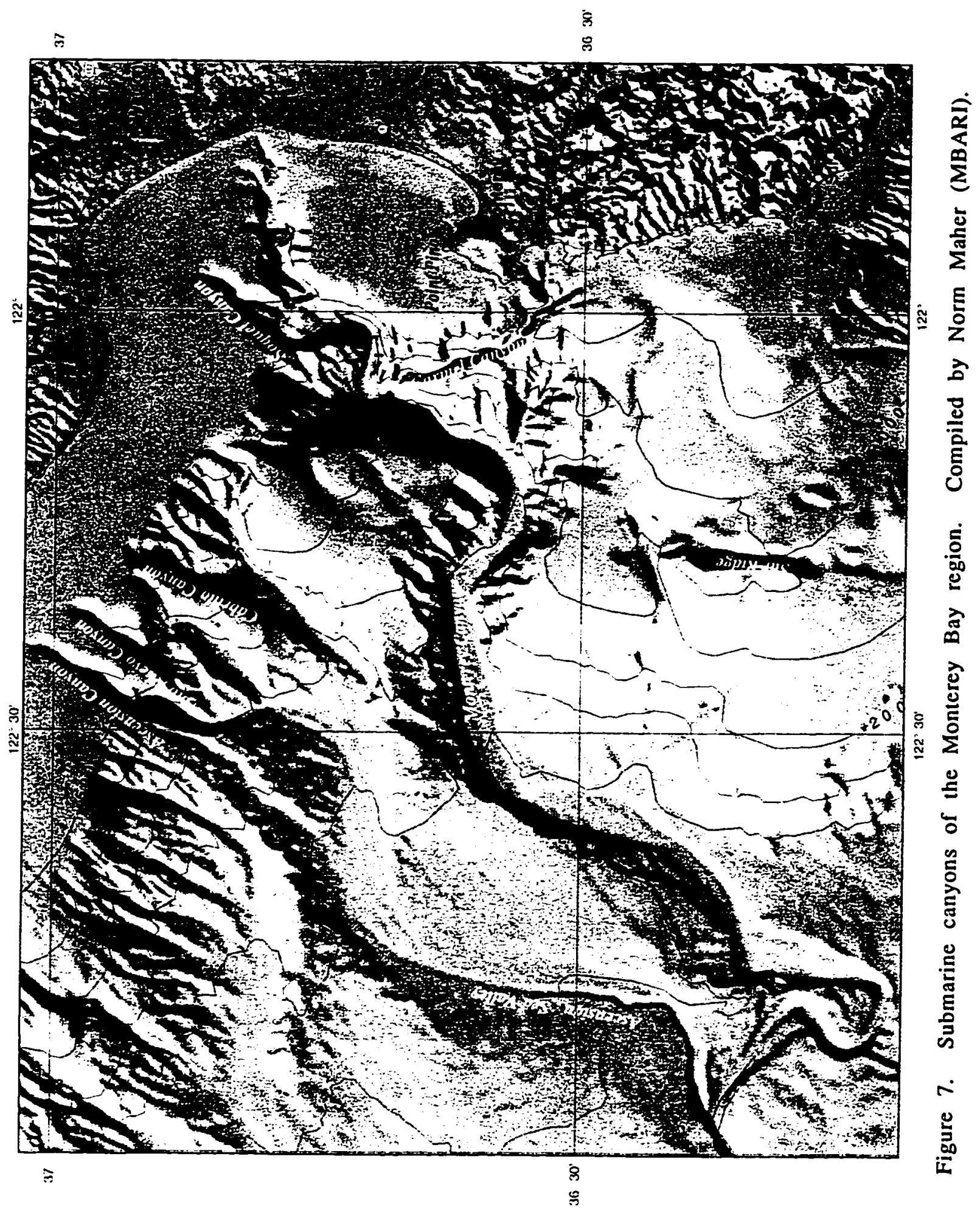


(Shepard, 1963). The presence of a deeply buried gorge near the mouth of Elkhorn Slough led to the speculation that an ancient canyon was cut by drainage of the Great Valley of California and that the Monterey Canyon is a reexcavation of the original gorge (Greene, 1977; Shepard, 1973; Starke and Howard, 1968).

Monterey Canyon and Fan Valley are joined by two major tributaries, the Soquel, and Carmel Canyons and their associated systems (Greene and Hicks, 1990). The Ascension Canyon system, located on the continental slope some 35 km northwest of Santa Cruz, joins the Monterey Fan Valley at the depth of 3300 m (Greene, 1977).

The Soquel Canyon, one of the smallest canyons of the system, joins the Monterey Canyon, at the depth of 915 meters of water, $18 \mathrm{~km}$ southwest of its origin which is about $11 \mathrm{~km}$ southeast of Santa Cruz, (Greene, 1977; Martin, 1964; Sullivan, 1994). The exposed rocks of the Soquel Canyon are primarily sandstones of the Purisima Formation, which is an important aquifer in the northern Monterey Bay region (Greene, 1970; Sullivan, 1994).

One head of the Carmel Canyon is located at the mouth of the San Jose Creek, about $12 \mathrm{~km}$ south of Monterey Bay (Martin, 1964; Greene, 1977). Carmel Canyon achieves maximum relief of approximately 1800 meters where it intersects Monterey Canyon $30 \mathrm{~km}$ northwest (Greene, 1977; Martin, 1964).

West of Monterey Bay, the Ascension-Monterey canyon system terminates in the Ascension and Monterey Fan valleys at the base of the continental slope (Embley et al., 1990; Greene, 1990). This region is characterized by sediment fans at the mouths of terminating canyons (Embley et al., 1990) and gently sloping terrain of smooth brown sediments. Distinctive features in the region are a compressional ridge (Greene et al., 1993; Orange et al., submitted a), 
authigenic carbonates (Greene et al., 1993; Orange et al., submitted a; Reed, McHugh, and Ryan, 1992), and rare pock marks (Orange et al., submitted a). Uplift of the region, suggested by the abandonment of an early channel, may be the result of compression associated with movement of the North American and Pacific plates (Atwater, 1970; Barry et al., submitted a; Greene et al., 1993).

Side scan sonar of the region revealed large (200 m diameter) elliptical features of high reflectivity, which was determined to be carbonate. Carbonate precipitation is dependent upon the presence of methane $\left(\mathrm{CH}_{4}\right)$ developed by biogenic and/or thermogenic sources. The elliptical nature of the carbonate structures and occasional pockmarks found on the sediment surface suggests large pockets of methane gas escaped to the sediment-water interface in the region (Greene et al., 1993; Orange et al., submitted a). Martin et al. (submitted) suggest a combined thermogenic and biogenic methane source.

\section{FAULTING IN THE MONTEREY BAY REGION}

Faults are important structures in channeling overpressured fluids from depth to support cold seep communities (Barry et al., submitted a; Greene et al., 1993; Orange et al., 1993, submitted a). The Monterey Bay region is dominated by two northwest-trending fault zones, the Palo Colorado-San Gregorio and Monterey Bay, which intersect each other to the north (Figure 6). The narrow (about $3 \mathrm{~km}$ wide) Palo Colorado-San Gregorio fault zone is a minimum of 125 $\mathrm{km}$ long and is defined by one or two main fault strands (Greene, 1977). The Palo Colorado-San Gregorio fault zone comes onshore at Año Nuevo Point and joins the San Andreas fault in the north. The Palo Colorado-San Gregorio fault zone is shown by Greene (1977) to connect with the Palo Colorado fault to the 
south via the Carmel Canyon fault, increasing the overall length of the zone substantially.

The Monterey Bay fault zone (Figure 6), in contrast, is a 10 to $15 \mathrm{~km}$ wide series of short $(66 \%$ less than $1.6 \mathrm{~km}$ in length) northwest-trending en echelon faults terminating to the north where it intersects with the Palo Colorado-San Gregorio fault zone. The Monterey Bay Fault zone dominates the structure of the seafloor from Santa Cruz to Monterey (Greene, 1977). Soquel Canyon is located within the Monterey fault zone (Sullivan, 1994) and the Monterey meander within Monterey canyon is controlled by faulting within the Monterey Bay fault zone. In addition to the two major fault zones of the Monterey Bay region there are several additional fault zones both on and off shore (Greene, 1977, 1990).

The Palo Colorado-San Gregorio fault zone demarcates the western boundary of the granitic Salinian block basement of the Monterey Bay (Greene, 1977. Page, 1970; Rosenberg and Clark, 1994). East of the Palo Colorado-San Gregorio fault zone and in the southern Monterey Bay, the hydrocarbon bearing Monterey Formation directly overlies the granitic basement with the water bearing Purisima Formation directly overlying the Monterey Formation. In the northern region of the Monterey Bay, the Monterey Formation and Purisima Formation are separated by a layer $(570+\mathrm{m})$ of siliceous, organic mudstone and sandstone (Greene, 1977). West of the Palo Colorado-San Gregorio fault zone the basement rock appears to be consolidated to semiconsolidated sedimentary as well as volcanic rocks overlaid by bedded shale, possibly the Monterey Formation or equivalent. The bedded shale is overlain by sandstone and shale which may be the Purisima Formation or equivalent (Greene, 1977). 


\section{FRESH WATER IN SUBMARINE ENVIRONMENTS}

Groundwater can also play an important role in cold seep generation if fresh water springs outcrop in submarine areas. The Monterey Bay is surrounded by 6 ground-water subbasins (Figure 8): The Santa Cruz Coastal, San Lorenzo, Aptos-Soquel, Pajaro Valley, Salinas, and Carmel (Muir, 1977). All subbasins have water-bearing structures that provide fresh water for domestic and agricultural uses. Studies of these subbasins began in 1931 when saltwater intrusion became a problem (Greene, 1970). Less is known of the geology of the water-bearing structures and groundwater movement in the Santa Cruz Coastal, San Lorenzo, Aptos-Soquel, and Carmel basins than in the Salinas and Pajaro Valley basins.

Groundwater recharge is a combination of rainfall and artificial introduction of water to subbasins. Additionally, seepage from Pajaro river and overflow from the Aptos-Soquel subbasin play important roles in the recharge of the Pajaro subbasin (Muir, 1977). Ground-water movement is generally towards Monterey Bay following gravitational forces and hydrostatic head through south and west dipping permeable beds and fractures in impermeable rocks or aquifers that extend to and/or under Monterey Bay (Muir, 1977). The Salinas subbasin contains the Aromas Sand and Pleistocene and Pliocene Paso Robles Formation aquifers (Muir, 1977; Greene, 1970). Salt water intrusion is extensive along the mouth of the Salinas River, especially in the "180-ft" and "400-ft" aquifers, which extend well into Monterey Bay (Greene, 1970). The groundwater in the Carmel subbasin is held 


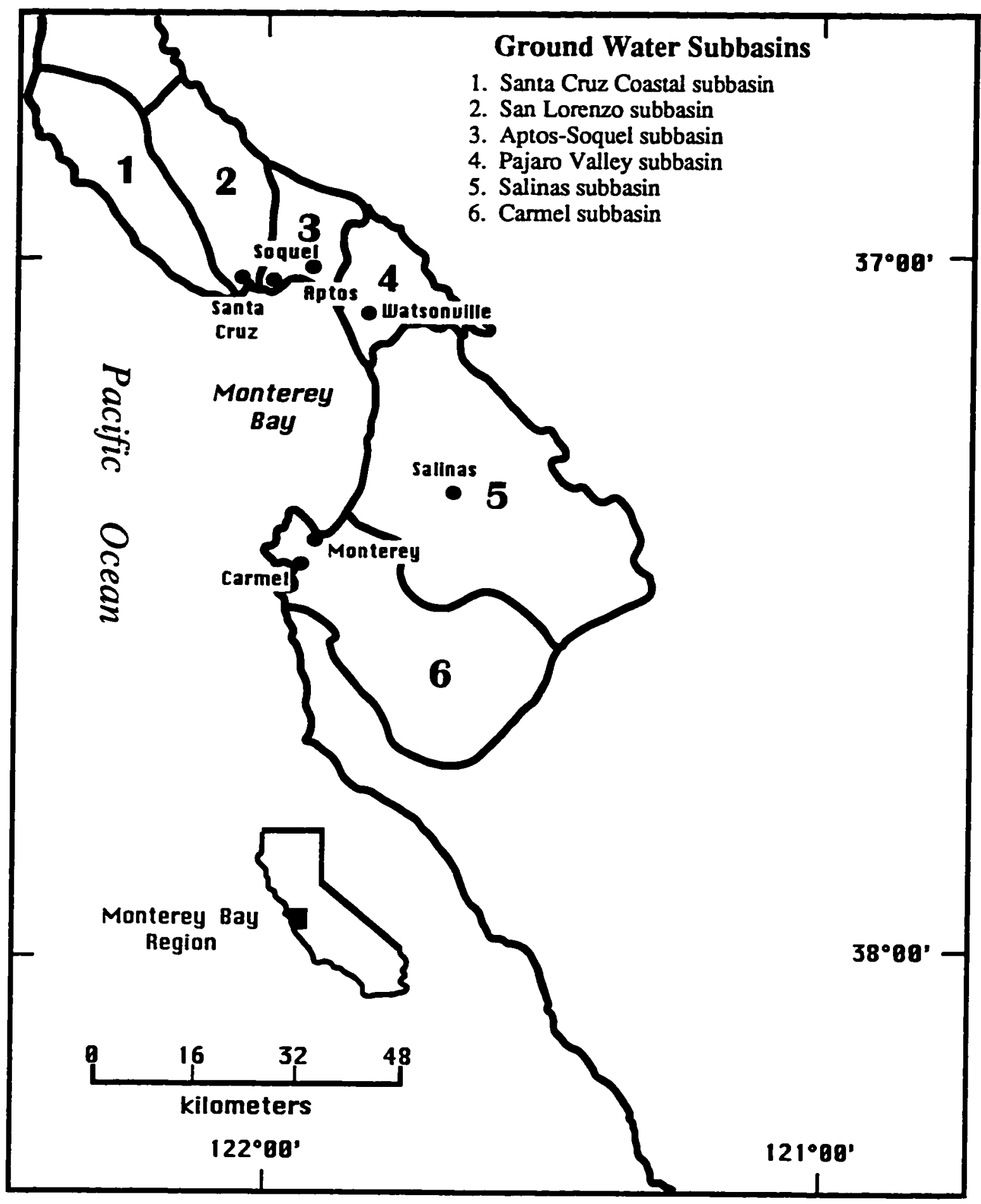

Figure 8. Groundwater subbasins in the Monterey Bay Region. Adapted from Muir 1982, p. 10. 
in alluvium and terrace deposits and moves Northwest towards Monterey Bay (Muir, 1977). High concentrations of dissolved iron $(1 \mathrm{mg} / \mathrm{L})$ and manganese (2 $\mathrm{mM}$ ) are reported from this subbasin (Muir, 1977, 1982).

\section{FLUID EXPULSION METHODS}

This work will examine three geological processes (Figure 9) that can cause an overpressure gradient capable of expelling interstitial fluid from deep sediments. They are: 1) tectonically induced compaction and dewatering, 2) aquifer forcing, and 3) hydrocarbon generation. These processes are found, sometimes working in conjunction, to impel interstitial fluid flow to the sediment surface through fractures and permeable substrates.

\section{Tectonic Compaction and Dewatering}

Tectonic compaction and dewatering develops a pressure gradient by reducing the volume of sediments through compressing the interstice

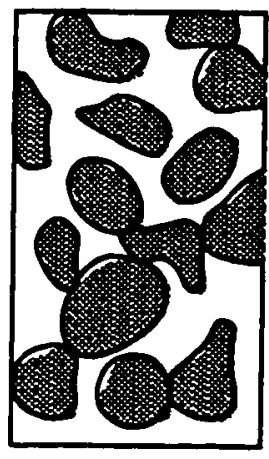

Fluid forced out of sediments

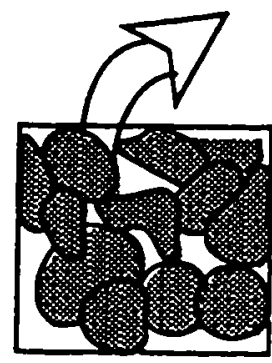

Sediment Grains

Interstitial Fluids

Figure 10. Illustration of sediment compaction. Compaction of sediments reduces interstitial volume requiring fluid expulsion which occurs along fractures and permeable materials.
(Figure 10), forcing the fluids from the sediment. Atwater (1970) describes the Monterey Bay region primarily as a transform fault zone. The Pacific plate is fixed while the North American plate moves southward approximately 6 cm/year (Atwater, 1970; Greene, 1990). Sediments are accreted onto both plates as they move laterally against each other, burying previously deposited sediments and forcing volume loss due to increased weight and physical com- 


\section{FLUID EXPULSION PROCESSES}

Tectonically Induced Compaction
Aquifer Forcing

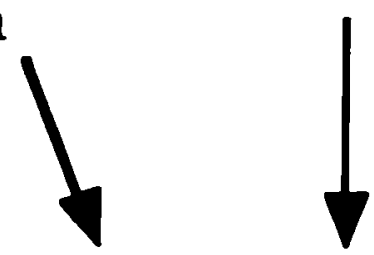

Hydrocarbon Generation (Increased Volume \& Decreased Density)

\section{over pressure}

Pre-existing

Fractures

\section{Fluid movement}

Permeable

Materials

\section{Fluids forced from sediments}

Figure 9. Three fluid expulsion processes capable of creating overpressure and moving fluids to the sediment surface: 1) tectonically induced compaction, 2) aquifer forcing, and 3) hydrocarbon formation. 
pression of the plates as a result of oblique convergence. Crouch, Bachman, and Shay (1984) have also found features in the Monterey Bay that indicate a component of compressional deformation as well as strike-slip motion. Dewatering occurs primarily in areas of tectonic compaction of oblique convergence with less compression and dewatering associated with the motion of strike-slip faults.

Compression and dewatering can also be caused by sediment accumulation due to deposition of marine snow or sediments suspended in water (Embley et al., 1990). Turbidity currents (scdiment density currents) are major erosional and sediment transport phenomena that carry suspended sediments long distances along submarine canyons to depositional sites on submarine fans. The addition of new sediments on old materials causes an increased overburden compressing the older sediments and forcing fluid out of interstitial space. Greene (1977) suggests that sufficient concentration of fluids within submarine canyon walls can destabilize sediments thus creating mass wasting and generating turbidity currents. Slumping causes increased overburden by depositing new sediments onto older material resulting in compression and dewatering.

\section{Hydrocarbon Generation}

Catagenesis, as previously described, generates low and medium weight hydrocarbons at depths of 1 to $3 \mathrm{~km}$ below the sediment surface. Hydrocarbons may be forced from source sediments to migrate along permeable beds until they reach sinks or traps on the surface (Mann, 1990). The process of hydrocarbon migration is thought to be induced by an excess pressure gradient and extensional strain causing hydraulic fracturing and fluid flow 
(Mandl and Harkness, 1987). Mann (1990) lists four factors that contribute to an excess pressure gradient in hydrocarbon generation systems:

1. Increased volume due to transformation of organic matter and generation of hydrocarbons. Ungerer, Behar, and Discamps (1981) and Goff (1983) estimated a 10 to $20 \%$ change in volume by generation of hydrocarbons during laboratory experiments.

2. Overburden, the increased pressure induced by the weight of sediment overlying the area of hydrocarbon generation. Overburden acts in a compressional manner to reduce volume and expel fluid as described in tectonic compression (Figure 10).

3. Thermal expansion of water as described by Barker (1972). Temperature of interstitial fluids increase with the thermal gradient as sediments are pushed deeper with increasing overburden.

4. Clay mineral dehydration, which increases the volume of water in the system.

Increased volume of organic matter during diagenesis (Ungerer and Pelet, 1987) provides a pressure gradient and interstitial fluids move to the sedimentwater interface when hydrostatic pressure is exceeded and a conduit for fluid flow is available. The increased pressure gradient is induced through a decrease in fluid density which generates a buoyant force. Methane and light to medium weight hydrocarbons, dissolve in interstitial Muids decreasing their density and causing them to "float." Additionally, hydrocarbons will separate from interstitial fluids as concentrations increase beyond the solubility of hydrocarbons in sea water. Large volumes of hydrocarbons create large pools of buoyant fluids that generate a region of overpressure capable of exceeding 
hydrostatic. However, Ungerer, Behar, and Discamps (1981) cautions that the volume change pressures are inconsequential unless large quantities of methane gas are generated. A possible alternative method of overpressure generation in these regions is overburden which acts similarly to compression-dewatering as previously discussed, and depends on sedimentation rates. The final two factors that contribute to an overpressure event in hydrocarbon generation regions are clay mineral dehydration and thermal expansion which Mann (1990) considers to have minimal effect.

\section{Aquifer Forcing}

Aquifer forced seeps are generated by artesian springs or groundwater seepage (Kohout, 1966). A pressure gradient, hydraulic head, is produced by elevated source waters in the aquifer (Bowen, 1986; Fetter, 1988). The hydraulic head must exceed the pressure exerted by sea water at the depth of the seep for fluids to flow. Permeable sediments or fractured rock, provide pathways for the fresh aquifer water to exit in submarine regions. Submarine springs have been documented in ancient literature as a source of fresh water (Kohout, 1966). More recently, submarine groundwater discharge has been suspected as a source for eutrophication and coastal water pollution (Vanek and Lee, 1991). Tsunogai et al. (1996) suggested that the fluid source of cold seeps in the Sagami Trough subduction zone is a mixture of sea water, pore water, and groundwater.

Clear evidence of an open conduit between fresh water aquifers and sea water in the Monterey Bay region can be seen in the presence of salt water intrusion in land based wells of the Pajaro Valley and Soquel-Aptos aquifers (Muir, 1980, 1982; Stetson et al., 1973). Sufficiently high pressure gradients in land based aquifers may induce flow in the opposite direction and produce 
submarine springs (Greene, Orange, and Barry, 1993; Greene et al., 1993; Kohout, 1966; Muir, 1980; Vanek and Lee, 1991).

\section{FLUID SOURCE}

Three geological processes that produce cold seeps (tectonic compression, hydrocarbon generation, and aquifer forcing) are hypothesized to have distinct pore water chemistries. Thus, the chemical signature of reduced ions at these sites should be clear and unique. The variations in pore water chemistry are controlled by the composition of the initial fluid source, the history of diagenesis at each site and along migration pathways, and the properties (e.g., mineral content) of the sediments. The four ions studied in this work were sulfide $\left(\mathrm{S}^{2-}\right)$, manganese $\left(\mathrm{Mn}^{2+}\right)$, iron $\left(\mathrm{Fe}^{2+}\right)$, and silicate (Si). The chemistry of these four ions in sediment pore fluids is discussed next, followed by the differences in chemical composition produced by each flow mechanism.

\section{Tectonic Compaction and Dewatering}

The chemical signature of interstitial fluids associated with sediment dewatering in tectonically active areas are dominated by sea water trapped at the time of sedimentation. Modifications to the fluids are due to oxic, suboxic, and anoxic diagenesis at ambient temperatures, 3 to $5^{\circ} \mathrm{C}$ (Table 2), resulting in the reduced species $\mathrm{Fe}^{2+}, \mathrm{Mn}^{2+}, \mathrm{S}^{2-}$, and $\mathrm{CH}_{4}$. Intermediate levels of $\mathrm{s}^{2-}$ are expected due to the high sulfate level of $29 \mathrm{mM}$. found in sea water moderated by the suboxic environment and precipitates of manganese and iron. Development of dissolved iron will be limited to lower concentrations due to precipitation of iron sulfides. $\mathrm{Mn}^{2+}$ may reach quite high levels. Dissolved silicate concentrations depend on the availability of soluble biogenic opal, the 
reactivity of the biogenic silica, and the development of an insoluble coating which isolates silica from the dissolution process (McManus et al., 1995) and is expected to be high ( 300 to $500 \mu \mathrm{M}$ ) but lower than silicate concentrations at aquifer driven sites. Methane is limited to biogenic methane generated below the depth of sulfide generation.

\section{Hydrocarbon Generation and Diagenesis}

Cold seep fluids from hydrocarbon generation sites are expected to originate from diagenesis and thermogenesis of organic materials and ancient sea water buried in deep sediments that are anoxic. High concentrations of sulfide and reduced ions of manganese and iron are produced in the highly reducing environment. Manganese, iron, and sulfide concentrations are limited by the development of iron and manganese carbonate and sulfide precipitates such as $\mathrm{FeCO}_{3}, \mathrm{FeS}, \mathrm{MnS}, \mathrm{MnCO}_{3},(\mathrm{Mn}-\mathrm{Ca}-\mathrm{Mg}) \mathrm{CO}_{3}$ (Froelich, 1979; Murray, Grundmanis, and Smethie, 1978; Pedersen and Price, 1982). Reduced ions of manganese and iron are expected to be low due to the abundance of sulfide that will precipitate into insoluble manganese and iron sulfides. The source for silica is, again, from the deposition of biogenic opals in sediment. Concentrations depend on the reactivity of the source silica and the progression of insoluble coatings (McManus et al., 1995). Silica concentrations are expected to range from 300 to $500 \mu \mathrm{M}$ and be similar to levels found at tectonic compaction cold seep sites. Thermogenic as well as biogenic methane may occur in hydrocarbon charged fluids, depending on the depth of source fluids.

\section{Aquifer Forcing}

Initial fluids at aquifer forced sites are oxygenated fresh water originating from meteoric charged strata such as the Purisima Formation. Oxygen is 
depleted as fluid moves from land-based groundwater sources through permeable rocks to anoxic sediments. Groundwater of the Soquel-Aptos and Salinas Valley regions are known to have low sulfate (undetectable), high manganese and iron (> $100 \mathrm{mM})$, and high silicate $(1900$ to $2000 \mu \mathrm{M}$; Muir, 1982; Ayers et al., 1994). Interstitial fluids trapped in sediments will mix with fresh water as the aquifer-based fluid initially moves to the sediment surface. Fresh water will dominate the chemical signature after initial flow has replaced interstitial fluids. Redox conditions are suboxic due to the low organic matter concentration of fresh water limiting aerobic respiration causing a suboxic, rather than anoxic, environment. Low sulfide concentrations are expected due to the low sulfate concentrations of the source fluid as well as the suboxic, rather than anoxic, environment. The Purisima Formation, deposited in a shallow water marine environment, may contain some residual sea water and associated sulfate that may increase sulfide concentrations at aquifer forced cold seeps (Greene, personal communication).

The concentration of the reduced ions of manganese and iron are expected to relatively high, in comparison to tectonic and hydrocarbon predominated sites, because high manganese and iron concentrations of aquifer-based water supplements the oxides available in sediments. Actual concentrations of $\mathrm{Mn}^{2+}$ and $\mathrm{Fe}^{2+}$ are controlled by manganese and iron carbonate solubility (Pedersen and Price, 1982). Insoluble sulfide precipitates are minimal, if present at all. Silicate concentrations are similarly expected to be high in comparison to hydrocarbon and tectonic predominated sites because interstitial silicate are supplemented by the high concentration of silicate in aquifer-based fluids is that rely solely on the generation of silicate from biogenic opal dissolution. Detectable methane, if present, is expected to be totally biogenic. 


\section{SUMMARY}

The predictions of the chemical composition of cold seep fluids produced by each type of source/expulsion/migration mechanism are summarized in Table 3. A range of concentrations for the analytes sulfide, reduced iron, and reduced manganese cannot be estimated due to the complexity of the diagenic processes in sediments and many unknown factors. Silicate concentrations are expected to range from a total of 200 to $600 \mu \mathrm{M}$ at tectonic compression and hydrocarbon generation sites. Aquifer driven sites are expected to have total silicate concentrations of $>600 \mu \mathrm{M}$ and possibly as high as $2,000 \mu \mathrm{M}$. The relative concentrations are based upon the expected diagenic processes that will predominate the expulsion method and the assumption that sediments, within the Monterey Bay region, are similar in composition. Four cold seeps sites were studied to determine if the relative concentration of $\mathrm{S}^{2-}, \mathrm{Fe}^{2+}, \mathrm{Mn}^{2+}$, and $\mathrm{Si}$ present and if additional evidence supports the assignment of a specified source/expulsion/migration mechanism. This will be the focus of the remainder of this thesis.

Table 3. Fluid expulsion methods and expected relative ion concentration for sulfide, reduced iron, reduced manganese, and silicate.

\begin{tabular}{|c|c|c|c|c|}
\hline $\begin{array}{r}\text { Expulsion } \\
\text { Method }\end{array}$ & $s^{2-}$ & $\mathrm{Fe}^{2+}$ & $\mathrm{Mn}^{2+}$ & $\mathrm{Si}$ \\
\hline $\begin{array}{c}\text { Tectonic } \\
\text { Compression }\end{array}$ & Intermediate & Lowest & Intermediate & $\begin{array}{c}\text { Lowest - } \\
\text { Intermediate }\end{array}$ \\
\hline $\begin{array}{l}\text { Hydrocarbon } \\
\text { Generation }\end{array}$ & Highest & Lowest & $\begin{array}{c}\text { Lowest - } \\
\text { Intermediate }\end{array}$ & Intermediate \\
\hline $\begin{array}{l}\text { Aquifer } \\
\text { Forcing }\end{array}$ & Lowest & Highest & Highest & $\begin{array}{l}\text { Highest - } \\
\text { Intermediate }\end{array}$ \\
\hline
\end{tabular}




\section{METHODS}

\section{FIA PRINCIPLES}

Samples were collected and analyzed in situ by continuous flow spectrophotometric determination based on Flow Injection Analysis (FIA) principles. FIA was developed to automate analysis of fluid samples in a serial approach (Ruzicka and Hansen, 1988). A liquid sample is pumped into a continuously flowing carrier fluid moving through a small diameter tube. Reagents are added and mixed, and reactions occur within the tubing. Long segments of tubing, known as reactors, allow for mixing of reagents and sample as well as increased transit time to provide an adequate interval for the chemical reaction to develop. The reaction product is transported to flow-through cells with detectors, which measure and record the absorbance of the product. Blanks and standards of known concentration are analyzed at regular intervals to compare to sample signal and determination of concentration.

FIA was developed from automated chemical analysis instruments, which essentially performed manual operations in a conveyor belt configuration

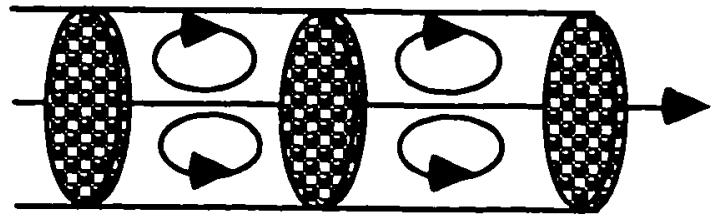

Figure 11. FIA system of sampling. A bicircular motion of a sample plug bounded by bubbles ensures sample separation and complete mixing.
(Ruzicka and Hansen, 1988). FIA modifies the concept of discrete sample analysis by injecting the liquid sample into a continuously flowing carrier fluid separated by bubbles. Homogenous mixing of analyte and reagents occurs within the sample plug from an opposing bicircular circulation pattern (Figure 11) caused by friction associated with the tube wall. 
Fluids moving though a conduit experience drag where the fluid meets the wall. This drag results in the fluid moving faster in the center of the tubing, which reduces mixing and elongating the sample plug area. Smearing of the sample becomes a problem in long segments of tubing as samples are elongated by wall drag (Ruzicka and Hansen, 1988). Ruzicka and Hansen (1988) show that "(a) the reagent becomes more readily mixed with the sample, and (b) the axial dispersion of the sample zone is reduced" by increasing turbulence when a sudden change in flow direction is caused. Thus, reduction of sample smearing and increased reagent mixing can be accomplished by inducing bending in reaction tubing so that the fluid must change directions abruptly and often. "Knitting" reactor tubing forces a directional change every few centimeters, which increases mixing and reduces sample smear.

In addition, FIA modifies the concept that a chemical steady state must be reached to determine concentrations of the analyte (Ruzicka and Hansen, 1988). Instead, it is essential that each sample experience exactly the same treatment. Calibration of the instrument is accomplished by repeated analysis of known standards and blanks (Ruzicka and Hansen, 1988; Johnson, Beehler, and Sakamoto-Arnold, 1986).

Spectrophotometric chemical reactions lend themselves to FIA analysis, as demonstrated by the determination of sulfide (Figure 12). Methylene blue, a thiazine dye, is developed when N,N-dimethyl-p-phenylene diamine dihydrochloride (amine) and ferric chloride $\left(\mathrm{FeCl}_{3}\right)$ react with a slightly acidified sample containing sulfide (Cline, 1969). In the FIA system described by Sakamoto-Arnold, Johnson, and Beehler (1986), sample and amine are drawn by a pump and mixed in approximately $50 \mathrm{~cm}$ of $0.8 \mathrm{~mm}$ i.d. Teflon tubing. Ferric chloride is injected via a rotary injection valve at 1.5 minute 
intervals into the carrier nuid of $0.6 \mathrm{~N}$ hydrochloric acid $(\mathrm{HCl})$. The carrier fluid merges with the sample/amine mixture to combine and react in $100 \mathrm{~cm}$ of $0.8 \mathrm{~mm}$ i.d. reactor tubing. Where $\mathrm{FeCl}_{3}$ is present, methylene blue is developed. This dye is measured by passing it through photometric detector consisting of an LED light source, $660 \mathrm{~nm}$ interference filter and a broadband photodiode. The percent (\%) transmittance is measured and recorded by a microcomputer.

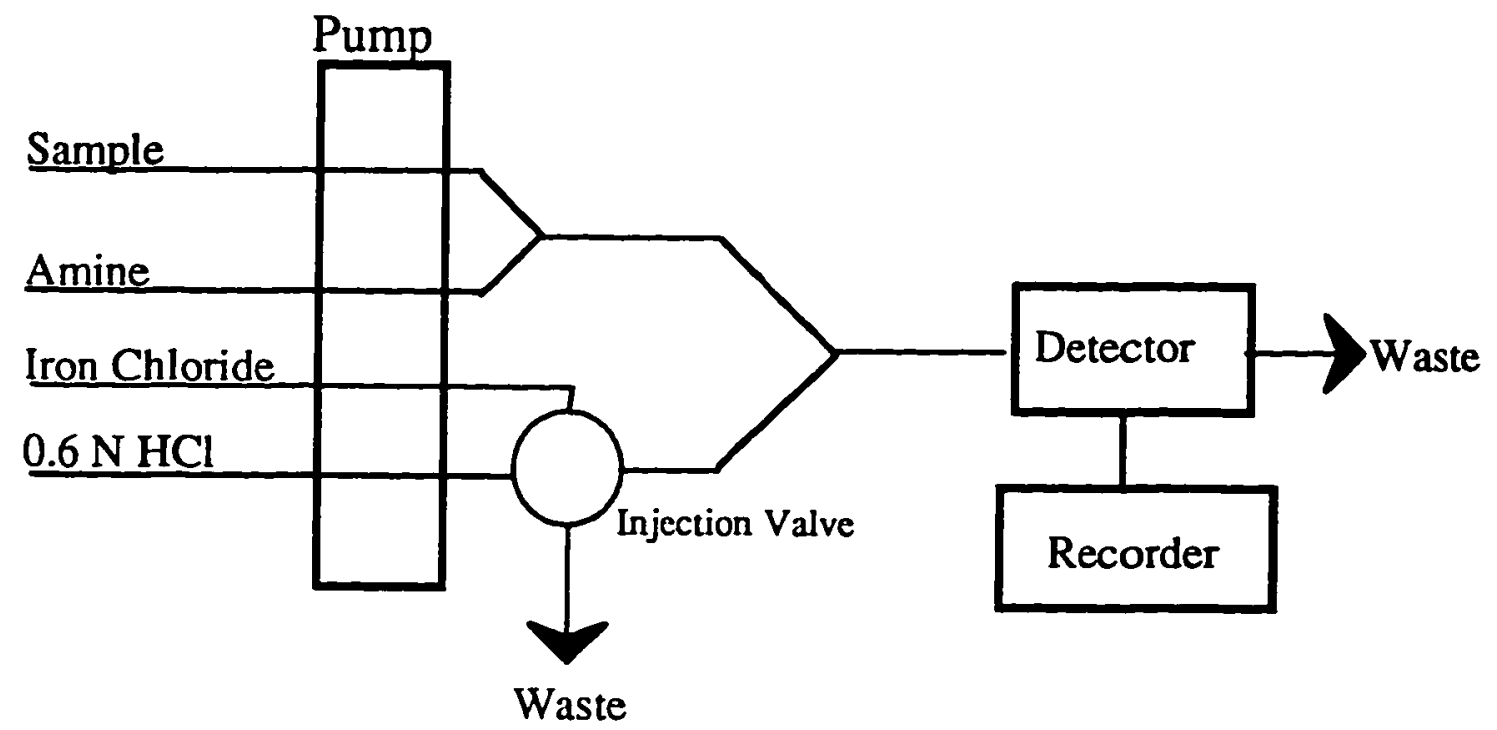

Figure 12. FIA analysis of sulfide as described by Sakamoto-Amold, Johnson, and Beehler (1986). The injection of reagents into the sample stream increases sensitivity.

\section{INSTRUMENTATION}

In situ continuous flow colorimetric chemical analysis was used to determine sulfide, manganese, silica, and total iron concentrations of cold seep fluids. Samples were collected by drawing interstitial fluid, 3 to 10 centimeters 
below the sediment surface, through a 10 micron solvent filter (Rainin part number A-427) into tubing that delivered the sample to the submersible chemical analyzer.

Two instruments were used in this work. Both analyzers, based on modified FIA principles, (Grasshoff and Chan, 1971; Johnson, Beehler, and SakamotoAmold, 1986; Massoth et al., 1991; Sakamoto-Amold, Johnson, and Beehler, 1986; Thomsen, Johnson, and Petty, 1983), utilize a peristaltic pump to transfer sample and reagents to LED photodiode detectors. Sample and reagents are mixed in $0.5 \mathrm{~mm}$ i.d. Teflon tubing of varying length, where the reaction produces color. The concentration of the dye is detected by the photometer of specific wavelength selected for maximum absorption in the range of color developed (Johnson, Beehler, and Sakamoto-Arnold, 1986). Standards are introduced automatically or by command by switching valves. An electronics module, contained in a water tight pressure housing, controls the pump and valves, provides communication protocols for real time analysis and control, and logs data.

\section{SCANNER}

The initial instrument utilized was a two channel (sulfide and silicate) submersible chemical analyzer (SCANNER; Johnson, Beehler, and SakamotoAmold, 1986; Thomsen, Johnson, and Petty, 1983). The SCANNER utilizes a 24 volt D.C. gear motor (TRW EM-15 with 180:1 reduction gear) with internal optical tachometer to drive an 8-channel peristaltic pump (Rainin 39-613). Standard color coded double stop peristaltic pump tubing was used. Three Lee Company 12 volt solenoid pinch valves, with screw on or sleeve fittings, regulated the switching between sea water (sample), high, and low standard. 
Pressure compensated housings for the valves and gear motor were filled with Carnation industrial vegetable oil. The gear motor spring pressure for the brushes was approximately doubled to ensure proper performance while immersed in oil. The peristaltic pump-head was unhoused and exposed to ambient pressure.

The electronics unit, described by Johnson, Beehler, and Sakamoto-Arnold (1986), was housed in an aluminum cylinder $(63 \mathrm{~cm}$ long with $2.54 \mathrm{~cm}$ wall and $15.2 \mathrm{~cm}$ i.d.) with double O-ring seals on end caps at either end. Four 12 wire penetrators (SeaCon) provided electrical and data connections between the electronics unit, pump, valves, detectors, the ROV, and the laptop computer used to monitor and control the chemical analyzers. The Monterey Bay Aquarium Research Institute (MBARI) ROV Ventana supplied a 24 volt power source for the gear motor and valve actuation. A Duracell 15 volt, 20 amp hour, alkaline battery pack (Energy Sales) provided a second power source for digital logic and analog signals. The battery pack, housed in the aluminum cylinder with the electronics unit, provided isolation from voltage spikes and power interruptions for sensitive computer components.

The central processing unit, a Hitachi HD6303R, controlled communication, data collection and storage, and valves. The microprocessor used a Hitachi HD146818 real-time clock to time events and record starting and ending times for the SCANNER data record. Memory, mechanical control, and analog signals are described by Johnson, Beehler, and Sakamoto-Amold, (1986) and were unchanged. Data were collected and stored within the SCANNER electronics module. Additionally, communication via an RS-232 line allowed the information to be transferred to and from a laptop executing specially designed software to monitor and control the SCANNER. 
Detectors were composed of a flow through cell with a LED phototransistor photometer encased in a pressure-compensated, oil-filled container. The SCANNER utilized Siemens LPT-100 broadband phototransistors in all detectors Sulfide was analyzed using a Hewlett-Packard HEMT-3300 near-infrared LED with a maximum emission of $675 \mathrm{~nm}$. A Radio Shack 276-143 infrared LED with a maximum emission of $880 \mathrm{~nm}$ was used to determine of silicate.

The SCANNER introduces sample fluid as a continuous stream rather than injecting sample fluid into a carrier. Eliminating the injection valve reduces the complexity of the instrument and the possibility of mechanical failure under extreme in situ conditions, notably cold and increased pressure at depth. Reagents are added at appropriate intervals along the reaction manifold by flanged T-fitting connectors and mixed in knitted reactors $(0.5 \mathrm{~mm}$ i.d.) of appropriate lengths.

\section{SUAVE}

The second, and primary, analyzer used in this study was the SUAVE (Submersible system Used to Assess Vented Emissions). The SUAVE unit was patterned after the SCANNER (Johnson, Beehler, and Sakamoto-Amold, 1986) with upgrades to the initial design and inclusion of additional sensors as described by Massoth et al., (1991) and Massoth (1991, 1991a). A important change was the upgrade from a 2 channel chemical analyzer to a 6 channel system. The SUAVE components were changed to allow for reduction in size and weight.

The peristaltic pump was upgraded to a 12 channel device driven by a 24 volt Pittman DC motor. The motor ran within an air filled titanium alloy pressure housing designed to withstand 7500 psi. Ismatec Mini-Pulse flexible 
tube holders applied independent and uniform pressure to three-stop autoanalysis tubing (Ismatec) used for reagents and sample on the 8 roller pumphead. Color coded Ismatec three-stop peristaltic pump tubing was used to provide easy determination of pump rates. A circuit board mounted to the motor provided valve and motor control and information about pump performance (RPM); as well as voltage and current draw of the SUAVE electronics. A YSI 46008 glass encased thermistor registered temperature independently from the CTD.

Three Lee Co. 3-way solenoid valves, similar to those found in SCANNER, allowed switching between standards and sample (sea water or interstitial fluids). A clear acrylic housing, that encases the valves, was filled with Carnation oil (dielectric) and pressure compensated by a diaphragm.

The SUAVE electronics package consisted of 3 custom printed circuit boards. which controlled detectors, thermistors, and transmissometer encased in an aluminum pressure housing . LED current, offset, and gain were controlled by means of a software/firmware interface to the detector circuitry. Procedures for the analog, motor/valve, data storage boards, and CTD sensors were directed by two $68 \mathrm{HCll}$ microprocessors, which used FORTH and assembly language programs. A $7.34 \mathrm{MHz}$ CPU clock utilized a $32 \mathrm{kHz}$ oscillator to provide real-time reference for recorded samples. Eighteen pie-shaped Brantner connectors provided communication between the electronic units of SUAVE, the ROV, and the experimenter.

An alkaline battery pack, within the electronics pressure housing, provided independent power for SUAVE electronics. A 24 volt external power source provided by the ROV powered the peristaltic pump, valve switching, and other instruments. 
SUAVE detectors were constructed of a 2 or $4 \mathrm{~cm}$ pathlength Helma quartz flowcell with a $1.5 \mathrm{~mm}$ diameter path, and an LED, and a photodiode element within a PVC housing. The PVC housing were filled with oil to compensate for pressure.

\section{CHEMICAL ANALYSIS}

\section{Sulfide Analysis}

Sulfide determination was performed by the methylene blue method (Cline, 1969; Fonselius, 1983; Greenberg, Clesceri, and Eaton, 1992) modified for continuous flow analysis (Sakamoto-Arnold, Johnson. Beehler, 1986). All reagents were made up with distilled and deionized water (MQ, Millipore Milli-Q water system) and reagent grade salts.

The amine solution was composed of 0.96 grams of N.N-dimethyl-pphenylene diamine dihydrochloride dissolved in $50 \mathrm{~mL}$ of $6 \mathrm{M}$ hydrochloric acid $(\mathrm{HCl})$. After the amine was dissolved, the solution was diluted to half a liter by adding $450 \mathrm{~mL}$ of MQ using a graduated cylinder. The amine solution was stored in an amber LPE bottle to prevent degradation of the solution from light.

The ferric chloride reagent was made by dissolving 1.4 grams of ferric chloride $\left(\mathrm{FeCl}_{3}\right)$ in $50 \mathrm{~mL} 6 \mathrm{M} \mathrm{HCl}$. The solution was diluted to $50 \mathrm{~mL}$ with $\mathrm{MQ}$. The $\mathrm{FeCl}_{3}$ reagent was light sensitive and was kept in an amber LPE bottle.

Standards were made up just prior to deployment of the SCANNER or SUAVE using a stock sulfide solution as described later. The stock sulfide solution was composed 1 gram EDTA diluted to $500 \mathrm{~mL}$ with $\mathrm{MQ}$ and deoxygenated by bubbling nitrogen gas through it for approximately 1 hour. Sodium sulfide $\left(\mathrm{Na}_{2} \mathrm{~S} \cdot 9 \mathrm{H}_{2} \mathrm{O}\right)$ was prepared by rinsing with $\mathrm{MQ}$ and drying with a clean 
absorbent material to remove sodium sulfite. Twelve grams of the rinsed and dried sodium sulfide were dissolved in the deoxygenated water, giving a 100 $\mathrm{mM} \mathrm{H} \mathrm{H}_{2} \mathrm{~S}$ solution (Sakamoto-Arnold, Johnson, and Beehler, 1986).

The SCANNER utilized a $50 \mathrm{~cm}$ knitted reactor after the introduction of the amine reagent and a $100 \mathrm{~cm}$ reactor after $\mathrm{FeCl}_{3}$ was added. The sample was pumped at approximately $1.42 \mathrm{~mL} / \mathrm{min}$ (yellow/yellow) and both reagents were introduced at a rate of $0.76 \mathrm{~mL} / \mathrm{min}$ (blue/blue). The SCANNER detector for sulfide utilized a near-infrared LED with a maximum wave length of 675 nm (Johnson, Beehler, and Sakamoto-Arnold, 1986).

The SUAVE manifold for sulfide (Figure 13) pumped sample at $0.83 \mathrm{~mL} / \mathrm{min}$ (white/white) to a screw-in T-connector, where the amine reagent was introduced at approximately $0.33 \mathrm{~mL} / \mathrm{min}$ (orange/white) and mixed the solution in a $100 \mathrm{~cm}$ knitted reactor. The $\mathrm{FeCl}_{3}$ was added at $0.33 \mathrm{~mL} / \mathrm{min}$ (orange/white) before it was mixed in $125 \mathrm{~cm}$ of knitted reactor. The final reactant was moved to 2 detectors, linked serially, utilizing a maximum wavelength of $675 \mathrm{~nm}$ with a pathlength of $2 \mathrm{~cm}$.

Iron Analysis

Total iron was determined using N,N-Dimethyl-p-phenylenediamine (DPD) manufactured by Aldrich with ammonia acetate (Hirayama and Unohara, 1988). The 2 molar acetate buffer of $\mathrm{pH} 5.6$ was made by mixing 154.16 grams $\mathrm{NH}_{4} \mathrm{C}_{2} \mathrm{H}_{3} \mathrm{O}_{2}$ in 1 liter $\mathrm{MQ}$. Just prior to deployment, a working solution was made by mixing $10 \mathrm{~mL} 1.2 \%$ hydrogen peroxide $\left(\mathrm{H}_{2} \mathrm{O}_{2}\right)$ and $500 \mu \mathrm{L}$ Brij-35 with $250 \mathrm{~mL}$ of the acetate buffer.

The DPD reagent was made just prior to deployment by mixing 0.5 gram $\mathrm{N}, \mathrm{N}$-Dimethyl-p-phenylenediamine in $200 \mathrm{~mL} \mathrm{MQ}$. One $\mathrm{mL}$ of clean $6 \mathrm{~N} \mathrm{HCl}$ was added. The solution was diluted with $\mathrm{MQ}$ to a final volume of $250 \mathrm{~mL}$. 


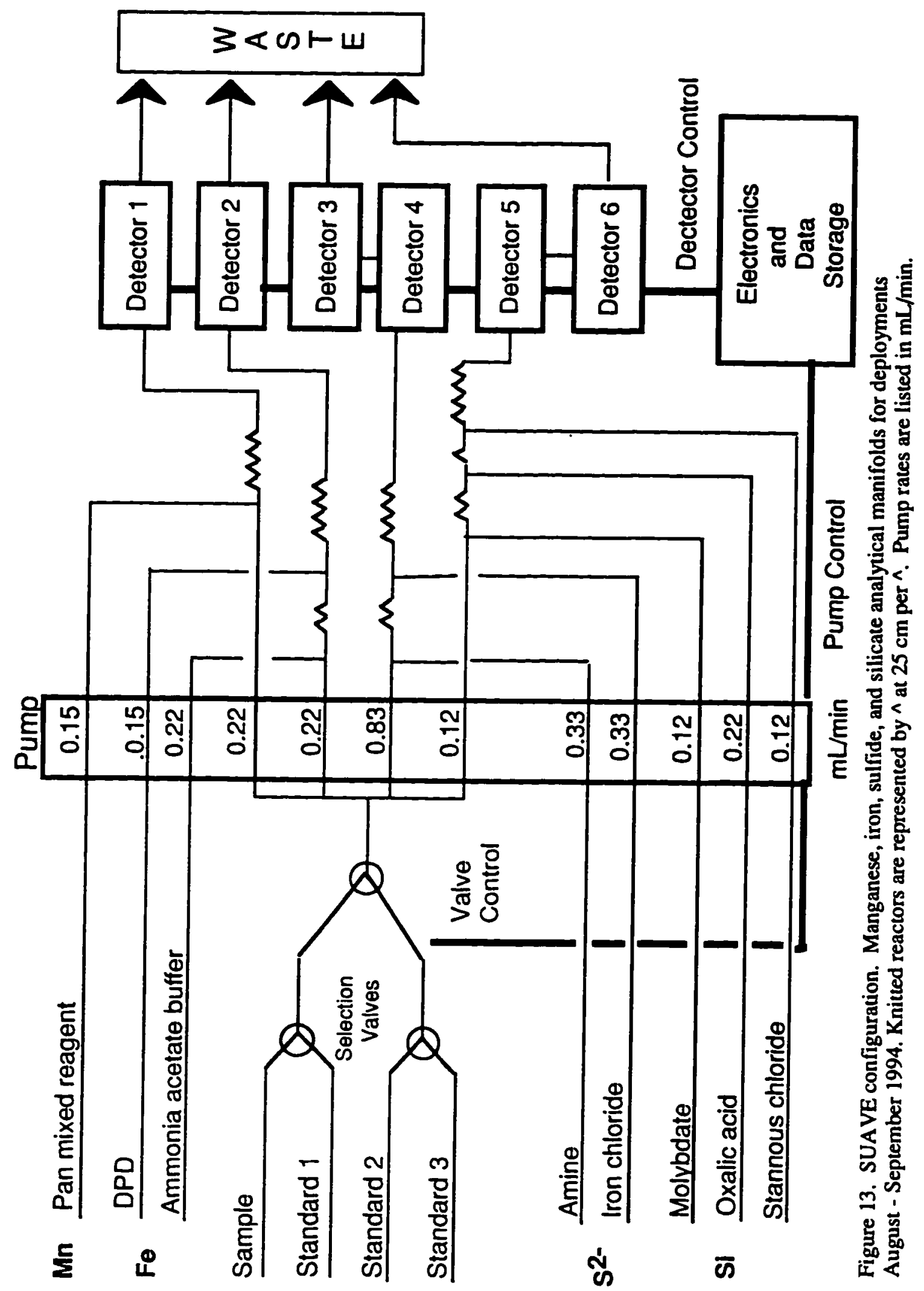


Iron analysis was conducted only when the SUAVE unit was in use. The chemical manifold configuration (Figure 13) pumped a steady stream of sample at approximately $0.22 \mathrm{~mL} / \mathrm{min}$ (orange/yellow) into a 0.5 i.d. Teflon tube. The acetate buffer was introduced at a T-connection at approximately $0.22 \mathrm{~mL} / \mathrm{min}$ (orange/yellow). The sample and acetate buffer were mixed and allowed to react in a $50 \mathrm{~cm}$ knitted reactor of 0.5 i.d. Teflon tubing. DPD was added at a T-connector at approximately $0.15 \mathrm{~mL} / \mathrm{min}$ (green/yellow) and allowed to $\mathrm{mix}$ in a $100 \mathrm{~cm}$ knitted reactor. The final reactant was moved into a detector with a $2 \mathrm{~cm}$ pathlength and maximum wavelength of $569 \mathrm{~nm}$.

The $100 \mathrm{mM}$ stock iron standard was produced by adding 0.1205 grams of analytical grade $\mathrm{FeNH}_{4}\left(\mathrm{SO}_{4}\right)_{2} \cdot 12 \mathrm{H}_{2} \mathrm{O}$ in $250 \mathrm{~mL} \mathrm{MQ}$. The stock solution was stored in an amber LPE boule to protect the solution from light.

\section{Manganese Analysis}

The use of 1-(2-Pyridylazo)-2-naphthol (PAN) as an extractant for transitional metals has been known since the 1950s (Betteridge, Femando, and Freiser, 1963). The PAN method, optimized for the SCANNER and described in detail by Chin (1991), was utilized to determine manganese concentrations. Iron III, found to be an interferant to the manganese determination (Chin, 1991), was mitigated by the use of an Fe(III)-specific chelating agent.

The PAN reagent was made by mixing $45 \mathrm{~mL}$ EtOH in a $250 \mathrm{~mL}$ volumetric flask with 5.0 to $7.5 \mathrm{~mL}$ of Triton X-100 surfactant. 0.05 gram PAN was added to the ethanol mixture and shaken vigorously. A borate buffer, with a pH of approximately 10.87 , was prepared by adding 6.18 grams of $\mathrm{H}_{3} \mathrm{BO}_{3}$ to 1 Liter of MQ water with 4.0 grams of reagent grade $\mathrm{NaOH}$ (Chin, 1991). One hundred $\mathrm{mL}$ of the borate buffer was added to the PAN solution and mixed well by shaking. The Fe(III)-specific chelating agent was made up by adding $3.05 \mathrm{~mL} \mathrm{MQ}$ to a 
vial of $500 \mathrm{mg}$ pharmaceutical grade desferrioxamine B (Desferal ${ }^{\circledR}$, Sigma). Four hundred $\mu \mathrm{L}$ Desferal ${ }^{\oplus}$ solution was introduced and the volume was brought up to $250 \mathrm{~mL}$ with MQ water. The PAN reagent was fully dissolved through vigorous shaking. The surfactant Triton $X-100$ increased the solubility of PAN, making it an effective reagent for determining manganese in natural waters (Chin, 1991; Chin et al., 1994).

The stock manganese standard solution was made from a J. T. Baker Dilut-it Analytical concentration of 1 gram $\mathrm{Mn}^{2+}$. One Dilut-it cartridge was diluted to $100 \mathrm{~mL}$ using MQ to produce a 182 mmolar solution and was stored in a clear LPE bottle.

Manganese was only used with SUAVE deployments and the chemical manifold used for manganese analysis (Figure 13) pumped a steady stream of sample at approximately $0.22 \mathrm{~mL} / \mathrm{min}$ (orange/yellow) into a 0.5 i.d. Teflon tube. The PAN reagent was introduced at a $\mathrm{T}$-connection at approximately 0.15 $\mathrm{mL} / \mathrm{min}$ (green/yellow) and allowed to $\mathrm{mix}$ in a $100 \mathrm{~cm}$ knitted reactor. The product was moved into a detector with a $2 \mathrm{~cm}$ pathlength utilizing a maximum wavelength of $569 \mathrm{~nm}$.

\section{Silicate Analysis}

The molybdenum blue method (Truesdale and Smith, 1976, 1975), modified for continuous flow analysis (Johnson, Beehler, and Sakamoto-Amold, 1986; Thomsen, Johnson, and Petty, 1983) was used to determine dissolved silicate concentrations.

The molybdate reagent was made of 30 grams of ammonium molybdate $\left(\left(\mathrm{NH}_{4}\right)_{6} \mathrm{MO}_{7} \mathrm{O}_{24} \cdot 4 \mathrm{H}_{2} \mathrm{O}\right)$ dissolved in approximately $400 \mathrm{~mL} \mathrm{MQ}$ in a $1 \mathrm{~L} \mathrm{LPE}$ volumetric flask. Seventeen $\mathrm{mL}$ of concentrated sulfuric acid $\left(\mathrm{H}_{2} \mathrm{SO}_{4}\right)$ were 
added and mixed by swirling. The mixture was brought to $1 \mathrm{~L}$ using MQ water, mixed, and stored in an amber LPE bottle.

A stock oxalic acid solution was made up of 70 grams of reagent grade oxalic acid added to approximately $900 \mathrm{~mL}$ of $\mathrm{MQ}$ in a 1 liter volumetric. Twenty $\mathrm{mL}$ concentrated sulfuric acid was added and mixed. The solution was brought to 1 liter by the addition of MQ. The working solution was 1 par stock oxalic acid solution and 1 part $\mathrm{MQ}$. A stock stannous chloride $\left(\mathrm{SnCl}_{2}\right)$ solution was made of 5.5 grams of $\mathrm{SnCl}_{2}$ in $100 \mathrm{~mL} 6 \mathrm{~N} \mathrm{HCl}$. The working reagent was $3.3 \mathrm{~mL}$ of the stock $\mathrm{SnCl}_{2}$ solution to $500 \mathrm{~mL} \mathrm{MQ}$.

Standards were made up just prior to deployment of the submersible analyzer using a stock silicate solution as described later. The $100 \mathrm{mM}$ stock silicate solution was made using 165.90 gram MQ with 1 J. T. Baker Dilut-it silicate cartridge. The stock solution was kept in a $200 \mathrm{~mL}$ clear LPE bottle.

The silicate configuration (Figure 13) pumped sample at approximately 0.12 $\mathrm{mL} / \mathrm{min}$ (orange/green) and merged sample with the molybdate reagent introduced at the same rate into a $50 \mathrm{~cm}$ knitted reactor. The oxalic acid reagent was added at $0.22 \mathrm{~mL} / \mathrm{min}$ (orange/yellow). A $25 \mathrm{~cm}$ knitted reactor was used to mix in the oxalic acid. The final reagent, stannous chloride, was added at $0.12 \mathrm{~mL} / \mathrm{min}$ (orange/green) and mixed in a $100 \mathrm{~cm}$ knitted reactor. The product was measured by a single $2 \mathrm{~cm}$ detector of $880 \mathrm{~nm}$ in the SCANNER and by 2 detectors $(2$ and $4 \mathrm{~cm}$ ) of $880 \mathrm{~nm}$ in the SUAVE unit.

\section{Working Standards}

Standards were made immediately prior to leaving the dock and are shown in Tables 4 and 5. The SCANNER utilized only two chemistries. requiring only sulfide and silicate standards. The SUAVE unit utilized 3 mixed standards of low, medium, and high concentration of sulfide, silicate, iron, and manganese. 
Only high and low concentrations were used for sulfide standards and a single standard was used for iron. This was because iron is known to interfere with the sulfide chemistry.

Approximately 1.5 liters of low iron filtered sea water was deoxygenated by bubbling nitrogen gas through it for 0.5 to 0.75 hour. Two $500 \mathrm{~mL}$ and 1 to 250 $\mathrm{mL}$ LPE volumetric bottles were filled with the deoxygenated sea water. Two hundred $\mu \mathrm{L}$ and $100 \mu \mathrm{L}$ clean aliquots of $6 \mathrm{~N} \mathrm{HCl}$ were added to the $500 \mathrm{~mL}$ and $250 \mathrm{~mL}$ volumetrics, respectively. The sulfide, silicate, iron, and manganese were added from the stock standard solutions to yield the concentrations shown in Tables 4 and 5 . Standards were transferred to modified Playtex baby bottles, care being taken to exclude air during transfer. Standard bottles were transferred to the frame of the SCANNER or SUAVE for deployment.

Table 4. Standards as prepared for SCANNER chemistry.

\begin{tabular}{|c|c|c|}
\hline Analyte & Low Standard & High Standard \\
\hline $\begin{array}{l}\mathrm{S}^{2-} \\
\mathrm{Si}\end{array}$ & $\begin{array}{c}50 \mu \mathrm{M} \\
100 \mu \mathrm{M}\end{array}$ & $\begin{array}{l}100 \mu \mathrm{M} \\
200 \mu \mathrm{M}\end{array}$ \\
\hline
\end{tabular}

Table 5. Standards as prepared for SUAVE chemistry.

\begin{tabular}{|c|c|c|c|}
\hline Analyte & Low Standard & Medium Standard & High Standard \\
\hline$s^{2-}$ & $50 \mu \mathrm{M}$ & $100 \mu \mathrm{M}$ & Not Used \\
\hline $\mathrm{Fe}^{3+}$ & Not Used & Not Used & $100 \mu \mathrm{M}$ \\
\hline $\begin{array}{l}\mathrm{Mn}^{2+} \\
\mathrm{Si}\end{array}$ & $\begin{array}{l}50 \mu \mathrm{M} \\
50 \mu \mathrm{M}\end{array}$ & $\begin{array}{l}100 \mu \mathrm{M} \\
100 \mu \mathrm{M}\end{array}$ & $\begin{array}{l}150 \mu \mathrm{M} \\
200 \mu \mathrm{M}\end{array}$ \\
\hline
\end{tabular}




\section{RESEARCH VESSELS}

The Monterey Bay Aquarium Research Institutes (MBARI) ROV. Ventana, and support vessel, the RIV Point Lobos, as described by Robison (1992) and Greene et al. (1993) were utilized to access the study areas (Photographs 1 and 2). The Ventana is a modified Hysub ATP 40-1850 designed and built by International Submarine Engineering, Ltd. with a rated maximum depth of $1850 \mathrm{~m}$. The Kevlar armored tether consists of 5 copper power conductors and 10 optical fiber elements. A 40 hp electro/hydraulic power pack, for motors and activators, supplied hydraulic power. Observations were made through a Sony DXC-3000, three chip color video camera with a Fujinon 5.5 to $60 \mathrm{~mm}$ zoom lens and a low-light Osprey camera with a fixed focus. Four 400 watt sodium scandium and 2 rheostatically controlled 500 watt incandescent lights provided illumination. A $35 \mathrm{~mm}$ Photosea 1000 attached to the main video housing provided still photo capabilities.

A seven function hydraulic arm built by International Submarine Engineering provided the ability to insert the sample intake tube into the desired area to be sampled. The SUAVE unit was mounted at the rear of the ROV in the caboose. The sample intake tube $\operatorname{ran} 440 \mathrm{~cm}$ from SUAVE, through the interior of the ROV, to the tip of the manipulator arm. The SCANNER was mounted forward just behind the real-time conductivity, temperature, oxygen and depth unit (Seabird) and required a length of $130 \mathrm{~cm}$ of intake tubing.

The SUAVE and SCANNER required a 24 volt power supply and an RS-232 connection, routed through the tether. Thus, the support ship supplied power for the peristaltic pump and valve activation. The RS-232 connection ran directly to a laptop computer located in the control room which allowed communication to and from the chemical analyzers. 


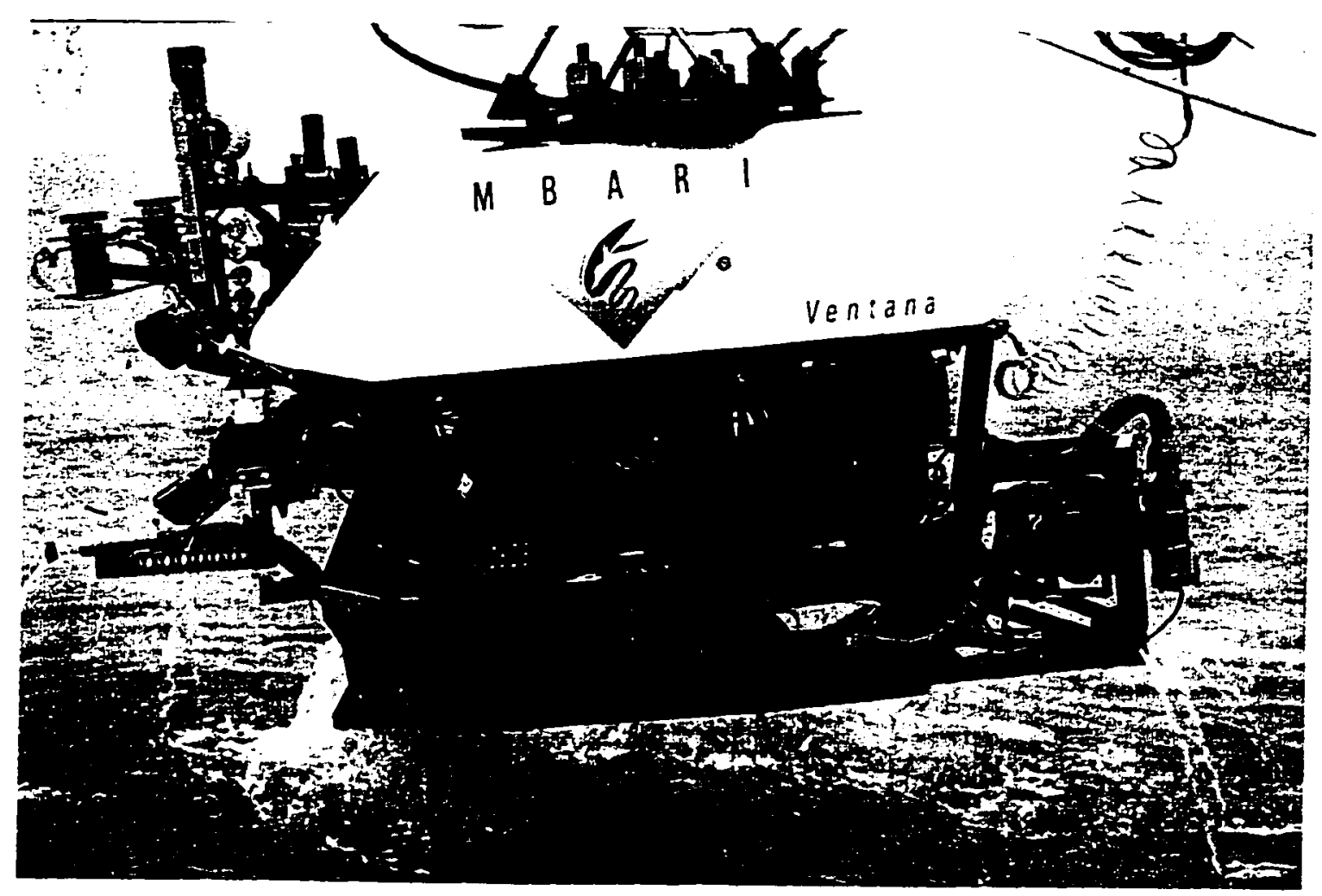

Photograph 1. The MBARI Remotely Operated Vehicle (ROV), Ventana.

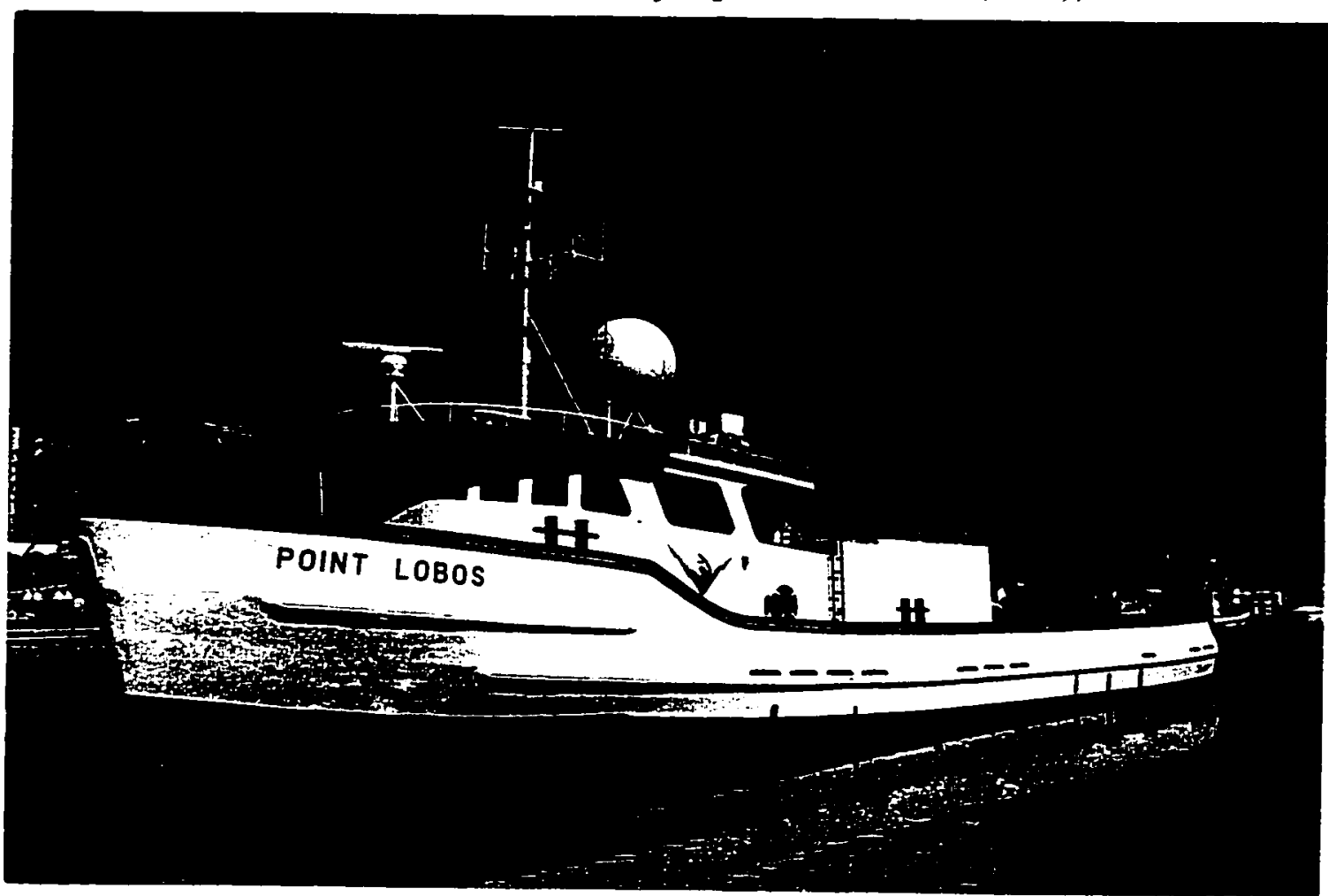

Photograph 2. The Ventana support ship, the research vessel Point Lobos. 


\section{SAMPLING STRATEGY}

\section{BACKGROUND CONCENTRATIONS}

The background concentration of all chemicals in the water column were measured while the sample inlet was above the sediments and ambient sea water was circulating though the in situ analyzer. Background concentrations for sulfide, manganese, and iron were essentially zero and assumed to represent the instrument blank. Silicate concentrations in the water column were calculated by using the average ambient temperature and associated silicate concentrations estimated from historical data published by Martin and Gordon (1988). These values ranged from $80 \mu M$ at the shallow Mount Crushmore site to $140 \mu \mathrm{M}$ at Faulted Wall, the deepest site of the study (Table 6). Silicate concentrations are reported as deviations from background concentrations, therefore ambient sea water concentrations are reported as $\Delta 0$ silicate.

Table 6. Calculated background silicate concentrations by site. Historical data obtained from Martin and Gordon (1988).

\begin{tabular}{cccc}
\hline Site & Temperature & Silicate $\mu \mathbf{M}$ & Depth \\
\hline Clam Field & $4.01-4.41^{\circ} \mathrm{C}$ & $110 \pm 10$ & 890 \\
Mud Volcano & $3.74-3.96^{\circ} \mathrm{C}$ & $120 \pm 10$ & 1000 \\
Mount Crushmore & $4.9-5.69^{\circ} \mathrm{C}$ & $80 \pm 10$ & 620 \\
Faulted Wall & Estimated $3.5^{\circ} \mathrm{C}$ & $140 \pm 10$ & 1390 \\
\hline
\end{tabular}

\section{SAMPLE GATHERING}

Active seep regions were identified by darkened sediments (indicating iron-sulfide precipitates), bacterial mat, and/or live Calyptogena sp. clams. 
Samples from each site were taken at several locations along a transect from outside an active seep region, through the central area of the seep, continuing onto the other side of the active seep zone (Figure 14). Samples were taken by inserting a 10 micron solvent filter directly into the top 3 to $10 \mathrm{~cm}$ of sediments and drawing interstitial fluids in for analysis. The pumping rate for all four chemistries was approximately $1.4 \mathrm{~mL} \cdot \mathrm{min}^{-1}$ for about 5 minutes. This extracted roughly a $7 \mathrm{~mL}$ sample. Fluid flow to replace interstitial fluids, that are taken up by the analyzer, was slower than the sample pumping rate and entrainment of ambient sea water occurred (Figure 15). Entrainment of ambient sea water altered the absolute concentrations of the measured interstitial constituents but not the relative concentration of the ions measured.

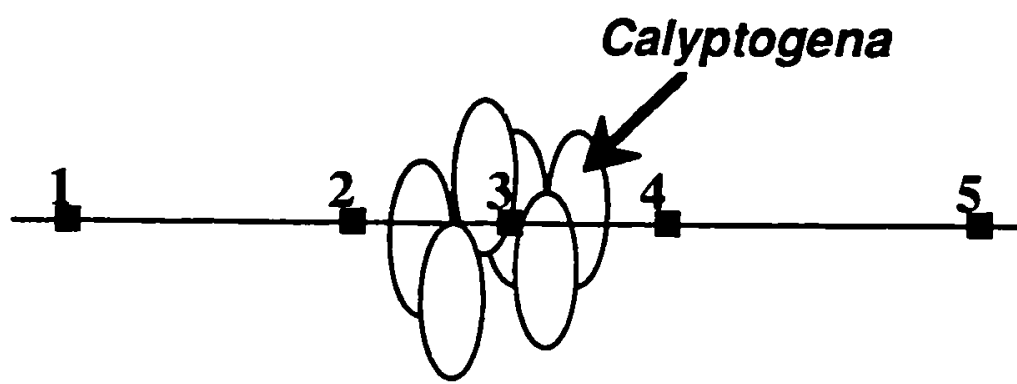

Figure 14. Sample strategy at active seep regions. Control readings at sites 1 and 5 were taken before and after sample readings at the edge (sites 2 and 4) and in the central area (site 3 ) of active seep regions.

Prevailing currents, size of seep areas, and equipment constraints often made it impossible to traverse a straight line through active seep regions. Sites where transects were taken across active seeps showed profound 
increases in reduced ions, especially sulfide, in regions of live clams. Brown sediments within 7 to $10 \mathrm{~cm}$ outside active seeps regions showed concentrations of reduced ions at background levels, which are essentially zero for sulfide, manganese, and iron, and ambient sea water concentrations for silicate.

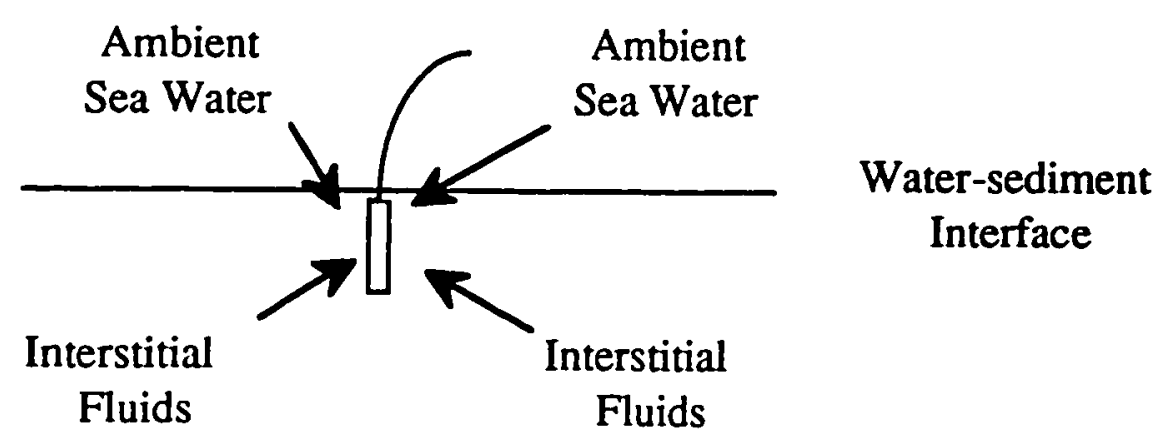

Figure 15. Entrainment of sea water during sampling. Interstitial fluids were pumped into sample tubing at $7 \mathrm{~mL} / \mathrm{min}$, causing a deficit of fluid at the point where the sample intake is inserted into sediment. Ambient sea water was drawn into the sediment mixing with the sample fluid.

The concentrations of each analyte measured on the transects are presented in the Results section as figures of ion concentration versus time. The relative location of each sampling site on the transect through an active seep region were determined by analysis of video tape records and notes taken at the time of the measurements. These locations are marked as station numbers on the figures of concentration versus time for each site described in the Results section.

The environments of hydrothermal systems are variable in time (Johnson et al., 1988). For example, there is evidence of tidal variation in the flow from 
hydrothermal vents (Johnson et al., 1994). However, to my knowledge corresponding tidal processes at cold seeps have not been verified at this time. The possible biases that might be introduced in these results due to temperature variability was, therefore, ignored.

Entrainment of ambient sea water during sampling alters the absolute concentration of the analyte measured. The ratio of ions should remain constant despite sea water entrainment and the results are presented as figures of sulfide, iron, and manganese concentrations versus silicate concentration. These graphs are additionally useful in providing insight into the conservative nature of the analyte within the sediments of active seep regions.

\section{CONSERVATIVE AND NONCONSERVATIVE IONS}

Conservative ions are affected by physical processes (i.e., diffusion, bioturbation, and mixing of unique water masses) and maintain a constant proportion to other conservative ions (i.e., the major ions of sea water which are chloride, sodium, calcium, magnesium, and sulfide) in marine environments. Nonconservative ions do not maintain constant proportions with conservative ions because they are utilized or generated by chemical or biological processes. Concentrations of conservative ions plotted versus other conservative ions will produce a straight line (Figure 16a). Nonconservative ions plotted against conservative ions produces a curve. An ion that is consumed by chemical or biological processes produces a concave downward curve (Figure 16b) while a concave upward curve is produced when the analyte is generated (Figure 16c). 
Silicate, in this study, is considered a conservative ion because it quickly reaches a maximum and constant concentration in sediments and does not participate in redox reactions of anoxic sediment (Figure 4; McManus et al., 1995). Sulfide, iron, and manganese are possibly nonconservative in their nature, because they participate in the redox reactions of anoxic sediments as well as biological processes. Establishing the ratio of measured chemicals provides the ability to "fingerprint" the chemical composition of various seep sites and to determine if diagenesis is altered by initial fluid types and fluid expulsion methods. Additionally, spatial variation of chemical concentrations and ratios can be mapped to establish chemical heterogeneity of a seep region.

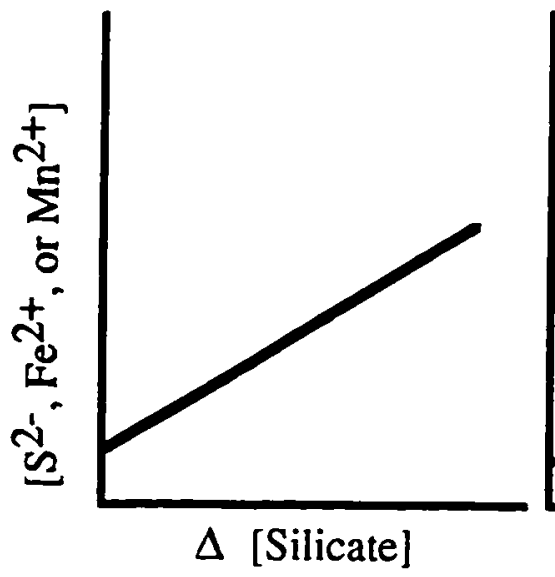

(a)

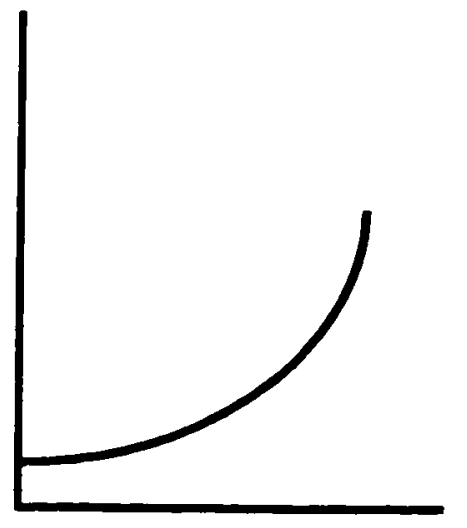

$\Delta$ [Silicate]

(b)

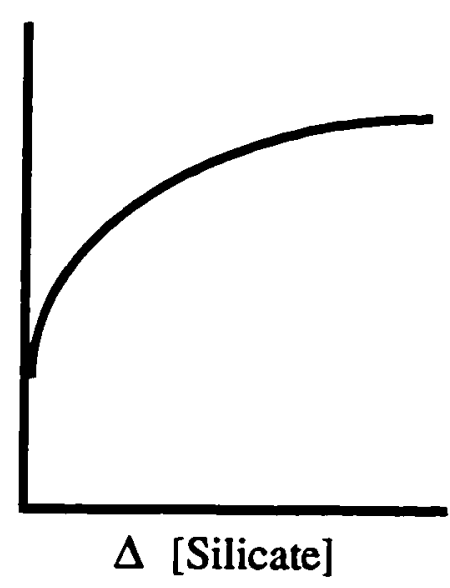

(c)

Figure 16. Idealized graphs of conservative and nonconservative ions. Conservative and nonconservative ions show distinct graphs. A linear gradient (a) reflects a constant ratio between the conservative silicate ion, a concave downward curve (b) indicates the removal of the ion, and a concave upward curve (c) indicates the production of the ion. 


\section{RESULTS}

\section{SITES}

A total of 13 dives were made in Monterey Bay from October of 1993 to October of 1994 to analyze the chemical environment of cold seeps. Four cold seeps sites (Table 7) were identified and studied to determine if a predominant chemical signature could be found. Data from 9 dives are presented in this thesis (Table 8). Data was not collected from the remaining 4 dives due to equipment failure. Sites were studied repeatedly when possible, to provide measurements across visible seep sites as well as in the surrounding region.

Table 7. Site name, latitude, longitude, and approximate depth in meters.

\begin{tabular}{cccc}
\hline Site & Latitude & Longitude & $\begin{array}{c}\text { Depth } \\
\text { (meters) }\end{array}$ \\
\hline Clam Field & $36^{\circ} 44^{\prime} 03^{\prime \prime} \mathrm{N}$ & $122^{\circ} 02^{\prime} 36^{\prime \prime} \mathrm{W}$ & 890 \\
Mud Volcano & $36^{\circ} 44^{\prime} 44^{\prime \prime} \mathrm{N}$ & $122^{\circ} 16^{\prime} 40^{\prime \prime} \mathrm{W}$ & 1000 \\
Mount Crushmore & $36^{\circ} 47^{\prime} 05^{\prime \prime} \mathrm{N}$ & $122^{\circ} 02^{\prime} 36^{\prime \prime} \mathrm{W}$ & 620 \\
Faulted Wall & $36^{\circ} 44^{\prime} 09^{\prime \prime} \mathrm{N}$ & $122^{\circ} 00^{\prime} 38^{\prime \prime} \mathrm{W}$ & 1390 \\
\hline
\end{tabular}

The Monterey Bay region is the location of this study (Figure 17). The Clam Field site resides within the Monterey Canyon as it tums southward towards the city of Monterey. Mount Crushmore is located at the mouth of Soquel Canyon as it approaches the Monterey Canyon. Mud Volcano is positioned west of Monterey Bay and the San Gregorio fault zone on the feature known as the Smooth Ridge. Faulted Wall is located on the east wall of the Monterey Canyon almost directly east of the Clam Ficld site. 
Table 8. Collection site, MBARI dive number, Julian day, date, and instrument.

\begin{tabular}{|c|c|c|c|c|}
\hline Site & Dive Number & JDay & Date & Instrument \\
\hline $\begin{array}{c}\text { Clam Field } \\
\text { Clam Field } \\
\text { Clam Field } \\
\text { Mud Volcano } \\
\text { Mud Volcano } \\
\text { Mud Volcano } \\
\text { Mount Crushmore } \\
\text { Mount Crushmore } \\
\text { Faulted Wall }\end{array}$ & $\begin{array}{c}698 \\
796 \& 797 \\
806 \\
699 \\
800 \\
803 \\
787 \\
790 \\
792\end{array}$ & $\begin{array}{l}010 \\
249 \\
269 \\
011 \\
256 \\
263 \\
224 \\
230 \\
234\end{array}$ & $\begin{array}{c}\text { 10-Jan-94 } \\
6 \text {-Sept }-94 \\
26-\text { Sept-94 } \\
11-J a n-94 \\
13-S e p t-94 \\
20-\text { Sept-94 } \\
12-\text { Aug-94 } \\
18-\text { Aug-94 } \\
\text { 22-Aug-94 }\end{array}$ & $\begin{array}{l}\text { SCANNER } \\
\text { SUAVE } \\
\text { SUAVE } \\
\text { SCANNER } \\
\text { SUAVE } \\
\text { SUAVE } \\
\text { SUAVE } \\
\text { SUAVE } \\
\text { SUAVE }\end{array}$ \\
\hline
\end{tabular}

\section{CLAM FIELD}

The Clam Field location, also known as Clamfield South (Orange et al., submitted b), lies in about 900 meters of water at $36^{\circ} 44^{\prime} 03^{\prime \prime} \mathrm{N}, 122^{\circ} 01^{\prime} 59^{\prime \prime} \mathrm{W}$ (Figure 17). The seep site is located in a long band ( $2 \mathrm{~m} \times 150 \mathrm{~m}$ ) running along an exposed segment of the highly fractured Purisima Formation which unconformably overlies the Monterey Formation (Barry et al., submitted a; Greenc. 1977). Clam Field is located east of the Palo Colorado-San Gregorio fault zone, thus the basement is the granitic Salinian block (Greene and Hicks, 1990). Faults, at this site, appear to capture, direct, and focus expulsed fluid along fracture lines and regions of increased permeability (Greene et al., 1993; McAdoo et al., 1994; Orange et al., submitted a).

The biological community is dominated by the clam $C$. kilmeri with bacterial mat Beggiatoa sp. associated with clam sites (Barry et al., submitted a). The clam site occurs on a 15 to $20^{\circ}$ slope at the base of an approximately 2 meter cliff (Barry et al., submitted a). Sediments are grayish-brown to black in nature and are interspersed among rare carbonate structures. 


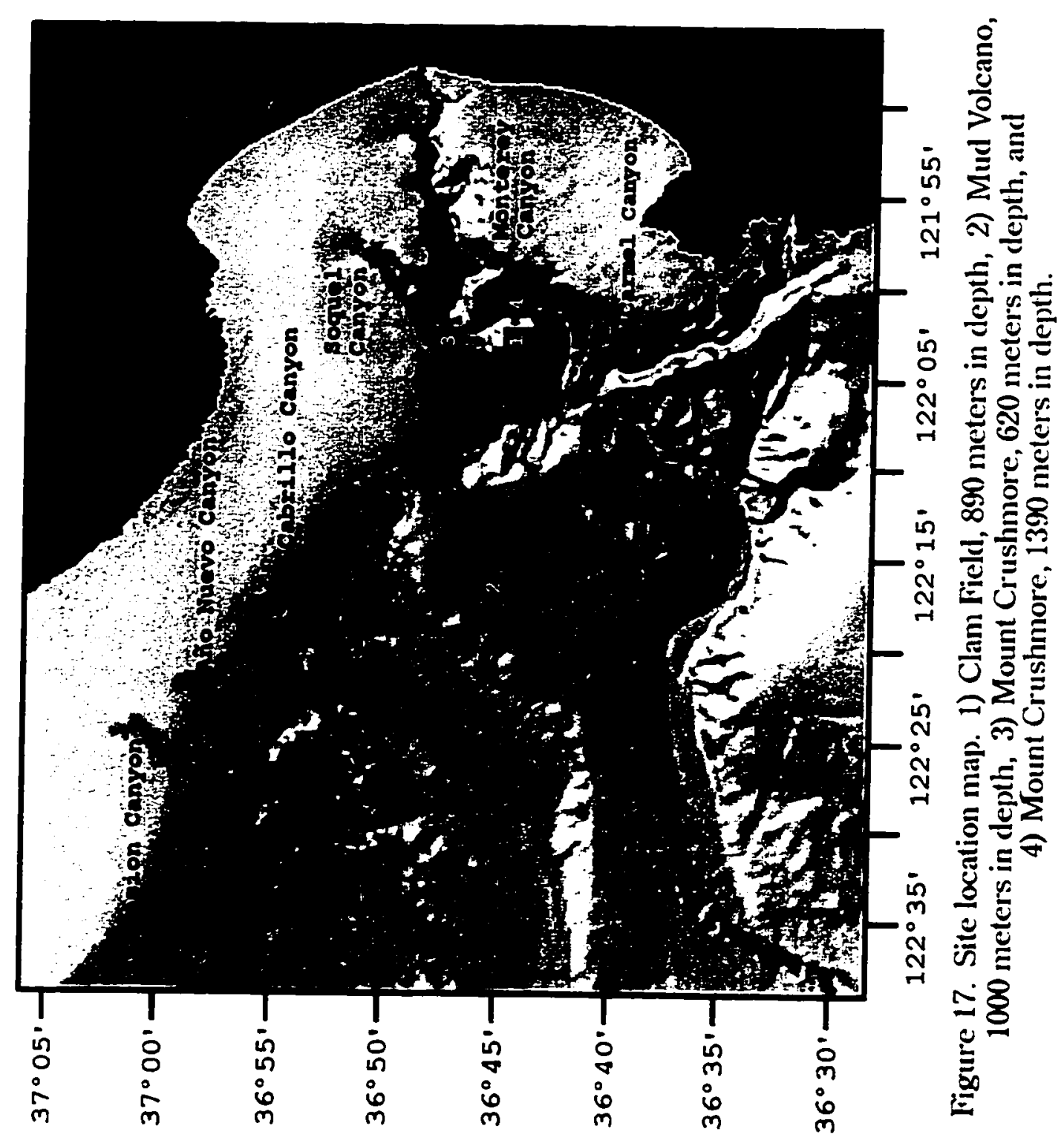




\section{Scanner Data}

Clam Field was investigated three times on January 10, 1994, dive 698; September 6, 1994 consisted of 2 dives 796 and 797 with a surface interval; and dive 806 was conducted on September 26, 1994 (Appendix A-1 to A-3).

Dive 698: The two channel SCANNER was used during dive 698 to measure sulfide and silicate concentrations at 9 stations (Figure 18; Appendix A-1). Station 1, located above clam siphons in the water column, had a slightly elevated concentration of silicate at $27 \mu \mathrm{M}$ and background levels of sulfide. Station 2, located in brown sediment with scattered disarticulated clam shells, had $2 \mu \mathrm{M}$ sulfide and $10 \mu \mathrm{M}$ silicate. Both sites were expected to have background levels of silicate and sulfide because they were above and outside active seep regions, yet had slightly elevated silicate concentrations. Readings taken in the central area of a bacterial mat, station 3, yielded elevated levels of sulfide, $49 \mu \mathrm{M}$, and silicate, $84 \mu \mathrm{M}$. Station 4 , located above live clam siphons in the water column, had marginally elevated sulfide and silicate concentrations measured $6 \mu \mathrm{M}$ and $16 \mu \mathrm{M}$ respectively. At station 5 the probe was moved into the sediment below station 4 and the concentrations of sulfide and silicate increased to $49 \mu \mathrm{M}$ and $115 \mu \mathrm{M}$.

Regions of active seep sites, where the intake filter penetrated sediment, stations 6 to $7 \mathrm{a}$, show sulfide values averaging $51 \pm 0.3 \mu \mathrm{M}(\mathrm{n}=4$, ), silicate values averaging $108 \pm 1.3 \mu \mathrm{M}(\mathrm{n}=4)$ ranging from 104 to $113 \mu \mathrm{M}$ above ambient sea water concentrations. Station 8 , approximately $10 \mathrm{~cm}$ outside of an area of densely packed clams, measured sulfide at $23 \mu \mathrm{M}$, and silicate at $6 \mu \mathrm{M}$. Station 9 was an area of widely dispersed live clams with clam trails evident in dark brown sediment. In the region of station 9, sulfide levels of $2 \mu M$ and silicate concentrations consistent with ambient sea water were measured. 

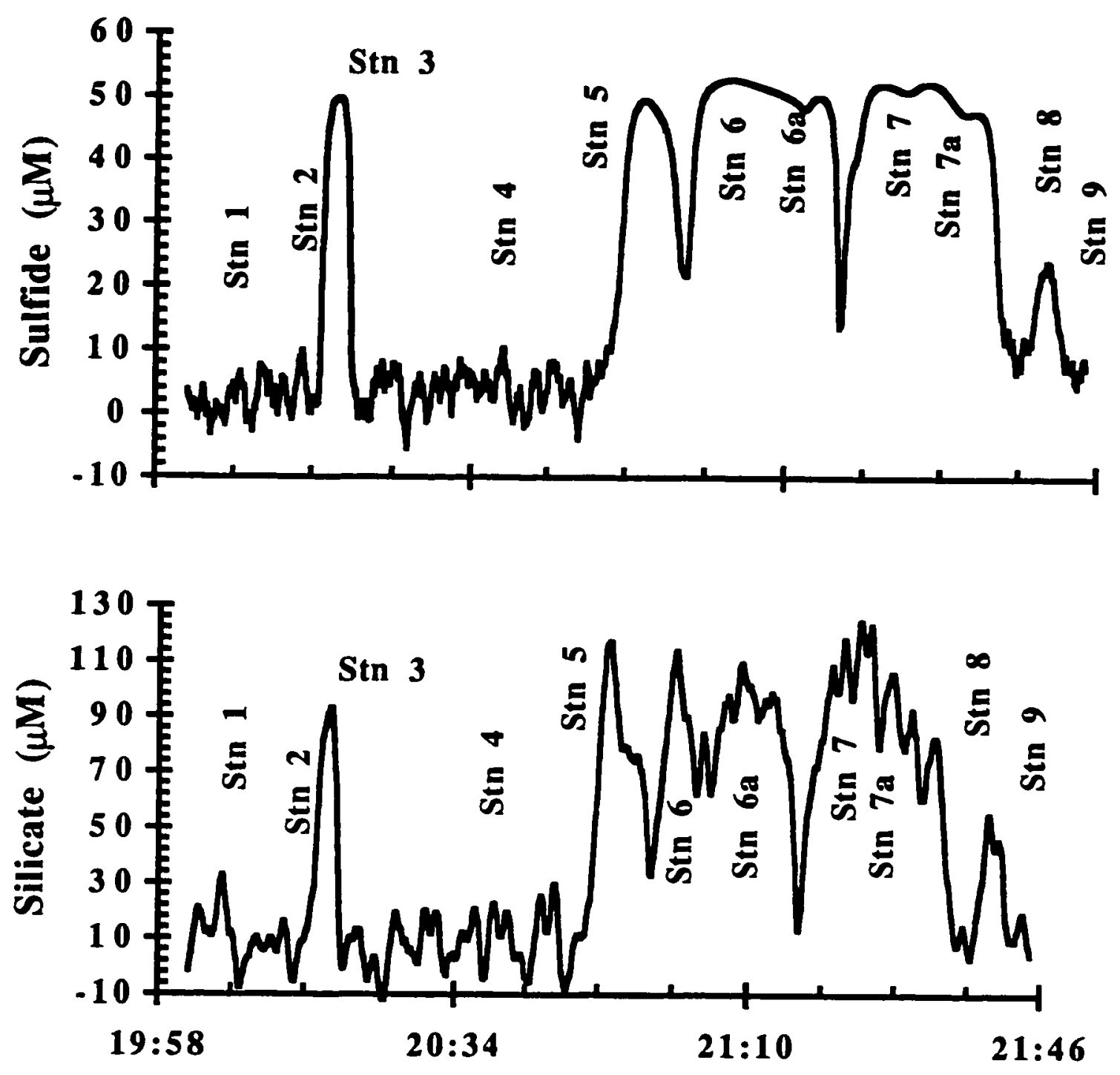

Figure 18. Timeline graph for sulfide and silicate concentrations from MBARIVentana dive 698 on January 10, 1994 at Clam Field. Stn 1: Above live clam siphons, Stn 2: Disarticulated clam site, Stn 3: Central region of bacterial mat, Stn 4: Above siphons of densely packed clams, Stn 5: Deeper (3 to $5 \mathrm{~cm}$ ) into live clams at station 4, Stn 6: Center of densely packed clams, Stn 6a: Deeper (3 to $5 \mathrm{~cm}$ ) in sediments at station 6, Stn 7: Within edge of clam site - perhaps above sediment, Stn 7a: Deeper $(3$ to $5 \mathrm{~cm}$ ) in sediments at site 7, Stn 8: $10 \mathrm{~cm}$ outside of live clam site, Stn 9: Brown sediments at AVC with live clams widely dispersed. 
The regions outside of active seep areas, Stations 1, 2, 8 and 9, showed slightly elevated concentrations of both sulfide (avg. $=7 \pm 3.6 \mu \mathrm{M}$ ) and silicate (avg. $=11 \pm 3.9 \mu \mathrm{M})$, but below concentrations found at sites of densely packed clams. The presence of slightly elevated concentrations of reduced ions suggests that the fluid charging the Clam Field site is dispersed over a wide region but is channeled to and concentrated in areas where clams congregate. The sulfide to silicate concentration graph (Figure 19) yielded a straight line indicating a constant ratio between sulfide and silicate of approximately 0.5 . The upper region of the curve shows a flattening which is characteristic of a colorimetric chemistry when absorption exceeds the optimum range.

Dives 796 \& 797: Samples for 5 stations were taken using the 6 channel SUAVE analyzer during dives 796 and 797 (Figure 20; Appendix A-2a and A-2b). Stations 1 and 5 were outside active seep regions, as identified by the lack of live clams or bacterial mat. Sulfide concentrations, at stations 1 and 5 , were 0 and $16 \mu \mathrm{M}$. Reduced iron concentrations were 2 and $94 \mu \mathrm{M}$ while $\mathrm{Mn}^{2+}$ values were 1 and $5 \mu \mathrm{M}$. Silicate varied widely from 6 to $162 \mu \mathrm{M}$. A small patch of live clams, station 2, showed unexpectedly low concentrations of sulfide at $0.3 \mu \mathrm{M}$, or essentially 0. Manganese and silicate concentrations, at this station, were also at background levels at $0.5 \mu \mathrm{M}$ and $6 \mu \mathrm{M}$ respectively, However iron concentration increased to $53 \mu \mathrm{M}$, verifying that it was an active seep region despite low concentrations of sulfide, manganese, and silicate. Station 3 was within bacterial mat at the edge of a region of live clams, and had a sulfide concentration of $26 \mu \mathrm{M}$, silicate concentration of $120 \mu \mathrm{M}$, manganese values of 4.5 $\mu \mathrm{M}$, and iron concentrations of $108 \mu \mathrm{M}$. Station 4 , located in the central region of a live clam patch, showed an increased level of sulfide, from Station 3, at $49 \mu \mathrm{M}$. Silicate levels increased coincidentally with sulfide to $209 \mu \mathrm{M}$. 
Manganese and iron concentrations decreased slightly from Station 3 to $3 \mu \mathrm{M}$ and $88 \mu \mathrm{M}$ respectively. Station $5,10 \mathrm{~cm}$ from a patch of live clams, had increased levels of all reduced ions from background concentrations found at stations 1. Manganese concentration at site 5 was similar to the concentration found at a large bacterial mat, station 3, reading $4.6 \mu \mathrm{M}$. Iron concentration at station 5 was $94 \mu \mathrm{M}$, a value between readings at Station 3 (a large bacterial mat) and station 4 (area of live clams). Sulfide concentrations were above background levels at $16 \mu \mathrm{M}$. The increased levels of measured analytes at station 5 could be a memory affect of high concentrations of analytes from previous stations and were disregarded in site to site comparison analysis. Silicate level for station 5 was $162 \mu \mathrm{M}$. which was well above background levels at station 1 of approximately $10 \mu \mathrm{M}$. The concentration data for site 5 , therefore, will not be utilized in site to site comparison analysis.

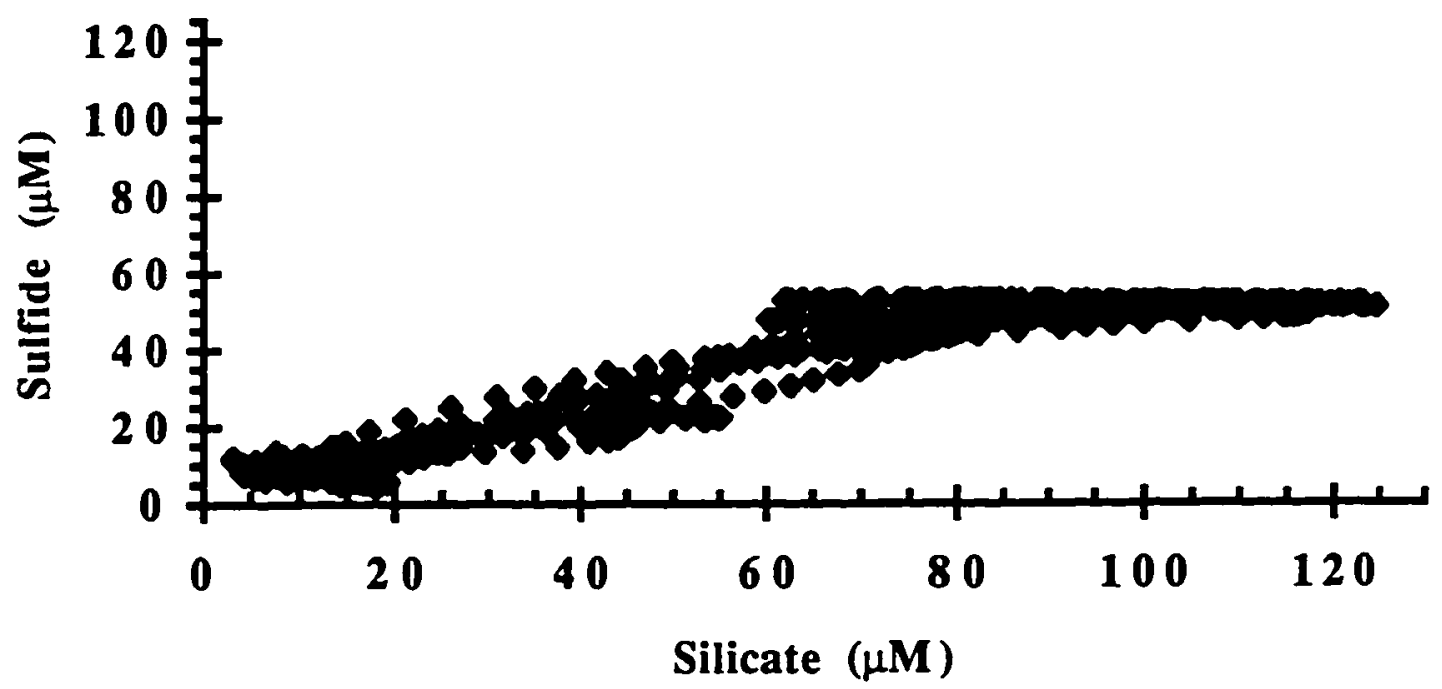

Figure 19. Sulfide concentration vs. silicate concentration at Clam Field, January 10, 1994, MBARI Ventana dive 698. Ratio of sulfide to silicate remains constant at approximately 0.6, suggesting the sulfide concentration is not generated or utilized by diagenic or biological processes. 

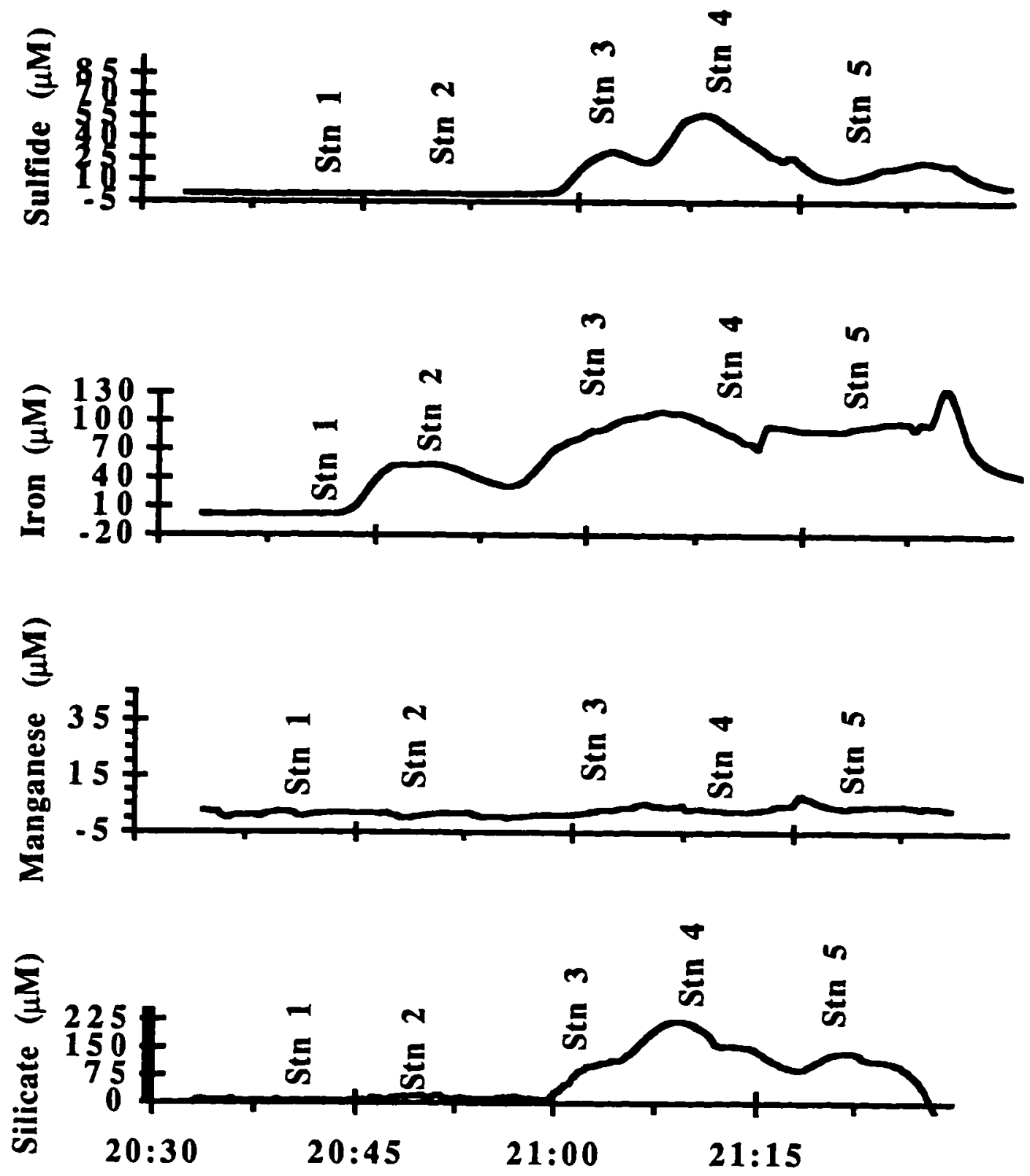

Figure 20. Timeline graph of sulfide, iron, manganese, and silicate concentrations from MBARI Ventanna dives 796 and 797, September 6, 1994 at Clam Field. Stn 1: General region without clams, Stn 2: Small seep site with live clams, Stn 3: Large bacterial mat at edge of live clams, Stn 4: Central region of live clams, $\operatorname{Stn} 5: 10 \mathrm{~cm}$ outside of live clams. 
The average concentrations for tested ions inside active seep regions were calculated using stations 3,4 , and $5(n=3)$. Average sulfide was $25 \pm 12 \mu \mathrm{M}$. Reduced iron concentrations averaged $83 \pm 14 \mu \mathrm{M} . \mathrm{Mn}^{2+}$ averaged $2.7 \pm 1 \mu \mathrm{M}$, and silicate averaged $114 \pm 49 \mu \mathrm{M}$. A single station for outside active seep regions was analyzed as described above: $s^{2-}=0.1 \mu \mathrm{M}, \mathrm{Fe}^{2+}=2.0 \mu \mathrm{M}, \mathrm{Mn}^{2+}=$ $1.0 \mu \mathrm{M}$, and $\mathrm{Si}=6.0$.

Sulfide versus silicate showed a straight curve (Figure 21a) with an average S:Si ratio of approximately 0.2 which was below the $0.5 \mathrm{~S}: \mathrm{Si}$ ratio obtained during dive 698 (Figure 19; Appendix A-1). Iron to Silicate (Figure 21b) yielded two straight curves where silicate remained approximately at ambient sea water levels and iron increased to a maximum value of $90 \mu \mathrm{M}$. The iron concentration then leveled off and silicate concentrations increased to its maximum value of about $200 \mu \mathrm{M}$. This behavior indicates a large iron increase that was not associated with the sulfide concentration increase, as seen at station 2 (Figure 20). This may reflect a lateral gradient in redox conditions around the seep sites, with $\mathrm{Fe}^{2+}$, but no $\mathrm{S}^{2-}$, at intermediate distances from the seep. The manganese to silicate graph (Figure 21c) showed a weak increase in Mn that correlated with an increase in silicate.

Dive 806: Twenty samples were taken in rapid succession by the 6 channel SUAVE analyzer during dive 806 (Figure 22; Appendix A-3). Silicate and iron channels did not function during this dive preventing the determination of ion to silicate ratios. Outside regions of active seeping (i.e., brown sediment with no live clams or bacterial mat at stations $1,3,9$ to 14 , and 18 to 20) sulfide concentrations ranged from below detection limits to $20 \mu \mathrm{M}$. The higher levels of sulfide, 5 to $20 \mu \mathrm{M}$, were associated with dark sediment with no live clams or bacterial mats (Stations 18 to 20 ) and were immediately 


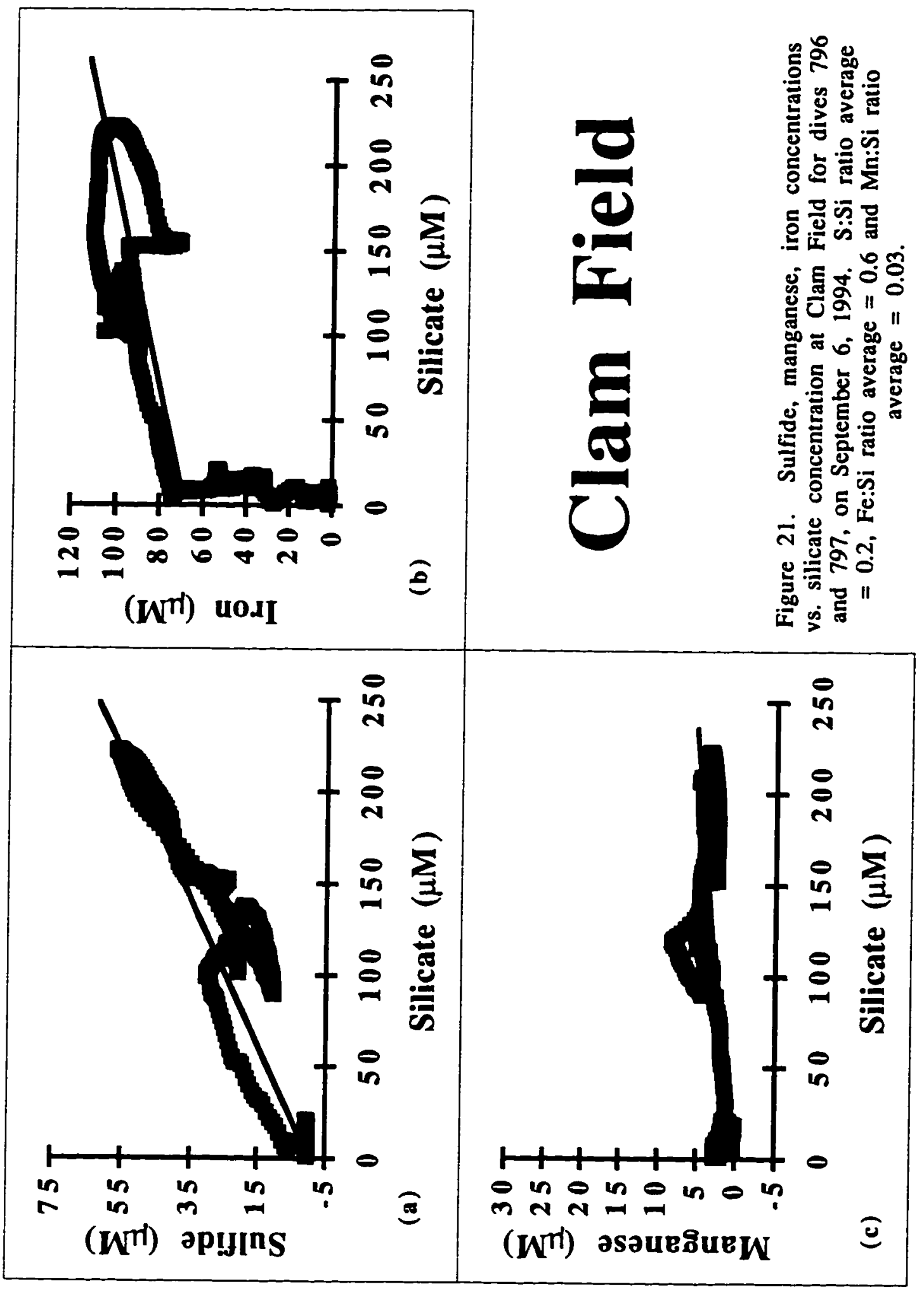



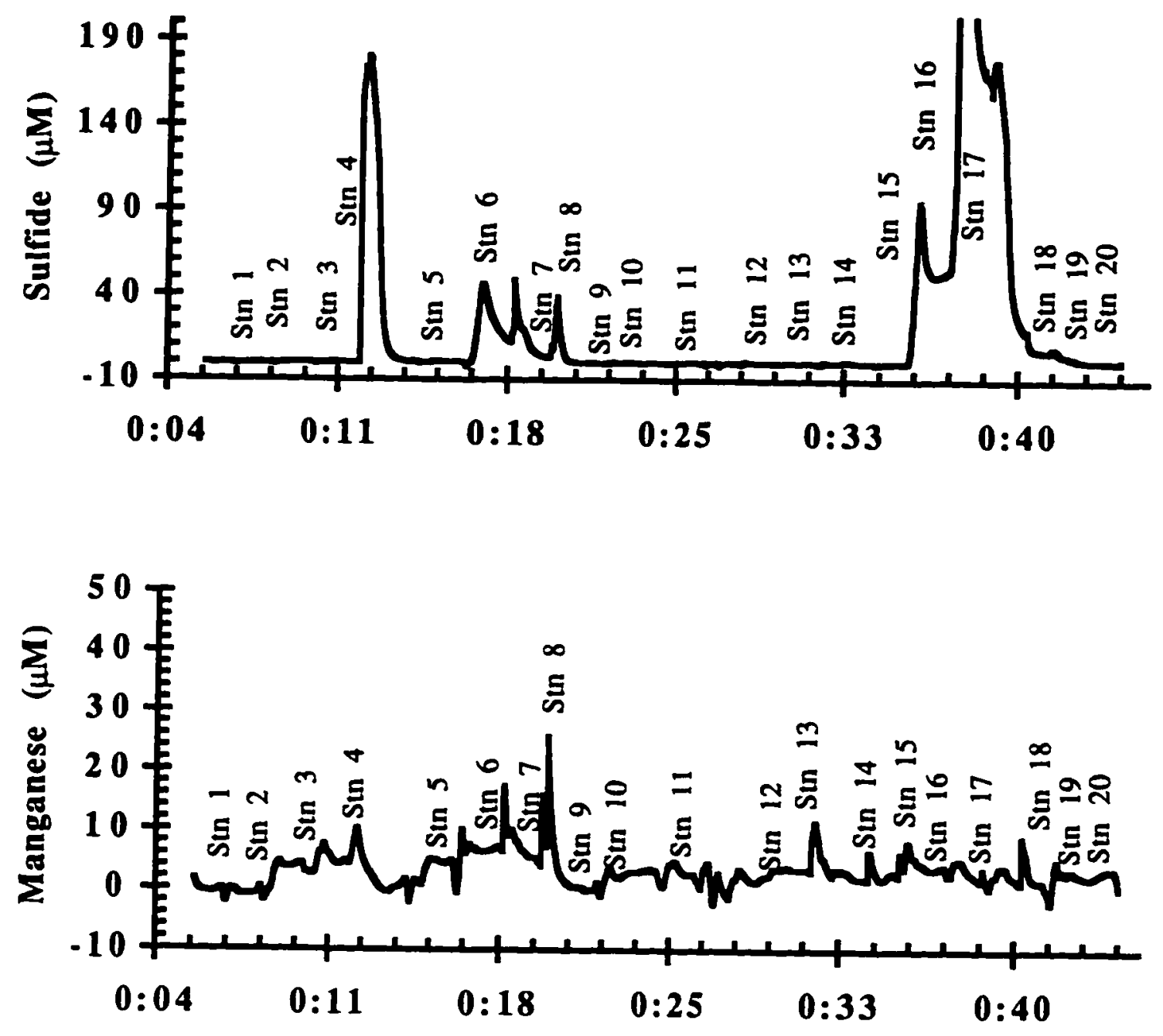

Figure 22. Timeline graph of sulfide and manganese concentrations from MBARI Ventana dive 806 at Clam Field on September 26, 1994. Stn 1: $10 \mathrm{~cm}$ from bacterial mat, Stn 2: Edge of bacterial mat, $\operatorname{Stn} 3: 7 \mathrm{~cm}$ from bacterial mat, Stn 4: Center of bacterial mat, Stn 5: Edge of live clams, Stn 6: Inside live clam region, Stn 7: Inside live clam region, $\operatorname{Stn}$ 8: Inside live clam region, $\operatorname{Stn} 9$ :

Outside seep region - no bacterial mat or live clams, Stn 10: Outside seep region, Stn 11: Dark sediments with disarticulated shell, Stn 12: Dark sediment with disarticulated shells, Stn 13: Dark sediments with articulated shell, Stn 14: Above dark sediment, Stn 15: Live clam seep, Stn 16: Central live clam seep, Stn 17: Central live clam seep, Stn 18: Outside live clams, Stn 19: Dark sediments outside seep, Stn 20: Dark sediments. 
sampled after the highest concentration recorded at station 17 . These readings may have been affected by the high sulfide muds of station 17 adhering to the intake filter and causing inaccurate readings. Discarding the sulfide readings of stations 18 and 19, then the maximum concentration of sulfide outside active seep sites was $5.3 \mu \mathrm{M}$. The average sulfide concentration for outside seep regions was $1.2 \pm 0.3 \mu \mathrm{M}$, while the average manganese concentration was $2.6 \pm$ $0.5 \mu \mathrm{M}(\mathrm{n}=9)$.

Samples taken at the edge of bacterial mats and live clam groupings, stations 2 and 5 , showed sulfide concentrations ranging from below detection limit to approximately $2 \mu \mathrm{M}$. Manganese concentrations at these sites were essentially zero. The highest levels of sulfide, 52 to $208 \mu \mathrm{M}$, were in the central regions of live clam patches (stations 16 to 17). The sulfide concentration at station 4 , in the central region of a bacterial mat, was $174 \mu \mathrm{M}$. Stations 7 and 8 were also located inside live clam regions but yielded much lower sulfide concentrations at 45 and $35 \mu \mathrm{M}$. The maximum concentration of manganese, $11 \mu \mathrm{M}$, was recorded at station 8. One reading, station 5, was taken at the edge of a live clam patch and yielded $2 \mu \mathrm{M}$ sulfide and negligible manganese. Manganese concentrations in live clam sites (station 6 to 8 and 15 to 17) vary from below detection limits to $36 \mu \mathrm{M}$. The highest manganese reading, $36 \mu \mathrm{M}$ at station 8, is coincidental with a moderate sulfide level of $50 \mu \mathrm{M}$. Average inside seep concentration for sulfide was $87 \pm 13$ and for manganese was $5.7 \pm 0.6 \mu \mathrm{M}$ $(n=7)$ for dive 806 were calculated using stations 4,6 to 8 , and 15 to 17 . Outside average concentrations were calculated using stations $1,3,9$ to 14 , and 20 was $1.2 \pm 0.3 \mu \mathrm{M}$ sulfide and $2.6 \pm 0.5 \mu \mathrm{M}(\mathrm{n}=9)$. 


\section{Overview}

All data collected at the Clam Field site were collated into a table of concentrations divided into sample types: Above (in the water column, $\leq 3 \mathrm{~cm}$ above clam siphons), outside, at the edge of, and central regions of active seep regions. Maximum and average concentrations inside and outside active seeps and their standard errors were also provided (Table 9). It was found that the maximum concentrations of ions at active seep sites at Clam Field were $208 \mu \mathrm{M}$ sulfide, $108 \mu \mathrm{M}$ iron, $11 \mu \mathrm{M}$ manganese, and $209 \mu \mathrm{M}$ silicate (Table 10). Ambient sea water values of silicate calculated to be $110 \pm 10 \mu \mathrm{M}$ (Table 6), yielded a maximum total silicate value in sediment of $319 \pm 10 \mu \mathrm{M}$. The average values (Table 9 and 10) for concentrations within the active seep regions of Clam Field were $59 \pm 3.8 \mu \mathrm{M}$ sulfide, $83 \pm 14 \mu \mathrm{M}$ iron, $4.8 \pm 0.4 \mu \mathrm{M}$ manganese, and 108 $\pm 6.3 \mu \mathrm{M}$ silicate. Outside active seeps, where no live clams or bacterial mats were found, concentrations dropped to maximum concentrations of $23 \mu \mathrm{M}$ sulfide, $2 \mu \mathrm{M}$ iron, and $10 \mu \mathrm{M}$ silicate (Table 10). The outside $\mathrm{Mn}^{2}+$ concentration range of 0 to approximately $10 \mu \mathrm{M}$, was equivalent to inside active seep regions at Clam Field. Average concentrations outside active seep regions at Clam Field were $3.2 \pm 0.6 \mu \mathrm{M} \mathrm{S}^{2-}, 2 \mu \mathrm{M} \mathrm{Fe}{ }^{2+}, 2.8 \pm 0.3 \mu \mathrm{M} \mathrm{Mn}^{2+}$, and $7.3 \pm 1.2$ Si $\mu \mathrm{M}$.

Dispersed and diffuse fluid flow was suggested by concentrations of sulfide. reduced iron, reduced manganese, and silicate elevated above background in outside seep regions. Focusing of deep sediment fluids though specific conduits, such as fractured rock was evident in station 1 of dive 806 , where concentrations of sulfide and manganese dropped to background levels within $10 \mathrm{~cm}$ of an active secp region. 
Table 9. Location of sample relative to active seep region and concentrations of $\mathrm{S}^{2-}, \mathrm{Fe}^{2+}, \mathrm{Mn}^{2+}$, and silicate determined at Clam Field. Dives 796, 797 station 5 and dive 806 stations 18 and 19 were not used in averages due to the possible memory effect of high ion concentrations at the previous station. Locations 3 to 14 were used to calculate outside average and locations 18 to 33 were used to calculate inside average, standard error indicated by " \pm ". Bold numbers are maximum values, underline numbers are minimum values. "-" implies no data.

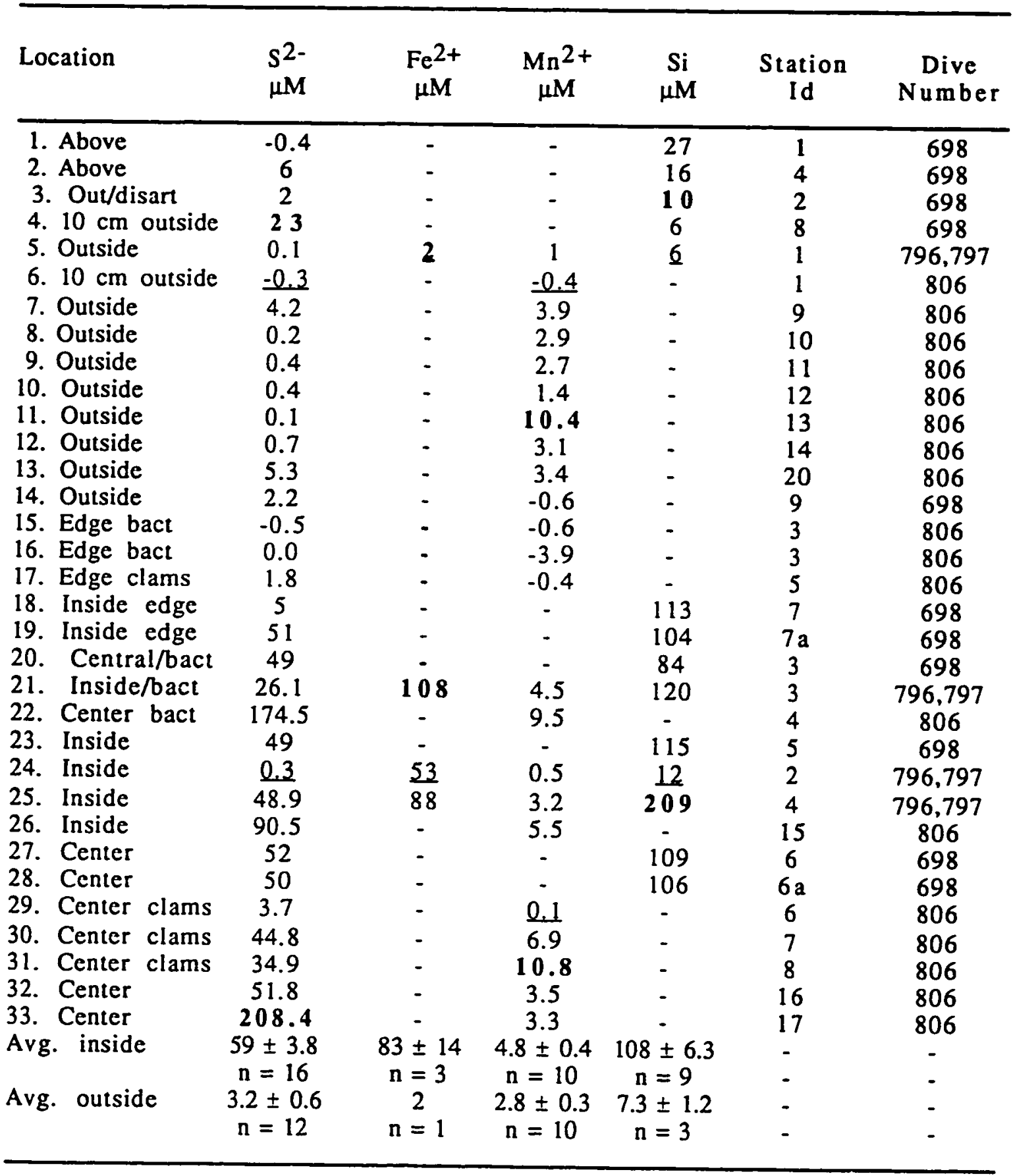


Table 10. Clam Field minimum, maximum, and average concentrations of the ions $\mathrm{S}^{2-}, \mathrm{Fe}^{2+}, \mathrm{Mn}^{2+}$, and silicate for inside and outside active seep sites. All concentrations are reported in micromolar units. "-" indicates no data.

\begin{tabular}{cccccccc}
\hline I on & \multicolumn{3}{c}{ Inside Seep $-\mu M$} & \multicolumn{3}{c}{ Outside Seep - $\mu M$} \\
& Min. & Max. & Avg. & Min. & Max. & Avg. \\
& & & & & & & \\
\hline $\mathrm{S}^{2-}$ & 0.3 & 208 & $59 \pm 3.8$ & 0 & 23 & $3.2 \pm 0.6$ \\
$\mathrm{Fe}^{2+}$ & 53 & 108 & $83 \pm 14$ & - & 2 & - \\
$\mathrm{Mn}^{2+}$ & 0.1 & 11 & $4.8 \pm 0.4$ & 0 & 10 & $2.8 \pm 0.3$ \\
$\mathrm{Si}$ & 12 & 209 & $108 \pm 6.3$ & 6 & 10 & $7.3 \pm 1.2$ \\
Total Si & 122 & 319 & $218 \pm 10$ & 116 & 120 & $117 \pm 10$ \\
\hline
\end{tabular}

\section{MUD VOLCANO}

Mud Volcano, also known as Clam Flat site (Barry et. al, submitted a), is located on Smooth Ridge at approximately $36^{\circ} 44^{\prime} 44^{\prime \prime} \mathrm{N}, 122^{\circ} 16^{\prime} 40^{\prime \prime} \mathrm{W}$ in 1000 meters of water (Figure 17). Smooth Ridge is an uplifted portion of the continental slope located west of the Palo Colorado-San Gregorio fault zone and Monterey Bay, thus the basement is thought to be consolidated to semiconsolidated sedimentary rock as well as volcanic rock overlaid by bedded shale (Greene, 1977). This region supports numerous communities of chemosynthetic organisms. Distinctive features of the site are circular areas of high reflectivity, large carbonate deposits, and rare pock marks (Orange et al., submitted a; Martin et al., submitted; Stakes et al., submitted).

Biological communities are located in aggregations, 0.25 to $10 \mathrm{~m}^{2}$, primarily of C. kilmeri clams, the bacterial mat Beggiatoa sp., and associated organisms. The predominant aggregation of $C$. kilmeri, at the site analyzed, occur at the base of a small 1 meter scarp forming a band of active seep area. The region 
surrounding the seeps occurs typically at smooth sediment with scattered carbonate blocks on a $1^{\circ}$ slope (Barry et al., submitted a).

\section{Scanner Data}

Data at the Mud Volcano were obtained during three Ventana dives: MBARI dive 699 on January 11, 1994; 800 on September 13, 1994; and 803 on September 20, 1994 (Appendix A-4 to A-6b).

Dive 699 utilized the SCANNER to analyze sulfide and silicate. The silicate chemistry did not function during dive 699. Sulfide concentrations were determined at 5 stations (Figure 23; Appendix A-4). Station 1 (above the clam siphons in the water column) and station 4 (0.5 meters from live clams) showed ambient sea water levels of sulfide of 0 and $0.2 \mu \mathrm{M}$ which were essentially below detection limits of the instrument. Sites associated with active seep regions, stations 2, 3, and 5, had sulfide concentrations ranging from 12 to $21 \mu \mathrm{M}$. Station 5, at the edge of a live clam patch, has the lowest concentration of sulfide for an active region at $12 \mu \mathrm{M}$. The maximum value of $21 \mu \mathrm{M}$ sulfide, at station 3, was associated with the center of a live clam patch.

Dive 800: The SUAVE analyzer was used during dive 800 to analyze sulfide, iron, manganese, and silicate at 2 stations (Figure 24; Appendix A-5). Iron and silicate chemistry did not function during dive 800 . Sulfide and manganese concentrations for station 1 , located $15 \mathrm{~cm}$ from an active seep region, were at background levels, at 0 . Station 2 was central to a clam patch and sulfide concentration reached $52 \mu \mathrm{M}$, while manganese measured slightly above background level at $0.5 \mu \mathrm{M}$.

Dive 803: The SUAVE analyzer was used during the final dive, 803, at Mud Volcano to test fluids at 8 stations (Figure 25; Appendix A-6a and 6-b). Stations 1 and $2,15 \mathrm{~cm}$ and $250 \mathrm{~cm}$ from an active scep region, showed elevated 


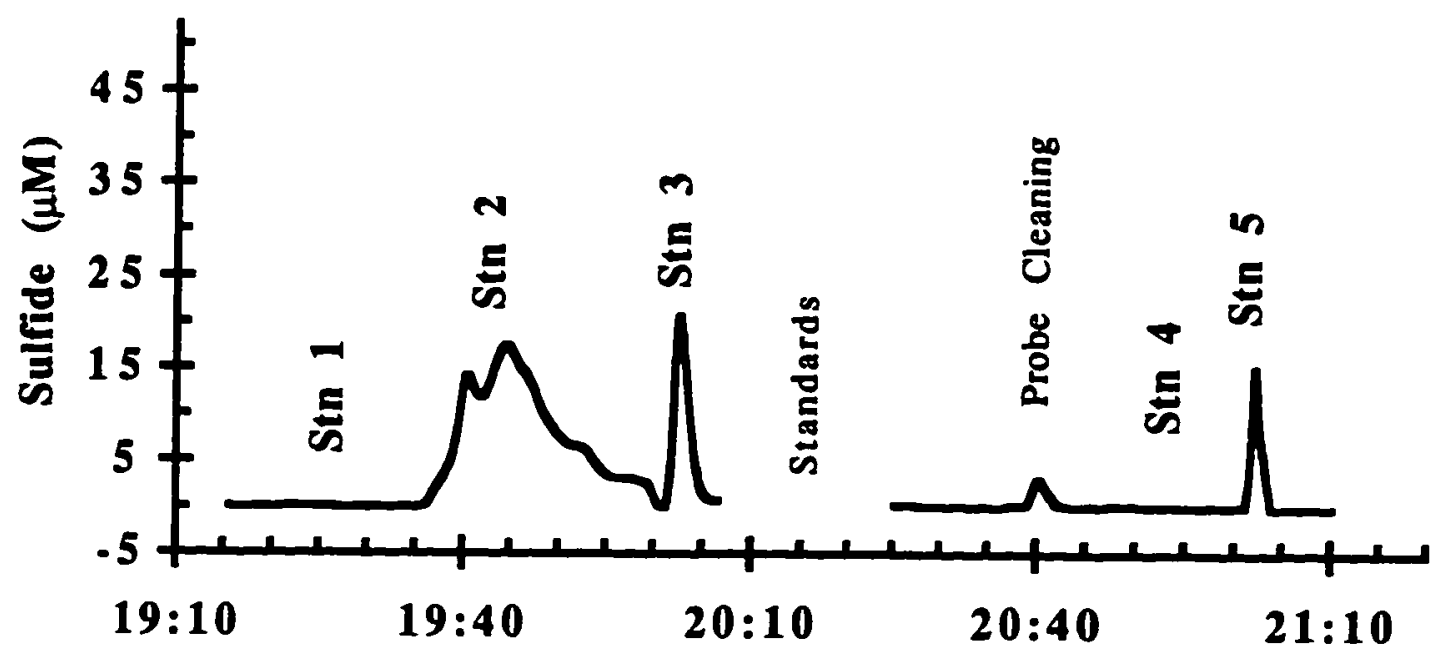

Figure 23. Timeline graph of sulfide concentrations from MBARI Ventana dive 699 at Mud Volcano, January 11, 1994. Stn 1: Fluids above clam siphons, Stn

2: Sediments surrounded by clams, Stn 3: Central area of clams, Stn 4: 0.5 meters from clams, Stn 5: Edge of clams.
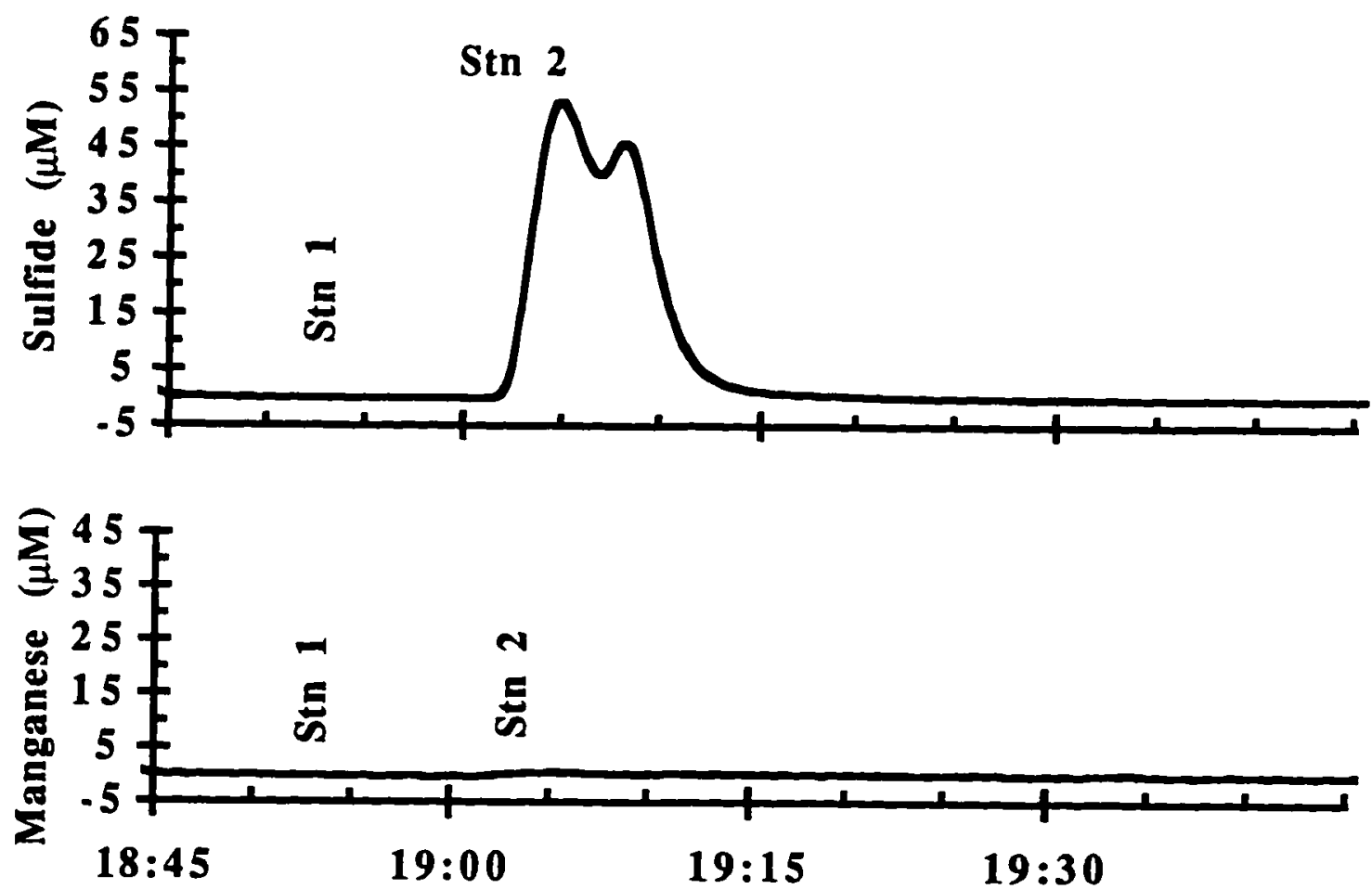

Figure 24. Timeline graph of sulfide and manganese concentrations for MBARI Ventana dive 800 at Mud Volcano, September 13, 1994. Stn 1: $15 \mathrm{~cm}$ from the edge of live clams, Stn 2: Central region of live clams. 

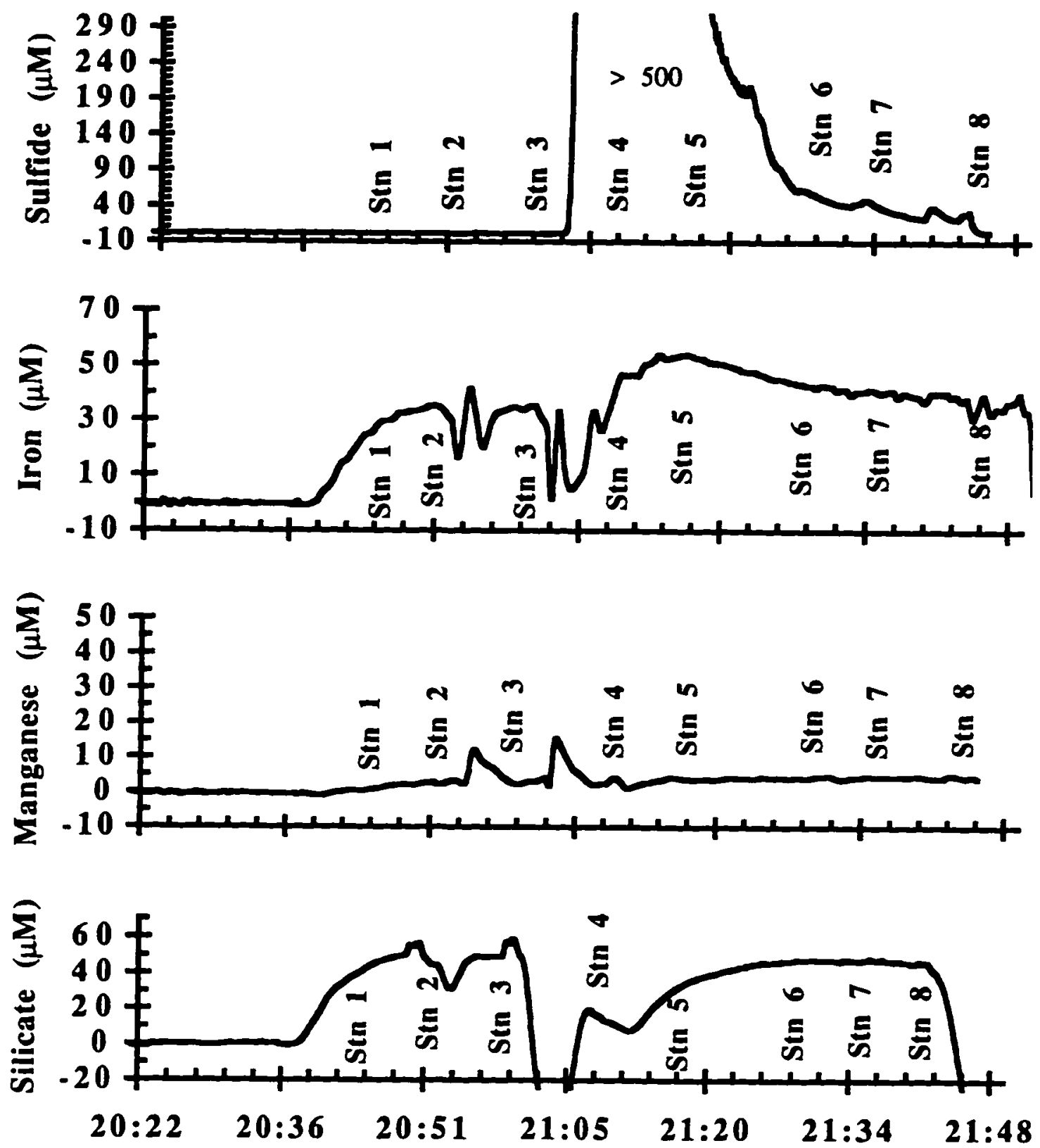

Figure 25. Timeline graph from sulfide, iron, manganese, and silicate concentrations for MBARI dive 803 of September 20, 1994 at Mud Volcano. Stn 1: $15 \mathrm{~cm}$ from live clams, Stn 2: $2.5 \mathrm{~m}$ from live clams, Stn 3: Central region of clams - brown sediments, Stn 4: Central region of live clams, Stn 5:

$8 \mathrm{~cm}$ from clams, $S t n$ 6: $20 \mathrm{~cm}$ from clams, $S t n$ 7: $3 \mathrm{~m}$ from clams, Stn 8: Scattered disarticulated shells. 
concentrations of iron, 23 and $35 \mu \mathrm{M}$, and silicate, 38 and $55 \mu \mathrm{M}$. Manganese at station 1 was at background levels, $0.4 \mu \mathrm{M}$, but increased to $2.6 \mu \mathrm{M}$ at station 2 . Sulfide concentrations were constant at $1.7 \mu \mathrm{M}$. Station 3 was within a small live clam site, and yielded low readings of sulfide of about $2 \mu \mathrm{M}$ and manganese concentration was about $2.3 \mu \mathrm{M}$. The iron and silicate concentrations, 34 and $57 \mu \mathrm{M}$ respectively, were similar to concentrations recorded at station 2 . Station 4, located within the dark sediment of a live clam patch, yielded sulfide concentrations within the upper detection limit of the instrument at $>500 \mu \mathrm{M}$. Iron concentration increased to $47 \mu \mathrm{M}$ while manganese levels decreased to $1.3 \mu \mathrm{M}$. Silicate concentrations decreased to $9 \mu \mathrm{M}$ above ambient sea water levels. The concentrations of all ions for station 5 through 8 appeared affected by the very high sulfide and iron concentrations found at station 4 . Station 5 was located $8 \mathrm{~cm}$ from a live clam batch however the concentration of sulfide recorded increased. Iron and manganese followed the same trend with iron increasing to $53 \mu \mathrm{M}$ and manganese increasing to $4 \mu \mathrm{M}$. Manganese concentrations continued to increase from station 6 to station 8 . Sulfide and iron concentrations drop in a consistent and steady fashion (Figure 25). Sulfide concentrations at station 6,7 and 8 were 82,31 , and $27 \mu \mathrm{M}$, respectively, while iron concentrations were 45,41 , and $38 \mu \mathrm{M}$ for the last three stations. Thus the data recorded for sites 5 to 8 was discarded in the later discussions.

Sulfide, iron, and manganese concentrations plotted against silicate concentrations from dive 803 (Figure 26; Appendix A-6) provided no recognizable patterns. This lack of a defined curve and relationship of ions to silicate concentrations is attributed to the overwhelming signal of sulfide and iron at station 4 as well as the relatively stable concentrations of manganese. 


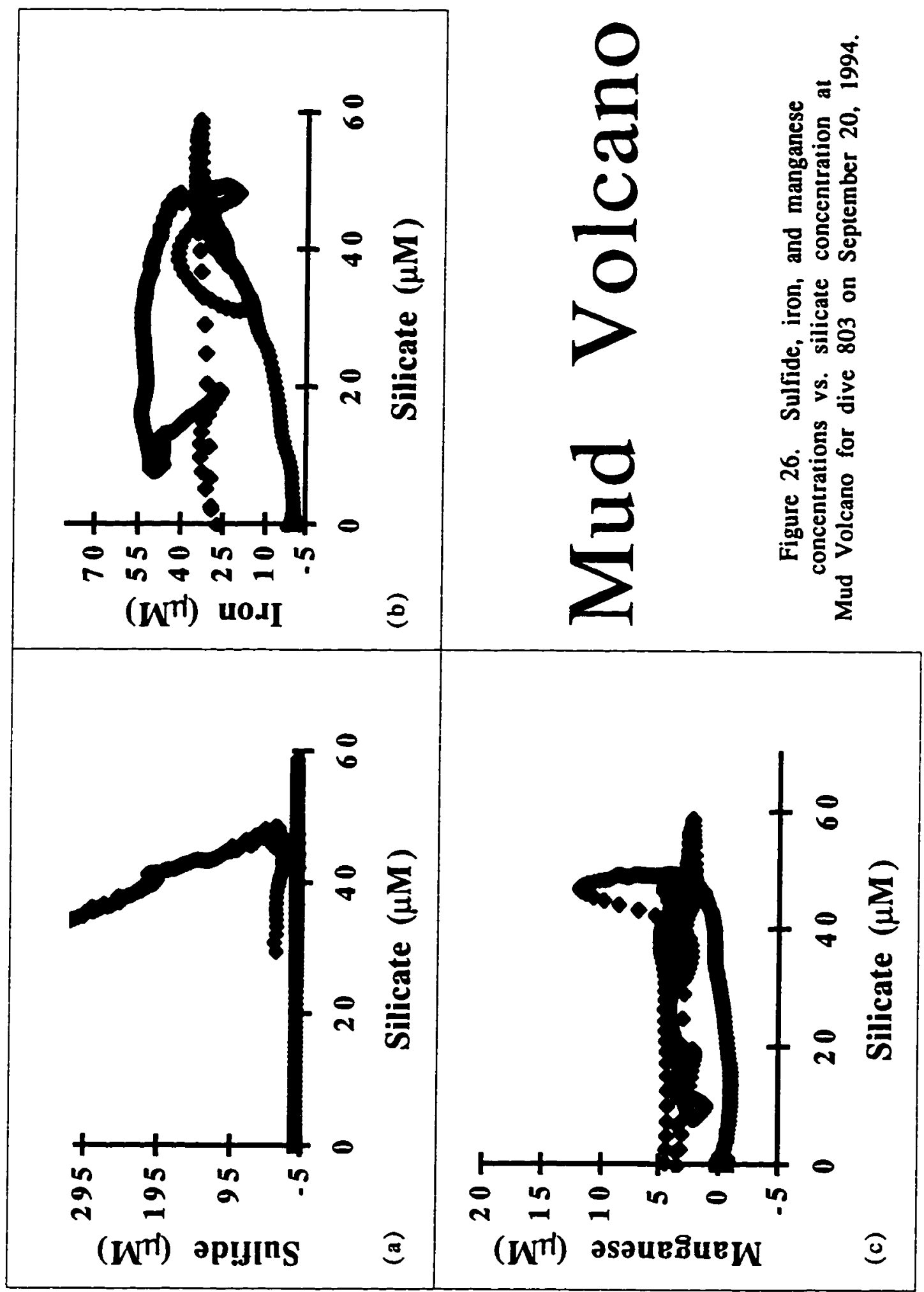


The ratio of sulfide to silicate ( $\mathrm{S}: \mathrm{Si}$ ) varied widely between active seep region, station 4 , and outside active seeps, station 1 . Inside the seep the $S: S i$ ratio was approximately 80 while outside seep regions was at 0.4 . Iron showed a similar pattern of high Fe:Si ration of 53 in the active seeps, to the low 0.6 Fe:Si ratio outside active seeps. Manganese showed an order of magnitude difference from a $\mathrm{Mn}: \mathrm{Si}$ ratio of 0.01 outside seeps to 0.1 inside the seep.

\section{Overview}

All data collected from the Mud Volcano site were collated into a table of concentrations found above active seep sites in the water column, outside active seep site, at the edge of active seep sites, central regions of active seep sites, and maximum and average concentrations inside and outside active seeps (Table 11).

The maximum values of measured ions at active seep sites were $>500 \mu \mathrm{M}$ sulfide, about $50 \mu \mathrm{M}$ iron, $2 \mu \mathrm{M}$ manganese, and approximately $60 \mu \mathrm{M}$ silicate above the ambient sea water level (Table 12). Outside active seep regions at the Mud Volcano sulfide maximized at $2 \mu \mathrm{M}$, iron at $35 \mu \mathrm{M}$, manganese at $3 \mu \mathrm{M}$, and silicate at $55 \mu \mathrm{M}$ (Table 12).

The surprisingly high sulfide, $>500 \mu \mathrm{M}$, concentration at site 4 of dive 803 reflected the millimolar levels reported by Barry et al. (submitted a) and determined by Dr. R. Kochevar (personal communication, 1995) suggesting an anoxic environment with deep interstitial fluid moving to the sediment-water interface as expected. Silicate levels ranged from 0 to $57 \mu \mathrm{M}$ above ambient sea water levels and are equivalent to silicate concentrations in non-seep regions suggesting a deep fluid source that lacks biogenic opal required for elevated concentrations. Iron concentrations, in active seep regions, were higher 
than in non-seep areas suggesting that the reduction of iron oxides to $\mathrm{Fe}^{2+}$ proceeds more quickly than the precipitation to iron sulfides, which was unexpected. Manganese concentration ranges are similar in non-seep or active seep regions and do not show wide variances.

Outside active seep areas (Tables 11 and 12), sulfide concentrations ranged from below detection limits to approximately $2 \mu \mathrm{M}$. Stations 5 through 8 of dive 803 showed unexpectedly high sulfide concentrations $(27$ to above the detection limit), for outside active seep areas and were assumed to be anomalous readings associated with a memory effect of a high sulfide concentration at station 4 . Stations 5 through 8 for dive 803, showed high, 38 to $45 \mu \mathrm{M}$, concentrations of iron which were probably anomalous as discussed above. Adjusting for this erroneously high iron level, the maximum concentration of iron for outside seep regions was $35 \mu \mathrm{M}$ with an average value of $29 \pm 8.3 \mu \mathrm{M}$. Manganese concentrations outside active seeps ranged from below the detection limit to $2.6 \mu \mathrm{M}$. Stations 5 through 8 from dive 803 , again, showed high manganese concentrations averaging about $5 \mu M$. Discarding stations 5 to 8 of dive 803, the average $\mathrm{Mn}^{2+}$ concentration at Mud Volcano was $1.5 \pm 1.5(\mathrm{n}=2)$ for outside active seep regions. Silicate concentrations, outside active seep regions, ranged from background levels at $0 \mu \mathrm{M}$ to about $55 \mu \mathrm{M}$ above ambient sea water values which was equivalent to the range of silicate in non-seep regions. 
Table 11. Concentrations of sulfide, iron, manganese, and silicate determined at Mud Volcano. Stations 5 through 8 from dive 803 was removed from averages due to the possible memory effect high ion concentrations at the previous station. Inside averages were calculated using locations 7 to 11 and outside averages were calculated using location 2 to 5 . Standard error indicated by " \pm " value, bold numbers are maximum values, and underlined numbers are minimum values. "-" implies no data.

\begin{tabular}{lcccccc}
\hline Location & $\begin{array}{c}\mathrm{S}^{2-} \\
\mu \mathrm{M}\end{array}$ & $\begin{array}{c}\mathrm{Fe}^{2+} \\
\mu \mathrm{M}\end{array}$ & $\begin{array}{c}\mathrm{Mn}^{2+} \\
\mu \mathrm{M}\end{array}$ & $\begin{array}{c}\mathrm{Si} \\
\mu \mathrm{M}\end{array}$ & $\begin{array}{c}\text { Station } \\
\text { Id }\end{array}$ & $\begin{array}{c}\text { Dive } \\
\text { Number }\end{array}$ \\
\hline 1. Above & 0 & - & - & - & 1 & 699 \\
2. Outside & 0.2 & - & - & - & 4 & 699 \\
3. Outside & -0.01 & - & - & -0.2 & 1 & 800 \\
4. Outside & 1.7 & $\underline{23.0}$ & $\underline{0.4}$ & 38.2 & 1 & 803 \\
5. Outside & 1.7 & $\mathbf{3 4 . 8}$ & $\mathbf{2 . 6}$ & $\mathbf{5 5 . 1}$ & 2 & 803 \\
6. Edge & 12 & - & - & - & 5 & 699 \\
7. Inside & 17 & - & - & - & 2 & 699 \\
8. Inside & 21 & - & - & - & 3 & 699 \\
9. Inside & 52.3 & - & - & 0.5 & 2 & 800 \\
10. Inside & $\mathbf{1 . 8}$ & $\mathbf{3 4 . 0}$ & $\mathbf{2 . 3}$ & $\mathbf{5 7 . 4}$ & 3 & $\mathbf{8 0 3}$ \\
11. Inside & $\mathbf{7 7 7 . 1}$ & $\mathbf{4 6 . 4}$ & 1.3 & 9.3 & 4 & 803 \\
Avg. inside & $174 \pm 84$ & $40 \pm 8.8$ & $1.8 \pm 0.7$ & $22 \pm 15$ & - & - \\
& $\mathrm{n}=5$ & $\mathrm{n}=2$ & $\mathrm{n}=2$ & $\mathrm{n}=3$ & - & - \\
Avg. outside & $0.9 \pm 0.3$ & $29 \pm 8.3$ & $1.5 \pm 1.5$ & $31 \pm 14.1$ & - & - \\
& $\mathrm{n}=4$ & $\mathrm{n}=2$ & $\mathrm{n}=2$ & $\mathrm{n}=3$ & - & - \\
\hline
\end{tabular}

Table 12. Mud Volcano minimum, maximum, and average concentrations of $\mathrm{S}^{2-}, \mathrm{Fe}^{2+}, \mathrm{Mn}^{2+}$, and silicate for inside and outside active seep sites. All concentrations are reported in micromolar units. Standard error indicated by " $\pm "$ value.

\begin{tabular}{|c|c|c|c|c|c|c|}
\hline \multirow[t]{2}{*}{ I on } & \multirow{2}{*}{\multicolumn{3}{|c|}{$\begin{array}{cc}\text { Inside } & \text { Seep }-\mu M \\
\text { Min. } & \text { Max. Avg. }\end{array}$}} & \multicolumn{3}{|c|}{ Outside Seep - $\mu \mathrm{M}$} \\
\hline & & & & Min. & Max. & Avg. \\
\hline$s^{2-}$ & 2 & $>500$ & $174 \pm 84$ & 0 & 2 & $0.9 \pm 0.3$ \\
\hline $\mathrm{Fe}^{2+}$ & 35 & 46 & $40 \pm 8.8$ & 23 & 35 & $29 \pm 8.3$ \\
\hline $\begin{array}{c}\mathrm{Mn}^{2+} \\
\mathrm{Si} \\
\text { Total Si}\end{array}$ & $\begin{array}{c}1 \\
0 \\
120\end{array}$ & $\begin{array}{c}2 \\
57 \\
177\end{array}$ & $\begin{array}{c}1.8 \pm 0.7 \\
22 \pm 15 \\
142 \pm 15\end{array}$ & $\begin{array}{c}0 \\
0 \\
120\end{array}$ & $\begin{array}{c}3 \\
55 \\
175\end{array}$ & $\begin{array}{c}1.5 \pm 1.5 \\
31 \pm 14.1 \\
151 \pm 14\end{array}$ \\
\hline
\end{tabular}




\section{MOUNT CRUSHMORE}

Mount Crushmore (Figure 17) is located six kilometers north of the Clam Field location at $36^{\circ} 47^{\prime} 05^{\prime \prime} \mathrm{N}, 122^{\circ} 02^{\prime} 36^{\prime \prime} \mathrm{W}$, in 620 meters of water. The Mount Crushmore site is located at the mouth of the Soquel Canyon east of the Monterey Bay Fault zone. The general topography is a steep outcrop with a 30 to $40^{\circ}$ slope (Barry et al., submitted a). Seep sites are small at approximately $0.5 \mathrm{~m}^{2}$ and are found at cracks within the outcrop following a $1 \mathrm{~km}$ long band (Barry et al., submitted a). The Purisima Formation, established as a ground water bearing structure, is the underlying geologic unit at the Mount Crushmore site (Sullivan, 1994). Mount Crushmore is located east of the Palo Colorado-San Gregorio fault zone, thus the basement is the granitic Salinian block.

The biological community at Mount Crushmore is characterized by orange and white bacterial mat and the clam $C$. pacifica. Bacterial mats encrust areas of dark sediment as well as mega-fauna (Barry et al., submitted a) and surround some obvious fissures in the canyon wall.

\section{Scanner Data}

Mount Crushmore was inspected twice on August 12, 1994, dive 787, and August 18, 1994, dive 790 (Appendix A-7 to A-8b).

Dive 787 yielded seven samples using the SUAVE analyzer (Figure 27; Appendix A-7). The iron and silicate chemical channels were not functioning during this dive. Clams were absent at stations 3 and 6 which were characterized by brown sediment. At these 2 outside stations, sulfide concentrations were approximately background levels averaging $0.3 \pm 1.4 \mu \mathrm{M}(\mathrm{n}=$ 2). Manganese concentrations ranged from 0.1 to $0.9 \mu \mathrm{M}$. The region at the 
edge of clams (station 7) held similar concentrations of $\mathrm{S}^{2-}$ and $\mathrm{Mn}^{2+}$ to stations 3 and 6 at $0.2 \mu \mathrm{M}$ and $0.6 \mu \mathrm{M}$ respectively. Stations 1 and 2 were brief encounters with dark sediment while clams were collected. Sulfide, at these stations ranged from 1.3 to $2.5 \mu \mathrm{M}$, while $\mathrm{Mn}^{2+}$ ranged from 1.9 to $2.4 \mu \mathrm{M}$. These reading show increased reduced ions at sites of live clams but were discarded for comparison with other sites because of the inconsistent manner in which they were collected. Station 5 was an area with occasional live clams, some patches of dark sediment, and scattered disarticulated shells. The $\mathbf{S}^{2}$ concentration for station 5 was approximately $4 \mu \mathrm{M}$ and $\mathrm{Mn}^{2+}$ concentration was $1.2 \mu \mathrm{M}$. The single sample taken in the central region of a live clam site, station 4, showed higher levels of sulfide at about $31 \mu \mathrm{M}$. Manganese at station 4 was $0.5 \mu \mathrm{M}$. well below levels measured at stations 1 and 2 .

The highest concentration of manganese, $2.4 \mu \mathrm{M}$, was found at station 1 where the sampling probe touched the upper layer of sediment for a brief period. Similarly, the manganese concentration for station 2 was also elevated from background at $1.9 \mu \mathrm{M}$. Both stations 1 and 2 had relatively low concentrations of sulfide, 2.5 and $1.3 \mu \mathrm{M}$ respectively, possibly due to oxidation of sulfide in the upper most layers of sediment.

Elevated concentrations of manganese (i.c., $2.4 \mu \mathrm{M}, 1.9 \mu \mathrm{M}$, and $0.9 \mu \mathrm{M}$ ) were found at seep sites indicated by slightly increased values of sulfide (i.e., $2.5 \mu \mathrm{M}$, $1.3 \mu \mathrm{M}$, and $4.4 \mu \mathrm{M})$. However, the lowest concentration of manganese, $0.5 \mu \mathrm{M}$, was found at an active secp and was associatcd with the highest level of sulfide, $31 \mu \mathrm{M}$, at station 4 . This coincidental decrease of manganese with increased sulfide concentrations in active scep regions suggests precipitation of reduced manganesc with sulfide to form insoluble manganese sulfides. 

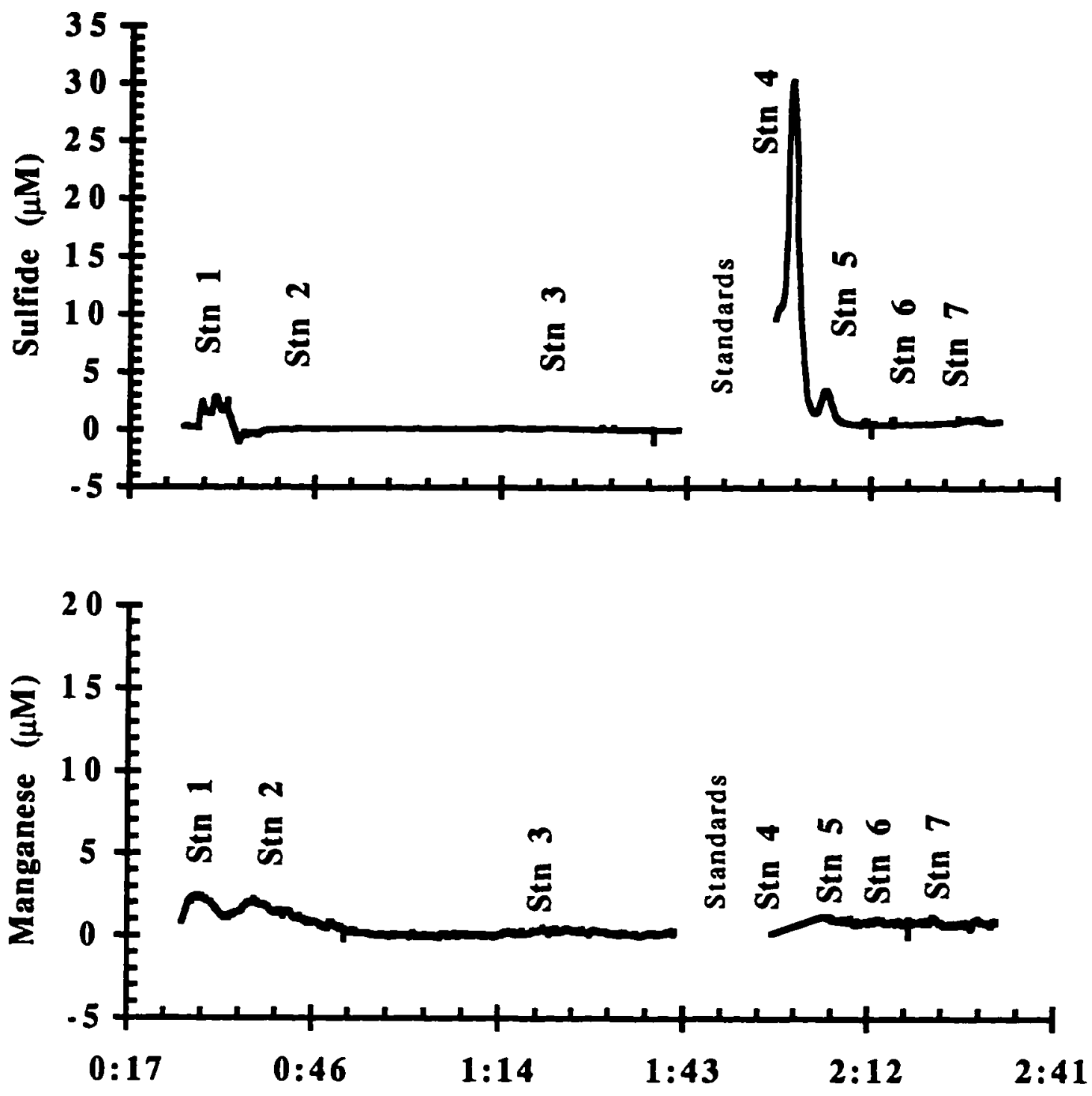

Figure 27. Timeline graph of sulfide and manganese concentrations from MBARI Ventana dive 787 at Mount Crushmore on August 12, 1994. Stn 1: Collecting clams, Stn 2: Collecting clams, Stn 3: $10-15 \mathrm{~cm}$ from live clam site, Stn 4: Live clam site, Stn 5: Brown sediments littered with disarticulated shells, Stn 6: Dark sediments without clams, Stn 7: Edge of live clam site. 
Dive 790, using the 6 channel SUAVE analyzer, yielded 6 samples (Figure 28; Appendix A-8a and A-8b). A single sample was collected within the central area of a live clam patch above the siphons in the water column (station 6) and yielded concentrations slightly clevated from background levels at $0.5 \mu \mathrm{M}$ sulfide, $0.4 \mu \mathrm{M}$ manganese, and $0.9 \mu \mathrm{M}$ silicate. The iron at station 6 was recorded as $-3 \mu \mathrm{M}$, and should be considered 0 . The negative number is a function of the standard deviation and corrections made for instrument drift when concentrations were calculated. Station 3 was taken $10 \mathrm{~cm}$ from a live clam patch and iron concentration was approximately $29 \mu \mathrm{M}$ but all other measured analytes were at background levels $\left(\mathrm{S}^{2-}=0.03 \mu \mathrm{M}, \mathrm{Mn}^{2+}=0.4 \mu \mathrm{M}\right.$, and Si $=-0.9 \mu \mathrm{M})$. The highest concentration of iron, $59 \mu \mathrm{M}$, was recorded at station 1 in the central region of orange bacterial mat. Sulfide, manganese, and silicate at this station were at background levels at $0.1,0.3$, and $0.3 \mu \mathrm{M}$ respectively. Station 2 was sampled in a general seep region with occasional live clams and was charactcrized by brownish-green sediment. This station yielded a slighlly clevated iron concentration, $22 \mu \mathrm{M}$, and silicate concentration. $3.1 \mu \mathrm{M}$. Sulfide and manganese remained at background levels at $0.2 \mu \mathrm{M}$ cach, at station 2. Stations 4 and 5 were taken in series. The sample probe was laid at the inner edge of a crack in the canyon wall surrounded by bacterial mat for the station 4 reading and for station 5 the probe was inserted deeper into the same crack. Station 4, the crack edge yielded background levels of sulfide, mangancsc, and silicate with a slightly elevated iron concentration of approximatcly $10 \mu \mathrm{M}$. Station 5 , deeper in the same crevasse, yielded the highest concentrations of sulfide $(22 \mu \mathrm{M})$, manganese $(2.4 \mu \mathrm{M})$, and silicatc $(46 \mu \mathrm{M})$ for this dive. The iron concentration $(21 \mu \mathrm{M})$ for station 5 was similar to the concentration found at the general seep site, station 2 . 

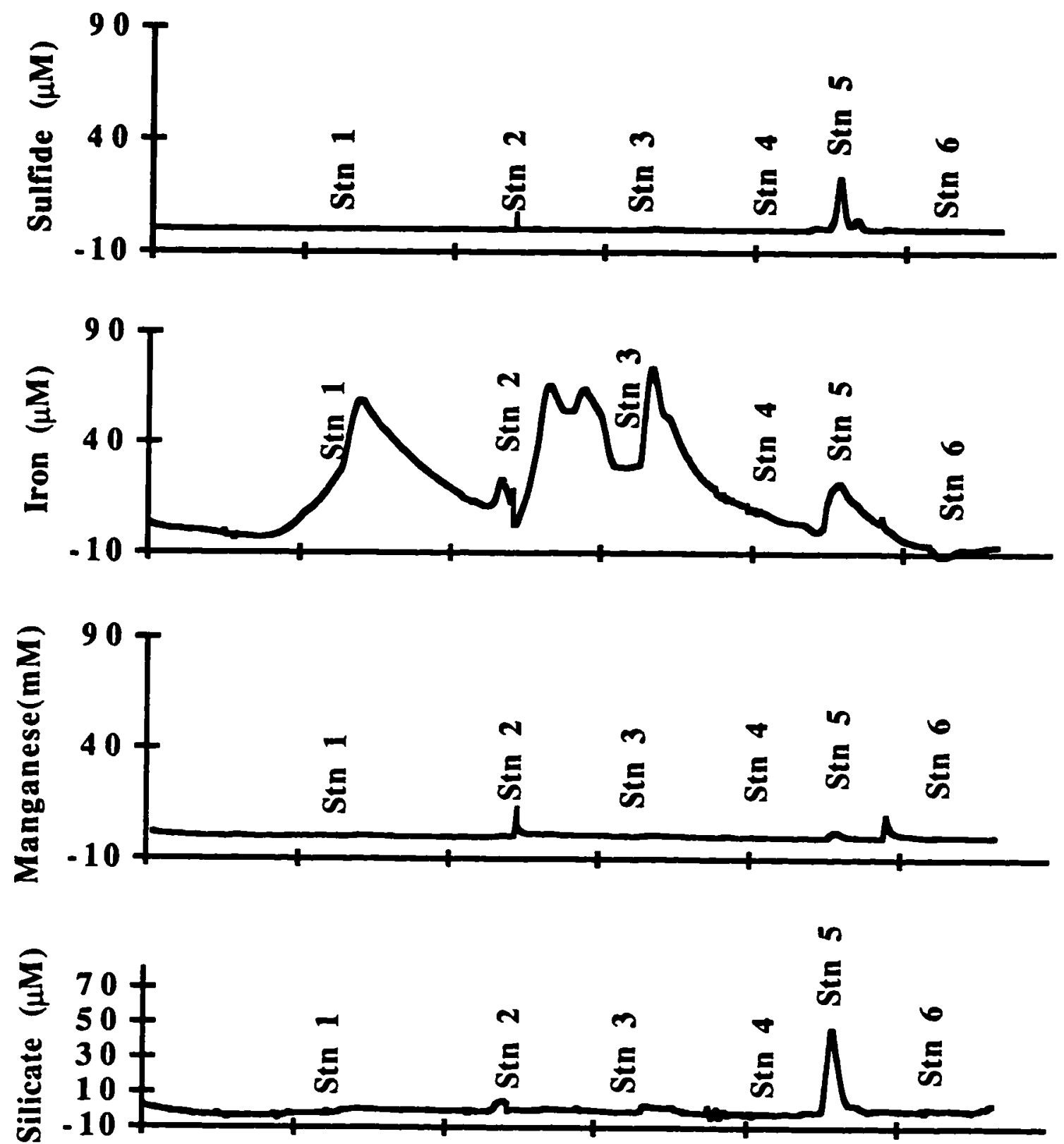

Time

Figure 28. Timeline graph of sulfide, iron, manganese, and silicate for MBARI Ventana dive 790 at Mount Crushmore, on August 18, 1994. Stn 1: Central region of orange bacterial mat, Stn 2: At marker 1 - general seep sites with widely dispersed live clams, Stn 3: $10 \mathrm{~cm}$ from edge of live clams, $S t n$ 4: Inserted into crack surrounded by bacterial mat, $S$ tn 5: Inserted deeper into the crack at Sin 4, Stn 6: Above live clams. 
Sulfide, iron, and manganese concentrations plolled versus silicate concentrations (Figure 29) showed distinct curves for all plots. Sulfide versus silicate (Figure 29a) yiclded a downward concave curve suggesting that sulfide is consumed at this site. Iron versus silicate (Figure 29b) yielded two approximately straight curves. One curve showed a narrow range of iron. 10 to $20 \mu \mathrm{M}$, to a wide range of silicate, 0 to $50 \mu \mathrm{M}$. The second curve showed a narrow range of silicate, -5 to $5 \mu \mathrm{M}$, to a wide range of iron, 0 to $75 \mu \mathrm{M}$. These two separate and distinct curves suggest two non-mixing fluid sources. The same pattern was repeated in the manganese versus silicate graph (Figure 29c). A narrow range of manganese, 0 to $2 \mu \mathrm{M}$. was found associaled with a wide range of silicate, 0 to $50 \mu \mathrm{M}$. The second curve showed a narrow range of silicate, -5 to $5 \mu \mathrm{M}$, associated with a wide range of manganese, 0 to $10 \mu \mathrm{M}$. Looking back at the sulfide graph (Figure 29a) it was possible correlate between the two sulfide points, at approximately 3 and $7 \mu \mathrm{M}$ and 0 silicate, with the straight curves found on the iron and manganese graphs (Figures 29b and 29c).

\section{Overview}

Inside active seep regions of Mount Crushmore (Tables 13 and 14) the $S^{2}$ concentrations ranged from 0 to a maximum level of $30.9 \mu \mathrm{M}$. Central regions of bacterial mat or gencral secp areas, with scattered live clams, showed lower sulfide levels of 0.1 to $1.3 \mu \mathrm{M}$ than arcas of live clams (23 and $31 \mu \mathrm{M} \mathrm{S}^{2-}$ ). Silicate concentrations, inside secps, ranged from below detection limit to 45.7 $\mu \mathrm{M}$. Thus with a calculatcd background concentration of $80 \pm 10 \mu \mathrm{M}$ (Table 6), the total maximum silicate concentration was approximatcly $126 \mu \mathrm{M}$. Concentrations of reduced iron, inside active seeps, ranged from 0.1 to $30.9 \mu \mathrm{M}$. Mangancse concentrations, inside sceps, were moderate with a maximum of 


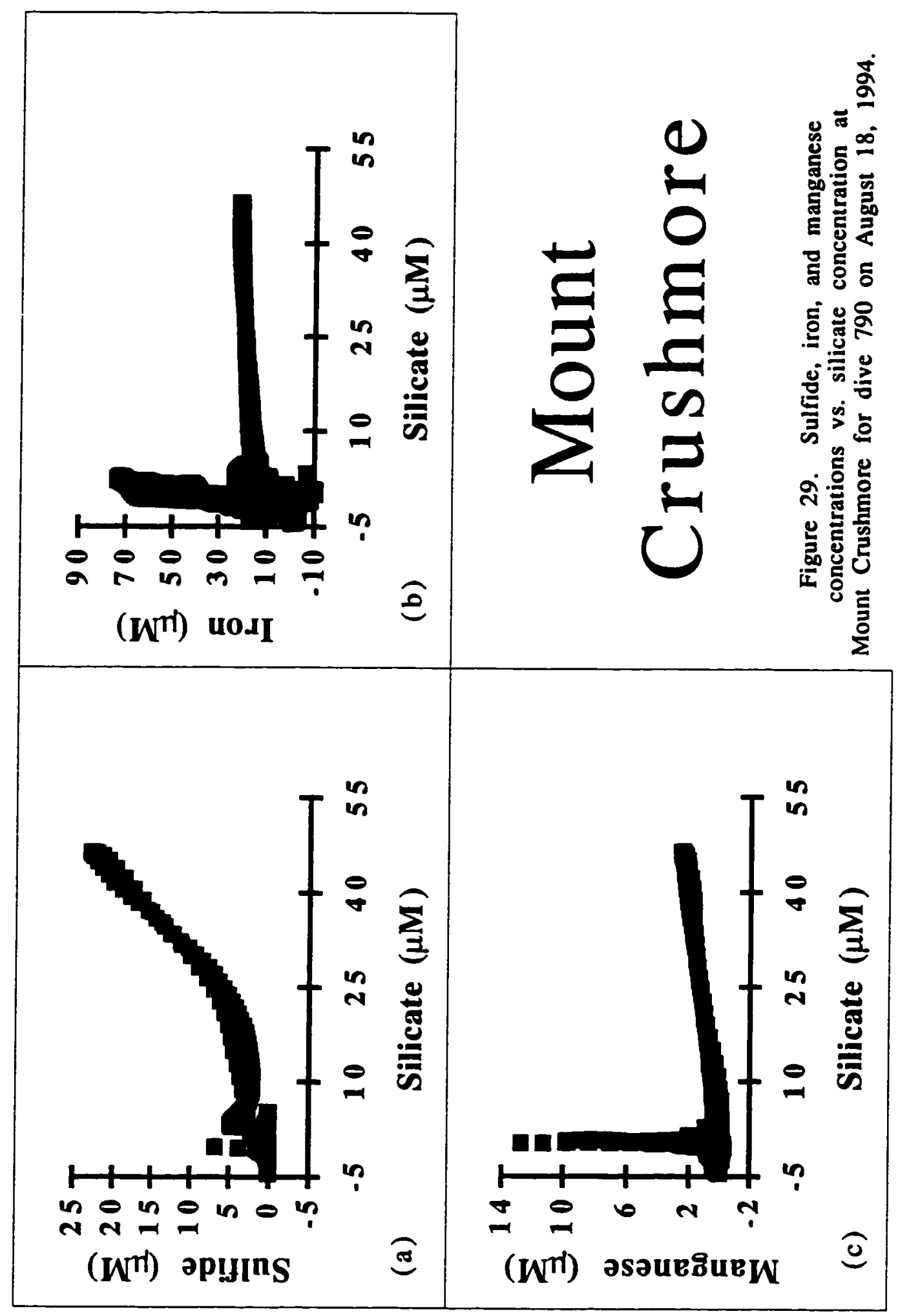


$2.5 \mu \mathrm{M}$. The highest manganese level was associated with bacterial mat not a live clam site. Iron values ranged from about $21 \mu \mathrm{M}$ to $59 \mu \mathrm{M}$. Manganese concentrations ranged from $0.3 \mu \mathrm{M}$, equivalent to outside seep values, to $2.4 \mu \mathrm{M}$. Inside seep concentrations averaged $18=7.9 \mu \mathrm{M} \mathrm{S}^{2}-, 40 \pm 26.5 \mathrm{Fe}^{2+}, 1.3 \pm 1.5 \mu \mathrm{M}$ $\mathrm{Mn}^{2+}$, and $23 \pm 32 \mu \mathrm{MSi}$ for Mount Crushmore (Table 13 and Table 14).

Outside active seep regions, concentrations of sulfide, manganese, and silicate averaged background levels $\left(0.21 \pm 0.09 \mu \mathrm{M} \mathrm{S}^{2-}, 0.47 \pm 0.2 \mu \mathrm{M} \mathrm{Mn}^{2+}\right.$, and -0.9 silicate), and well below inside active secp averages (Table 14). Iron in the single outside secp measurement was about $28 \mu \mathrm{M}$, above the background readings of 0 . but below the average inside secp concentration of $40=26.5 \mu \mathrm{M}$.

Table 13. Concentrations of sulfide, iron, manganese, and silicate determined at Mount Crushmore. Station 1 and 2 from dive 787 was removed from averages because they were taken with brief contact with sediment. "-" implies no data.

\begin{tabular}{|c|c|c|c|c|c|c|}
\hline Location & $\begin{array}{l}S^{2-} \\
\mu \mathrm{M}\end{array}$ & $\begin{array}{c}\mathrm{Fe} 2+ \\
\mu \mathrm{M}\end{array}$ & $\begin{array}{c}\mathrm{Mn}^{2}+ \\
\mu \mathrm{M}\end{array}$ & $\begin{array}{c}\mathrm{Si} \\
\mu \mathrm{M}\end{array}$ & $\begin{array}{l}\text { Station } \\
\text { Id }\end{array}$ & $\begin{array}{c}\text { Dive } \\
\text { Number }\end{array}$ \\
\hline 1. Above & 0.6 & -3.4 & 1.4 & 0.1 & 6 & 790 \\
\hline 2. Outside & 0.03 & 28.8 & 0.4 & -0.9 & 3 & 790 \\
\hline 3. Outside & 0.4 & - & $\underline{0.1}$ & - & 3 & 787 \\
\hline 4. Outside & 0.2 & - & 0.9 & - & 6 & 787 \\
\hline 5. Edgc & 0.2 & 22.5 & 0.2 & 3.1 & 2 & 790 \\
\hline 6. Edge & 0.1 & 9.8 & 0.004 & -2.2 & 4 & 790 \\
\hline 7. Edge & 4.4 & - & 1.2 & - & 5 & 787 \\
\hline 8. Edge & 0.2 & - & 0.6 & - & 7 & 787 \\
\hline 9. Inside & 22.1 & $\underline{21.3}$ & 2.4 & +5.7 & 5 & 790 \\
\hline 10. Inside & 0.1 & 58.8 & $\underline{0.3}$ & $\underline{0.3}$ & 1 & 790 \\
\hline 11. Inside & 30.9 & - & - & - & 4 & 787 \\
\hline Avg. inside & $17.7 \pm 7.9$ & $40 \pm 26.5$ & $1.35 \pm 1.5$ & $23 \pm 32$ & - & - \\
\hline & $\mathrm{n}=3$ & $n=2$ & $\mathrm{n}=2$ & $\mathrm{n}=2$ & - & - \\
\hline Avg. outside & $0.21 \pm 0.09$ & 28.8 & $0.47 \pm 0.2$ & -0.9 & - & - \\
\hline & $\mathrm{n}=3$ & $\mathrm{n}=1$ & $n=3$ & $n=1$ & - & - \\
\hline
\end{tabular}


Table 14. Mount Crushmorc minimum and maximum concentrations of the reduced ions $\mathrm{S}^{2-} . \mathrm{Fe}^{2+}, \mathrm{Mn}^{2+}$, and silicate for inside and outside active secp sites. All concentrations are reported in micro-molar units. The highest levels of iron is at a crack in the canyon wall with a red/orange discoloration without clams. The discoloration suggests secpage of high iron fluids and the lack of chemosynthetic clams or bacterial mat suggest the lack of sulfide indicating secpage of fresh aquifer waters. "-" implies no data.

\begin{tabular}{cccccccc}
\hline Ion & \multicolumn{4}{c}{ Inside Secp $-\mu \mathrm{M}$} & \multicolumn{3}{c}{ Outside Scep $-\mu M$} \\
& Min. & Max. & Avg. & Min. & Max. & Avg. \\
& & & & & & & \\
\hline $\mathrm{S}^{2}-$ & 0.1 & 31 & $17.7 \pm 7.9$ & 0.03 & 0.4 & $0.2 \pm 0.1$ \\
$\mathrm{Fc}^{2+}$ & 21.3 & 58.8 & $40 \pm 26.5$ & 28 & - & - \\
$\mathrm{Mn}^{2}+$ & 0.3 & 2.5 & $1.35 \pm 1.5$ & 0.1 & 0.9 & $0.5 \pm 0.2$ \\
$\mathrm{Si}^{2}$ & 0 & 46 & $23 \pm 32$ & -0.9 & - & - \\
Total Si & 80 & 126 & $103 \pm 32$ & 79 & - & $80 \pm 10$ \\
\hline
\end{tabular}

\section{FAULTED WALL}

Southwest of Mount Crushmore, in 1390 meters of water, the Faulted Wall site (Figure 17) is located at $36^{\circ} 44^{\prime} 49^{\prime \prime} \mathrm{N}, 122^{\circ} 00^{\prime} 15^{\prime \prime} \mathrm{W}$. Faulted Wall is a narrow active channel of the Monterey Canyon with small secp regions indicated by orange/red discolored sediments associated with cracks in the rock of the canyon wall or fissures in sediment. The biological community consists of scattered fish and an occasional crab. Faulted Wall is located east of the Palo Colorado-San Gregorio fault zone and west of the Monterey Canyon which isolates geological formations in the north from their counterparts in the south. Exposed rocks at Faulted Wall consist of granitc, possibly of the Salinian block.

\section{Scanner Data}

Faulted Wall was visited once during dive 792 on August 22, 1994 (Appendix A-9). 
Dive 792: The SUAVE analyzer was used during dive 792 at the Faulted Wall site and yiclded a total of two stations with no live clam sites tested (Figure 30). The silicate chemical channel was not working during this dive. Station 1 was sampled approximately $15 \mathrm{~cm}$ from a fracture in the canyon wall. Sulfide and manganese levels werc bclow detection limits whilc iron was high, $320 \mu \mathrm{M}$, at station 1. Station 2 was sampled in a crack surrounded by sediment that were discolored red/orange. Iron concentrations were, again, high at approximatcly $340 \mu \mathrm{M}$. Sulfide concentration remained below the detection limit and mangancse was slightly clevated from station 1 at $2.5 \mu \mathrm{M}$.

\section{Overview}

Unfortunately only 2 stations were sampled at the Faulted Wall site. Both inside and outside stations exhibited similar iron concentrations at 320 and $337 \mu \mathrm{M}$, averaging $328 \pm 12(\mathrm{n}=2)$. Sulfide concentrations were at background levels both inside and outside secps. Manganese was the only ion that showed a difference between inside, $2.5 \mu \mathrm{M}$, and outside, $0.4 \mu \mathrm{M}$ (Table 15).

Table 15. Concentrations of sulfide, iron, mangancse, and silicatc detcrmined at Faulted Wall. "-" implies no data

\begin{tabular}{lcccccc}
\hline Location & $\begin{array}{c}\mathrm{S}^{2-} \\
\mu \mathrm{M}\end{array}$ & $\begin{array}{c}\mathrm{Fc}^{2+} \\
\mu \mathrm{M}\end{array}$ & $\begin{array}{c}\mathrm{Mn}{ }^{2+} \\
\mu \mathrm{M}\end{array}$ & $\begin{array}{c}\mathrm{Si} \\
\mu \mathrm{M}\end{array}$ & $\begin{array}{c}\text { Station } \\
\text { Id }\end{array}$ & $\begin{array}{c}\text { Dive } \\
\text { Number }\end{array}$ \\
\hline Outsidc & 0.6 & 320 & 0.4 & - & 1 & 792 \\
Inside & 0.2 & 337 & 2.5 & - & 2 & 792 \\
\hline
\end{tabular}



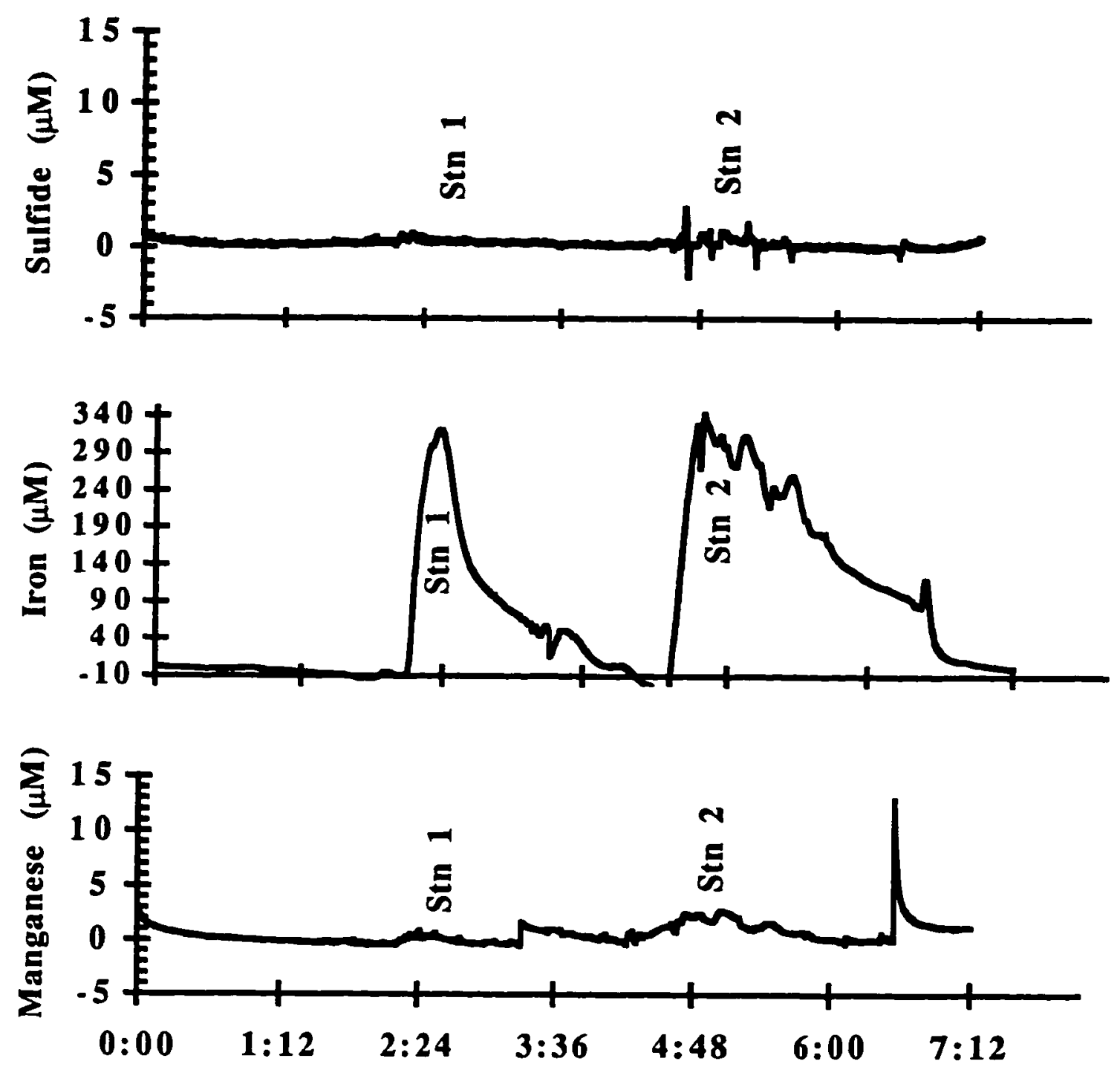

Figure 30. Timeline graph of sulfide, iron, and manganese for MBARIVentana dive 792 at Faulted Wall on August 22, 1994. Stn 1: $15 \mathrm{~cm}$ from fracture in canyon wall, Stn 2: At crack in canyon wall with orange-red discoloration. 


\section{DISCUSSION}

The 4 cold secp sites studied in the Monterey Bay region show distinct variations in the concentrations of the measured analytes sulfide, iron. manganese, and silicate (Figure 31 and 32). Sulfide showed the greatest variation between sites (Figure 31a), iron had two sites with similar concentrations (Figures $31 \mathrm{~b}$ ), manganese had three sites with similar concentrations (Figure $3 \mathrm{lc}$ ), and silicate had a single high reading with readings at two additional sites similar (Figure $31 \mathrm{~d}$ ).

\section{STATISTICAL ANALYSIS}

\section{Inside vs. Outside}

First, the difference between ion concentrations found inside and outside active seep regions at each sitc is discussed. Statistical analysis was performed using Microsoft EXCEL 5.0 standard students t-test, assuming equal variance at the $95 \%$ confidence level. Concentration values were converted to $\log (1+$ ion concentration), to mitigate large variation in concentration measurements, before statistical analysis. $P$ values for one-tail analysis were reported.

Clam Field had significant differences between inside and outside active seep region concentrations for all ions (Table 16; Figure 33a). Sulfide, iron. and silicate had $P$ values of $1.3 \times 10^{-6}, 0.08$, and $2.0 \times 10^{-4}$. well below the probability that the concentrations were similar outside and inside active secp regions (Appendix B-2, B-4, and B-8). A single outside seep region measurement was recorded for iron at Clam Ficld. The t-lest showed a significant difference between inside and outside concentrations of iron, however, a single measurement cannot be verified as representative of outside iron con- 


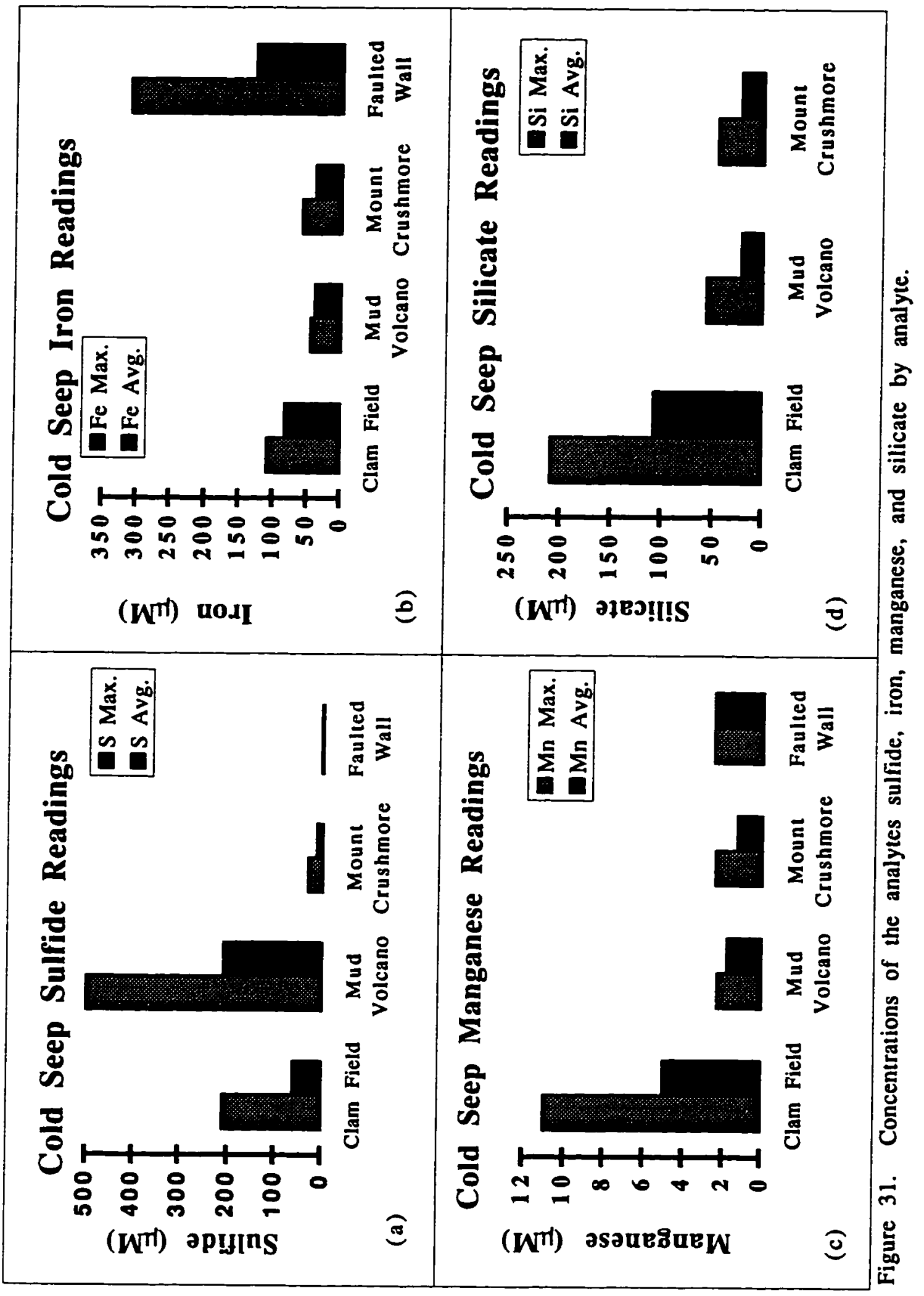




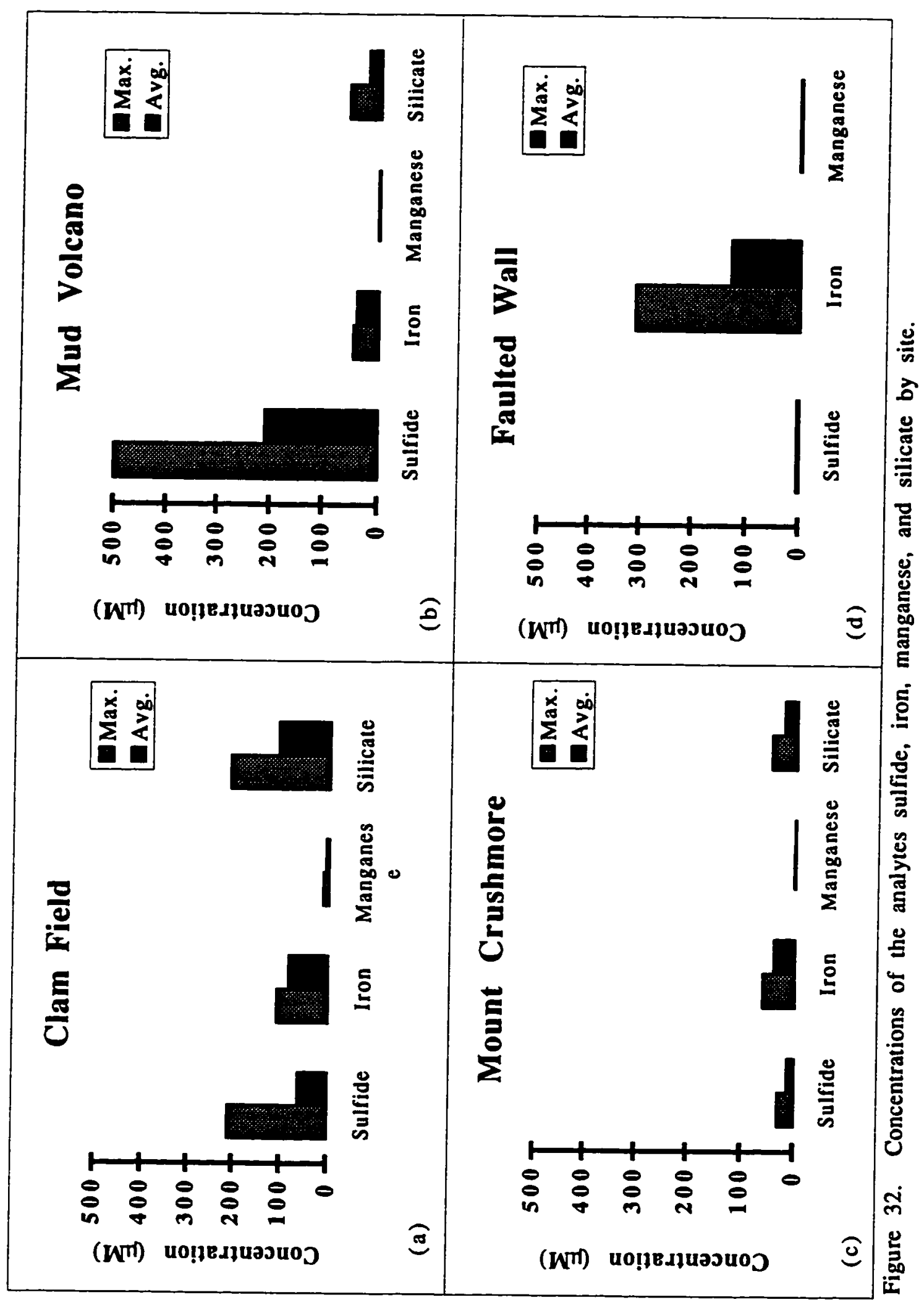




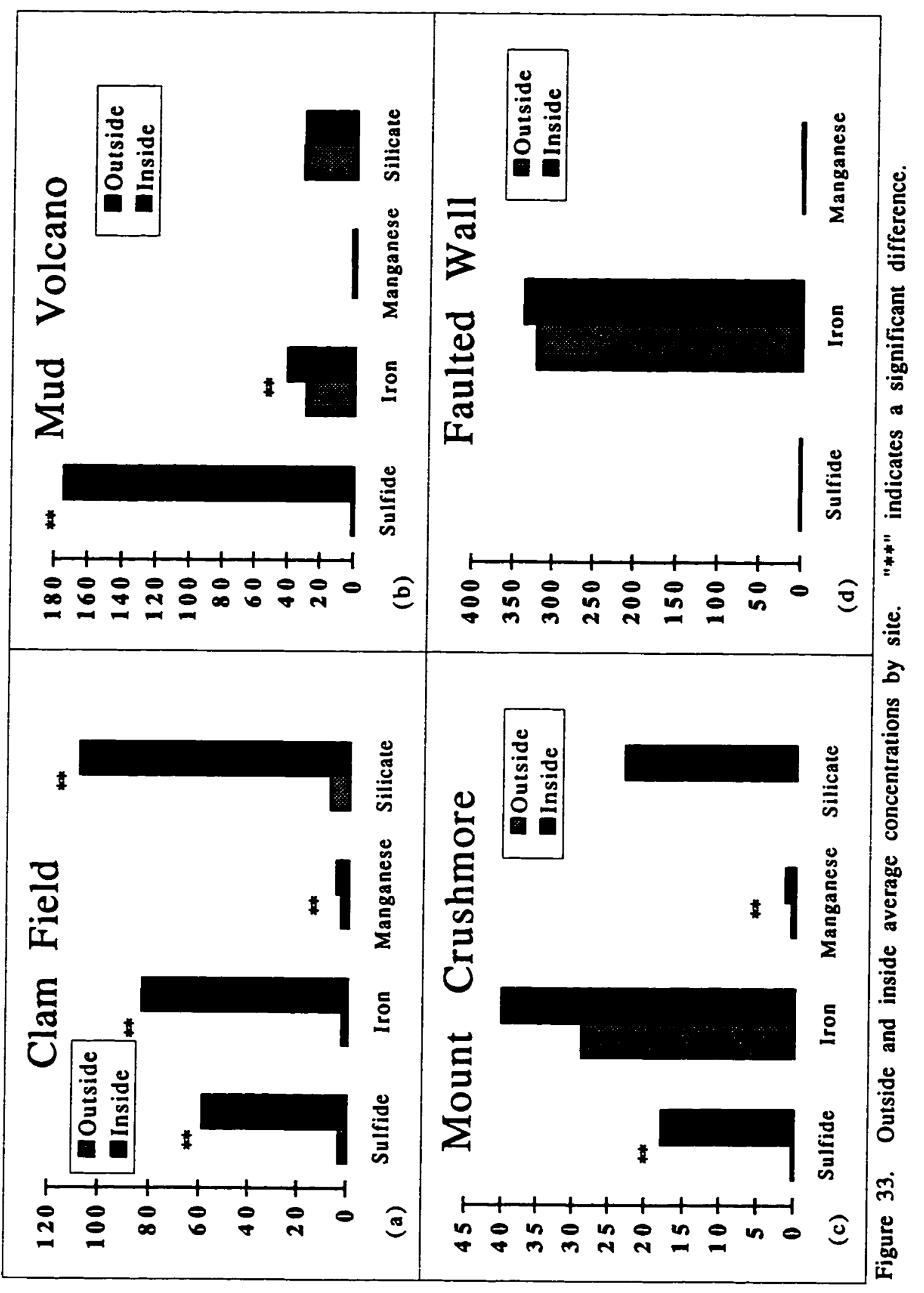


centration values. The probability that manganese values were similar inside and outside seeps is below the $10 \%$ level, with $\mathrm{P}=0.09$ (Appendix B-6).

Mud Volcano showed a significant difference in outside versus inside concentrations for sulfide with a $P$ value of 0.013 (Appendix B-10). The measured iron concentrations for inside and outside active seep regions had a $\mathrm{P}=0.16$ (Appendix B-12). However, only 4 total measurements (2 inside and 2 outside) were taken at Mud Volcano for iron. A more significant difference may be found by future studies. The sample size for manganese and silicate ( $\mathrm{n}=2$ and $\mathrm{n}=3$ ) was also small. The t-test for $\mathrm{Mn}^{2+}$ and $\mathrm{Si}$ concentrations showed no evidence that the concentrations varied between inside and outside seep regions with $P=0.36$ and 0.45 (Appendix B-14 and B-16). Mud Volcano showed a significant difference between outside and inside concentrations for sulfide, a probable difference for iron, and no difference for manganese and silicate (Table 16; Figure 33 b).

Mount Crushmore showed a significant difference in sulfide concentrations inside and outside seeps with $\mathrm{P}=0.065$ (Appendix B-18). Iron and silicate concentrations showed no significant difference between inside and outside locations ( $P=0.39$ and 0.33; Appendix B-20 and B-24). Manganese had a $20 \%$ probability of having similar concentrations inside and outside seeps (Appendix B-22). The total sample size for all ions at Mount Crushmore was again small $\left(\mathrm{S}^{2-}: 3\right.$ outside, 3 inside; $\mathrm{Fe}^{2+}: 1$ outside, 2 inside; $\mathrm{Mn}^{2+}: 3$ outside, 2 inside; $\mathrm{Si}$ : 1 outside, 2 inside). Thus a more definite pattern may emerge with further investigation. In conclusion, Mount Crushmore showed a significant difference of inside versus outside concentrations for sulfide, a possible difference for manganese, and no difference for iron and silicate (Table 16; Figure 33c). 
Table 16. Overview of statistical analysis of inside vs. outside concentrations of $\mathrm{S}^{2-}, \mathrm{Fe}^{2+}, \mathrm{Mn}^{2+}$, and $\mathrm{Si}$. "**" indicates a significant difference, "-" indicates no significant difference, and $" * "$ indicates the $P$ value ranged from 0.10 to 0.20 .

Insufficient data (Insuf. Data) was available for analysis of Faulted Wall.

\begin{tabular}{|c|c|c|c|c|}
\hline Site & $\begin{array}{c}S^{2-} \\
\text { In vs. Out }\end{array}$ & $\begin{array}{c}\mathrm{Fe}^{2+} \\
\text { In vs. Out }\end{array}$ & $\begin{array}{c}\mathrm{Mn}^{2+} \\
\text { In vs. Out }\end{array}$ & $\begin{array}{c}\text { Si } \\
\text { In vs. Out }\end{array}$ \\
\hline $\begin{array}{l}\text { Clam Field } \\
\text { Mud Volcano } \\
\text { Mount Crushmore } \\
\text { Faulted Wall }\end{array}$ & $\begin{array}{c}* * \\
* * \\
* * \\
\text { Insuf. Data }\end{array}$ & $\begin{array}{c}* * \\
* \\
\text { Insuf. Data }\end{array}$ & $\begin{array}{c}* * \\
- \\
* \\
\text { Insuf. Data }\end{array}$ & $\begin{array}{c}* * \\
- \\
- \\
\text { Insuf. Data }\end{array}$ \\
\hline
\end{tabular}

Statistical tests were not performed using Faulted Wall data because only a single measurement, inside and outside active seep regions, was taken.

The sites at Clam Field, Mud Volcano, and Mount Crushmore are clearly influenced by large changes in the chemistry of the sediment pore waters. The significant differences found between chemical concentrations at stations within the seep sites and the outside sites are testimony to this. The focus of this discussion now shifts to examining differences between sites to see if detectable differences can be used to fingerprint the fluid sources.

Site vs. Site

The significance of the difference of sulfide, iron, manganese, and silicate concentrations between sites was tested using a two-tailed t-test assuming equal variances. Concentrations were again transformed to $\log (1+$ concentration) before testing. Test results, $P$ values and size of samples, were collated into Table C-1 found in Appendix C.

Maximum sulfide concentrations varied widely among sites except between Mount Crushmore and Faulted Wall (Figure 31a). However, a significant difference for sulfide was found only between the Clam Field site and the sites 
Mount Crushmore and Faulted Wall $(P=0.15$ and 0.02$)$. There was a marginal significant difference for sulfide between Mud Volcano and Faulted Wall $(P=$ 0.21). Clam Field and Mud Volcano showed no significant difference for sulfide measured inside active seep regions $(P=0.97$, although the sulfide average for the two sites varied widely at $58.7 \pm 4 \mu \mathrm{M}$ and $174 \pm 84 \mu \mathrm{M}$. The discrepancy was possibly associated with the small sample size and large range of sulfide concentrations found at Mud Volcano. Additionally, a significant difference was not found between Mud Volcano and Mount Crushmore, $P=0.41$, and Mount Crushmore and Faulted Wall, $\mathrm{P}=0.44$.

Iron showed a difference between most sites that was significant (Figure 31b; Appendix C-1). The Clam Field site was significantly different, for iron concentrations, from Mud Volcano, Mount Crushmore, and Faulted Wall ( $\mathrm{P}=$ $0.10,0.18$, and 0.08). Mud Volcano and Faulted Wall differed significantly with approximately $8 \%$ chance of having similar values. Mount Crushmore and Faulted Wall showed a questionable significant difference with $P=0.24$. The small sample size for Mount Crushmore and Faulted Wall ( $n=2$ and 1) possibly affected the validity of this test. The notable exception to significant variation between sites is Mud Volcano and Mount Crushmore which were definitely not significantly different $(P=0.85)$. This similarity of concentrations between Mud Volcano and Mount Crushmore was also found in their iron average values of $40 \pm 9 \mu \mathrm{M}$ and $40 \pm 26 \mu \mathrm{M}$. However, only 2 measurement for iron were taken at each site and iron concentrations varied widely at Mount Crushmore (21 and $59 \mu \mathrm{M})$ as indicated by the large standard error of 26 .

Manganese, on the other hand, showed few significant differences between sites (Appendix C-1). The average concentrations between sites showed similar results with the obvious anomalous reading associated with 
Clam Field (Figure 31c). Clam Field showed a significant difference between Mount Crushmore $(P=0.21)$. No significant difference was found between Mud Volcano and any other site (Clam Field - $P=0.38$; Mount Crushmore - $P=0.65$; and Faulted Wall, $P=0.58$ ). Mount Crushmore and Faulted Wall also did not show a significant difference in manganese concentrations with a $P=0.65$.

Silicate concentrations varied significantly between Clam Field and the sites Mud Volcano and Mount Crushmore $(P=0.01$ and 0.02). Mud Volcano silicate concentrations of active seep regions were not significantly different from measurements at Mount Crushmore $(P=0.91)$. The average silicate concentrations $(108 \pm 6 \mu \mathrm{M}$ at Clam Field, $30.6 \pm 15 \mu \mathrm{M}$ at Mud Volcano, $23 \mu \mathrm{M}$ at Mount Crushmore) showed the same trend (Figure 31d). Silicate measurements were not available from Faulted Wall, therefore comparison with other sites was not performed.

\section{RELATIVE CONCENTRATIONS}

The average sulfide concentrations (Figure 31a; Tables 10, 12, 14, and 15) were at a maximum, $174 \pm 84 \mu \mathrm{M}$, at the Mud Volcano. The Clam Field site had an intermediate sulfide concentration with an average of $59 \pm 4 \mu \mathrm{M}$. A significant difference was not found between Mud Volcano and Clam Field sulfide concentrations when tested (Appendix C-1). However, the maximum values between these sites differed dramatically $(>500 \mu \mathrm{M}$ at Mud Volcano and $208 \mu \mathrm{M}$ at Clam Field), and relative concentration values were assigned based on average values. The lowest values of sulfide were found at Mount Crushmore (avg. $=18 \pm 8 \mu \mathrm{M}$ ) and Faulted Wall. Sulfide levels at Faulted Wall were below the detection limit of the instrument. In summary, the relative sulfide concentrations for these sites are: 


\section{Mud Volcano - highest; \\ Clam Field - intermediate; \\ Mount Crushmore - lowest; and \\ Faulted Wall - lowest.}

Iron concentrations (Figure 31b; Tables 10,12, 14, and 15) were maximal at Faulted Wall in a region of orange bacterial mat with no visible evidence of clams with a value of $308 \mu \mathrm{M}$. The next highest level of iron, $83 \pm 13 \mu \mathrm{M}$ was recorded at the Clam Field site. The lowest concentrations of iron were found at Mud Volcano and Mount Crushmore, with average values of $40 \pm 9 \mu \mathrm{M}$ and $40 \pm 26 \mu \mathrm{M}$. All relationships of iron concentrations between sites show a significant difference (Appendix C-1), except Mud Volcano and Mount Crushmore. Mud Volcano and Mount Crushmore obviously had similar iron concentration averages (Figure $31 \mathrm{~b}$ ). In summary, the relative iron concentrations for the studied are:

$$
\begin{aligned}
& \text { Faulted Wall - highest; } \\
& \text { Clam Field - intermediate; } \\
& \text { Mud Volcano - lowest and } \\
& \text { Mount Crushmore - lowest. }
\end{aligned}
$$

Manganese concentrations (Figure 31c; Tables 10,12, 14, and 15) did not reveal a pattern. The only relationship of manganese between sites that showed a significant difference was Clam Field and Mount Crushmore (Appendix C-1). However, the average value of manganese at Clam Field, $5 \pm 0.4 \mu \mathrm{M}$, was well above the average manganese concentrations at other sites. Similar concentrations of manganese were found at Mount Crushmore, $1.4 \pm 1.5 \mu \mathrm{M}$, and Mud Volcano, $1.8 \pm 0.7 \mu \mathrm{M}$, with slightly higher values at Faulted Wall, $2.5 \mu \mathrm{M}$. Clam Field, has the highest recorded value for manganese at an average value of approximately $5 \pm 0.39 \mu \mathrm{M}$. The relative manganese concentrations for the studied sites are: 
Clam Field - highest;

Mud Volcano - lowest;

Mount Crushmore - lowest; and

Faulted Wall - lowest/intermediate.

Silicate concentrations (Figure 31d; Tables 10, 12, 14, and 15) were only determined at Clam Field, Mud Volcano, and Mount Crushmore and showed a declining average concentration for those sites in that order. Clam Field had the highest recorded silicate concentration averaging value of $108 \pm 6 \mu \mathrm{M}$. Mud Volcano and Mount Crushmore average silicate concentrations were equivalent at $22 \pm 15 \mu \mathrm{M}$ and $23 \pm 32 \mu \mathrm{M}$ above ambient sea water levels. Statistical tests showed a significant difference between Clam Field and the sites Mud Volcano and Mount Crushmore. A significant difference was not found between Mud Volcano and Mount Crushmore for silicate concentrations. The relative silicate concentrations for the studied sites are:

Clam Field - highest;

Mud Volcano - lowest/intermediate; and

Mount Crushmore - lowest/intermediate.

The relative concentrations of ions found at active seep sites were collated into Table 17 and compared with the expected relative ion concentration for fluid expulsion methods listed in Table 3 found in the Introduction. Sulfide had the most varied concentrations and suggested the association of the site with the source/expulsion/migration method.

\section{Mud Volcano}

Mud Volcano correlated closely with the expected relative concentrations of a hydrocarbon generation site with the highest concentration of sulfide and the lowest level of iron (Table 17 and Table 3 ). The expected level of silicate at a hydrocarbon generation site were intermediate, while the level 
Table 17. Relative ion concentration for sulfide, reduced iron, reduced manganese, and silicate found at active seep sites.

\begin{tabular}{ccccc}
\hline $\begin{array}{c}\text { Expulsion } \\
\text { Method }\end{array}$ & $\mathrm{S}^{2-}$ & $\mathrm{Fe}^{2+}$ & $\mathrm{Mn}^{2+}$ & $\mathrm{Si}$ \\
\hline $\begin{array}{c}\text { Clam Field } \\
\text { Mud Volcano }\end{array}$ & Highest & Lowest & Lowest & $\begin{array}{c}\text { Howest - } \\
\text { Intermediate } \\
\text { Mount Crushmore }\end{array}$ \\
Faulted Wall & Lowest & Highest & $\begin{array}{c}\text { Highest - } \\
\text { Lowest } \\
\text { Intermediate }\end{array}$ & $\begin{array}{r}\text { Insuf. data } \\
\text { Intermediate }\end{array}$ \\
\hline
\end{tabular}

found was lowest/intermediate. The level of $\mathrm{Mn}^{2+}$ found was among the lowest of measured sites while the expected relative concentration was slightly higher with a lowest/intermediate classification. This high sulfide reading suggests that this site is the most likely, of the 4 , to be dominated by fluid flow driven by hydrocarbon generation. Other investigators provided supporting evidence that the site is involved with the generation of hydrocarbons. High (310 $\mu \mathrm{M})$ methane concentrations with a thermogenic methane isotopic signature in interstitial fluids have been observed (Barry et al., submitted a; Martin et al., submitted). The total silicate concentration was below the expected concentration of 300 to $500 \mu \mathrm{M}$ (Introduction, p. 32) at about $142 \pm 15$ $\mu M$ (Table 12). This suggests that the fluids that were sampled were diluted with ambient seawater. Assuming the ambient seawater concentrations of silicate is $120 \mu \mathrm{M}$ and the undiluted porewater silicate is $500 \mu \mathrm{M}$, the samples analyzed averaged $70 \%$ seawater and $30 \%$ porewater. 
Tectonic compression may be active and a source of overpressuring of the region at this time (Barry et al., submitted a), although Stakes et al. (submitted) indicated that the area is not located "directly on major faults". The initial fluid source remains hydrocarbon based fluids of the Monterey Formation even if the overpressuring of the region is currently controlled by tectonic compression. Interstitial fluids escaped along areas of fractured rock as indicated by the small aggregations of live clams and the low levels of sulfide found in the immediate vicinity of active seeps.

Clam Field

Clam Field appeared to be correlated with a tectonically compressed site with intermediate levels of sulfide (Table 17 and Table 3 ). Iron, manganese, and silicate levels were higher than expected, with intermediate iron concentrations and the highest manganese and silicate concentrations. The total silicate concentration averaged $218 \pm 10 \mu \mathrm{M}$ which was below the expected silicate concentration expected (Introduction, p. 31 ).

Sea water trapped in sediment above the Monterey Formation is likely the primary fluid source that provided intermediate levels of sulfide. Tectonic compression, associated with the active faults of the Monterey Bay fault zone, provided overpressure required for seep generation.

An alternative sulfide source was speculated to be derived from a hydrocarbon source associated with the shale of the Monterey Formation (Barry et al., submitted a). Stakes et al. (submitted) reported that the $\delta^{13} \mathrm{C}$ isotope composition of carbonates indicated methane generated from either thermogenic or biogenic sources supporting a mixed source hypothesis. However, many carbonate samples also indicated exclusive biotic methane generation and the methane concentrations of porewater in the region were 
low at approximately $10.6 \mu \mathrm{M}$ (Barry et al., submitted a) indicating a minimal hydrocarbon source. A hydrocarbon generation source of sulfide from the Monterey Formation may have played a role of seep generation at $\mathrm{Clam}$ Field in the past but it appears to be insignificant in the present time as evidenced by low $\mathrm{S}^{2-}$. It is therefore speculated that sea water trapped in sediment is the primary source of initial seep fluids and tectonic compression dominated at the Clam Field site.

\section{Mount Crushmore}

Among the lowest sulfide and highest silicate concentrations were found at Mount Crushmore and indicate an aquifer forced environment. The iron and manganese concentrations at Mount Crushmore, however, were among the lowest measurements (Figure 31). It was conjectured that iron concentrations, at aquifer based sites, would be high due initial high concentrations in aquifer based waters and the absence of sulfide to form FeS precipitates (Introduction, p. 15). Manganese, also, was expected to be high at aquifer sites due to the high concentration found in aquifer waters (2 mM; Muir, 1977, 1982).

However, Mount Crushmore exhibited two distinct source fluids (Figure 29). Low iron and manganese levels may have been associated with buried sea water which contain lower initial concentrations of iron and manganese. Aquifer based water, from the Purisima Formation, appeared to be funneled into small regions indicated by tightly clustered, deeply buried, clams. White and orange bacterial mat were biological indicators of high $\mathrm{Fe}^{2+}$ and $\mathrm{Mn}^{2+}$, even though high concentrations were not recorded.

The fluid flow is thought to be initiated by artesian conditions within the Purisima Formation (Greene, 1990; Orange et al., submitted b; Sullivan, 1994). Stakes et al. (submitted) reported high values of $\delta^{13} \mathrm{C}$ in tested siltstones 
indicating association with the Monterey Formation and high temperature diagenesis. However, Barry et al. (submitted a) found levels of methane to be undetectable suggesting that there is a lack of hydrocarbon genesis at this site at present time. Tectonic action is active in the region with the Soquel Canyon resting within the Monterey fault zone (Greene, 1990; Sullivan, 1994). Supporting the hypothesis that two processes function at Mount Crushmore and include aquifer forcing and tectonic compression.

\section{Faulted Wall}

Faulted Wall correlated closely with the expected relative ion concentration of an aquifer forced site. Faulted wall had the lowest level of sulfide, $0.2 \mu \mathrm{M}$, measured at any tested site. The highest iron concentrations, approximately $300 \mu \mathrm{M}$, were also recorded at Faulted Wall. The relative manganese concentration was lower than expected classified as lowest/intermediate, rather than highest. Similar concentrations of manganese were found at Mount Crushmore, the other possible aquifer forced site. Unfortunately no silicate data was available for this site.

Similar to Mount Crushmore, fluid flow of Faulted Wall is thought to be associated with artesian conditions of the Purisima Formation. The site, also located within the Monterey Fault zone, may have had tectonic compression element associated with fluid flow.

\section{Overview}

The relative ion concentrations found at active seep regions (Table 17) within the Monterey Bay region showed distinct correlation's between expected relative ion concentration conjectured for the specified source/expulsion/migration mechanisms (Table 3). However, the complex geological nature of the Monterey Bay region precludes a single fluid 
expulsion process functioning within a cold seep region. Tectonic compaction, sediment exposure, and overburden compaction are concurrently present at many, if not all, cold seep sites within the Monterey Bay region. In addition, the water bearing Purisima Formation and hydrocarbon Monterey Formation underlies much of the Monterey Bay region, making aquifer forcing and hydrocarbon expansion possible expulsion methods among many cold seeps of the region.

\section{FLUID CHANNELING}

Cold seep fluids are channeled through fractures in substrate to form pools of high concentrations of reduced ions at focal points indicated by increased concentrations of sulfide, reduced iron, reduced manganese, and/or silicate in surficial sediment or fissures found in canyon walls or rocky outcrops (Photographs 3 and 4). Visible cues to increased concentrations of reduced ions are typically associated with changes in sediment color or communities of chemosynthetic organisms. Dark sediment, gray to black, indicate sulfide precipitates suggesting areas of slightly elevated sulfide ranging to $10 \mu \mathrm{M}$ (Stn. 8, dive 698, Clam Field). Calyptogena sp. clams indicate higher concentrations of sulfide. The specific species may be indicative to the relative amount of sulfide at a site. Barry et al. (submitted a) reported that the clam Calyptogena pacifica was dominate species at Mount Crushmore where low sulfide concentrations were recorded while Calyptogena kilmeri was the dominant species at Mud Volcano and Clam Field where higher concentrations of sulfide were recorded (Figure $31 \mathrm{a}$ ).

The chemical gradients across these indicators of cold seep regions can be quite dramatic (Figure 34). A gradient of sulfide was found that increased 

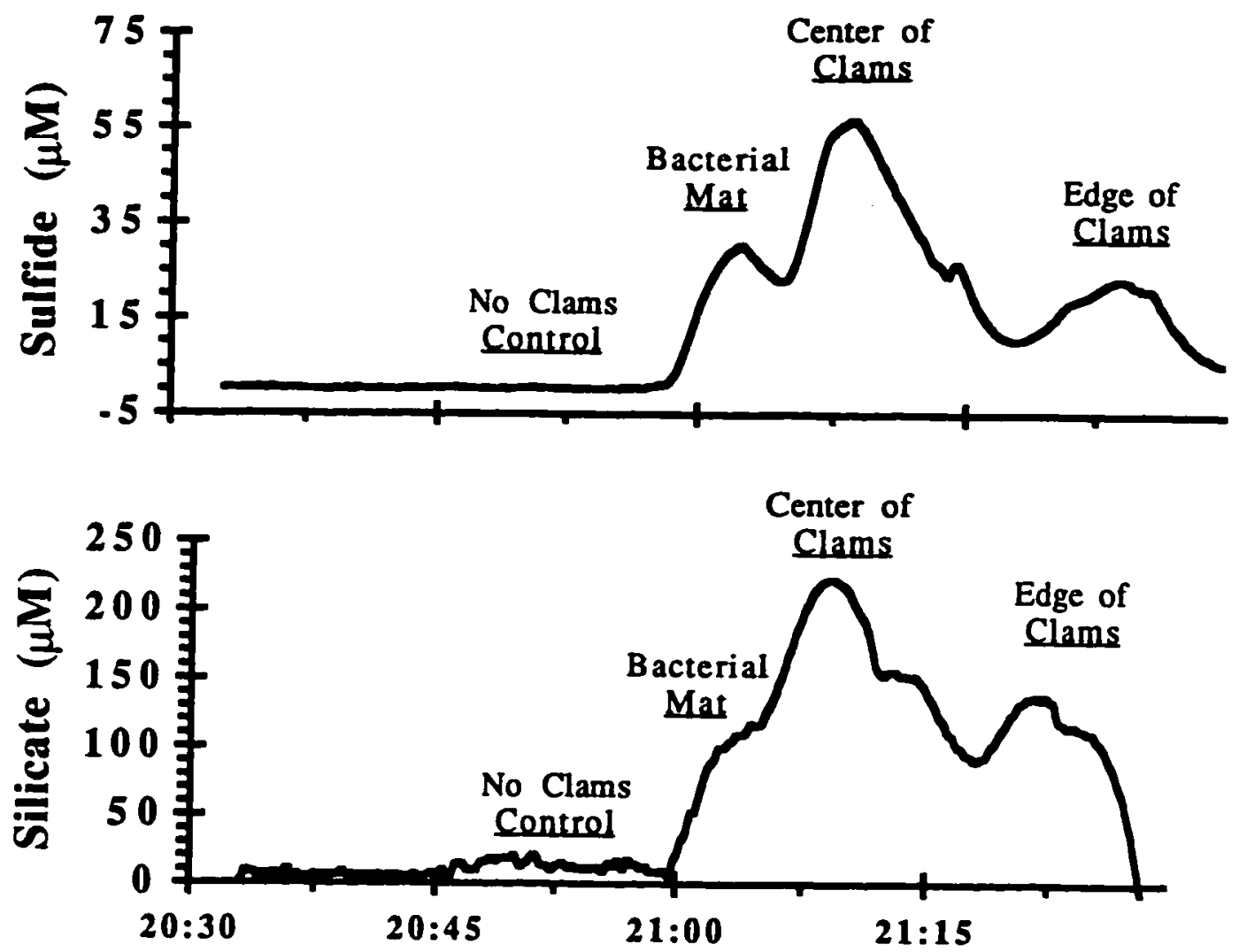

Figure 34. Sulfide and silicate concentrations increase as readings are taken from outside seep regions, indicated by brown sediments, at the edge of a live clam patch, in the central region of live clams, then on the opposite edge of the live clam patch. Readings were taken during dives 796 and 797, September 6 , 1994, at Clam Field.

from an average of $0.7 \mu \mathrm{M}$ outside active seeps, $12 \mu \mathrm{M}$ at the edge of clams to a maximum of $>500 \mu \mathrm{M}$ within the central region of an active seep at the Mud Volcano site. In contrast to $\mathrm{S}^{2-}$, the average inside concentration for silicate, iron, and manganese at the Mud Volcano are only slightly higher than outside concentrations for these ions (Appendix A-8). Several measurements of column water immediately above an active seep region, identified by live clams, were taken during this study. Sulfide concentrations recorded at these 
Stations (Stn. 1 and 4, dive 698, Clam Field; Stn. 1, dive 699, Mud Volcano; Stn. 6, dive 790, Mount Crushmore) are very low ranging from $0 \mu \mathrm{M}$ to $6 \mu \mathrm{M}$. The lack of sulfide in the water column precludes establishment of Vestimentiferan tube worms at these sites. Tube worms utilize their brachial plumes, which extend well above sediment, to extract sulfide and oxygen from the water column (Fisher, 1995). Embley et al. (1990) found Polybrachia sp. at deeper sites on the Ascension Fan Valley where it is unknown if sulfide can be found in the water column. Slightly elevated concentrations of silicate, ranging from 15 to $30 \mu \mathrm{M}$, was located immediately above an active seep site at Clam Field in the water column indicating that seep fluids may escape the sediment into the water column. This suggests that sulfide oxidizes quickly to sulfate when it comes in contact with oxygenated ambient sea water.

The behavior of clams appears to vary depending upon the relative concentration of sulfide available at the site. The Mount Crushmore site has relatively low concentrations of sulfide and clams are found deeply buried in sediment pooled in crevices marked by dark sediment (Photograph 3). At sites where high concentrations of sulfide are records, such as the Mud Volcano, clams ring cells of black sediment and lay loosely in surficial sediment (Photograph 6). Calyptogena sp. at the Clam Field site known for moderate sulfide concentrations clams are found in loose groups, although they are sometimes densely packed, with about half the clam shell submerged in sediment (Photograph 5). 


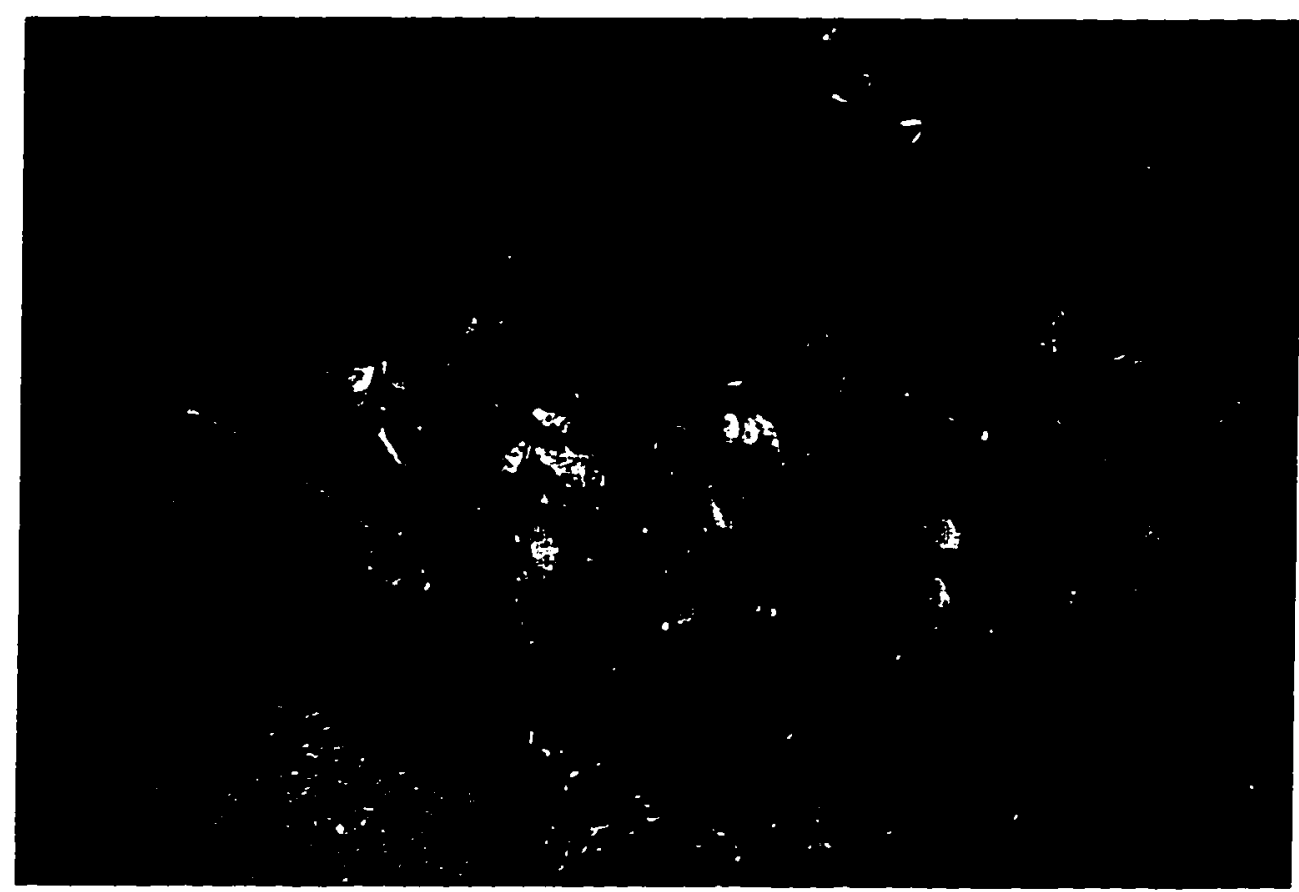

Photograph 3. Clams often congregate in cervices where sediments collect.

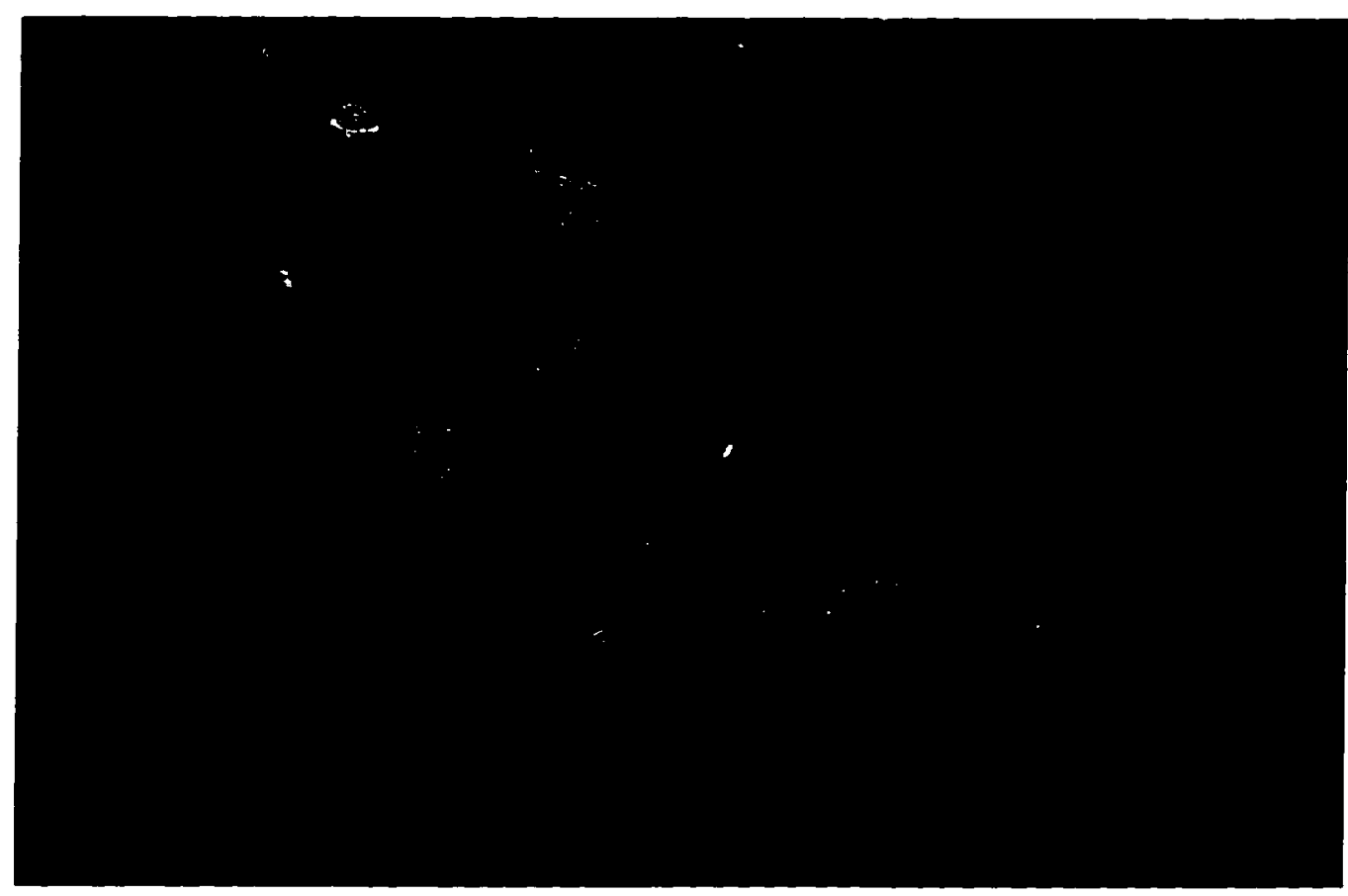

Photograph 4. Orange and white bacterial mat at Mount Crushmore. These bacterial mats are thought to utilize $\mathrm{Fe}^{2+}$ and $\mathrm{Mn}^{2+}$ 


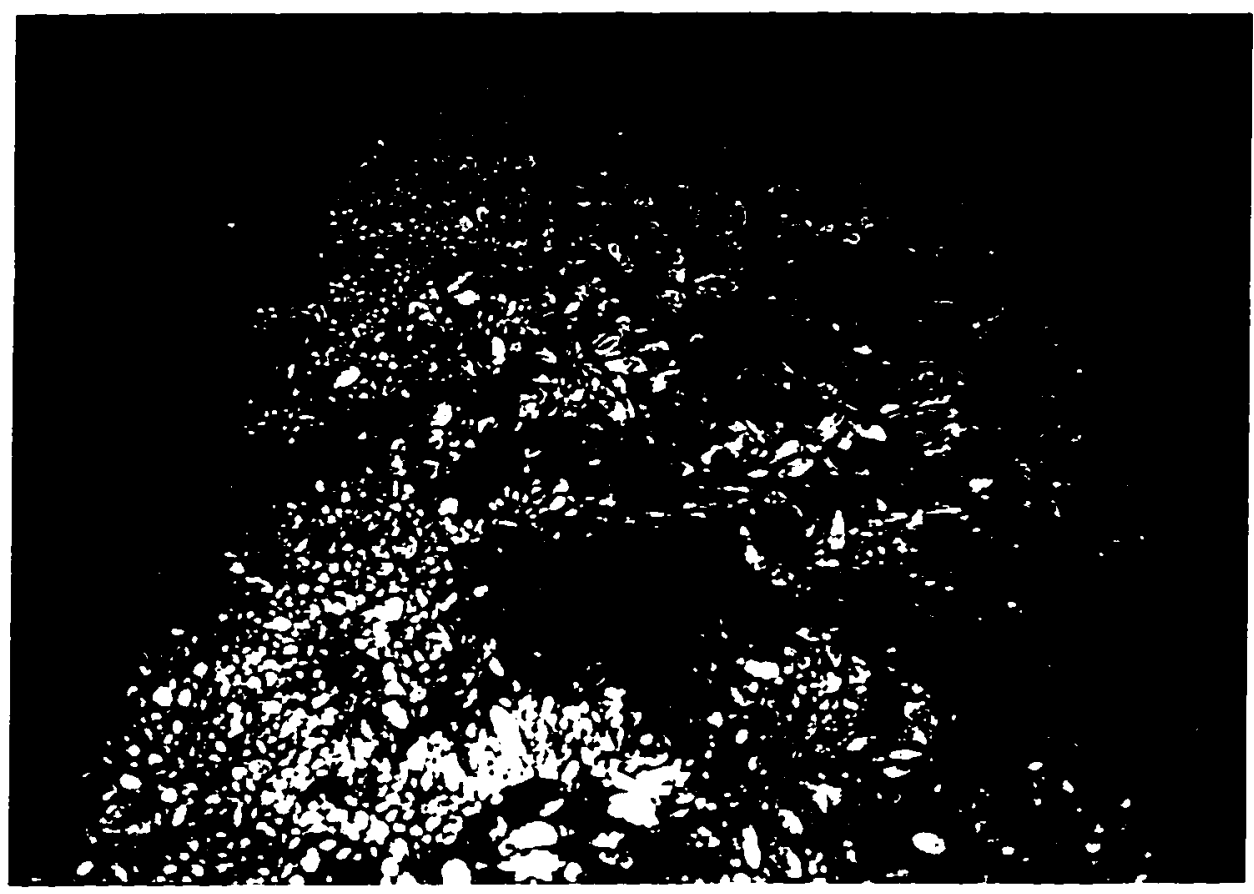

Photograph 5. Clams are distributed over a wide area at Clam Field.

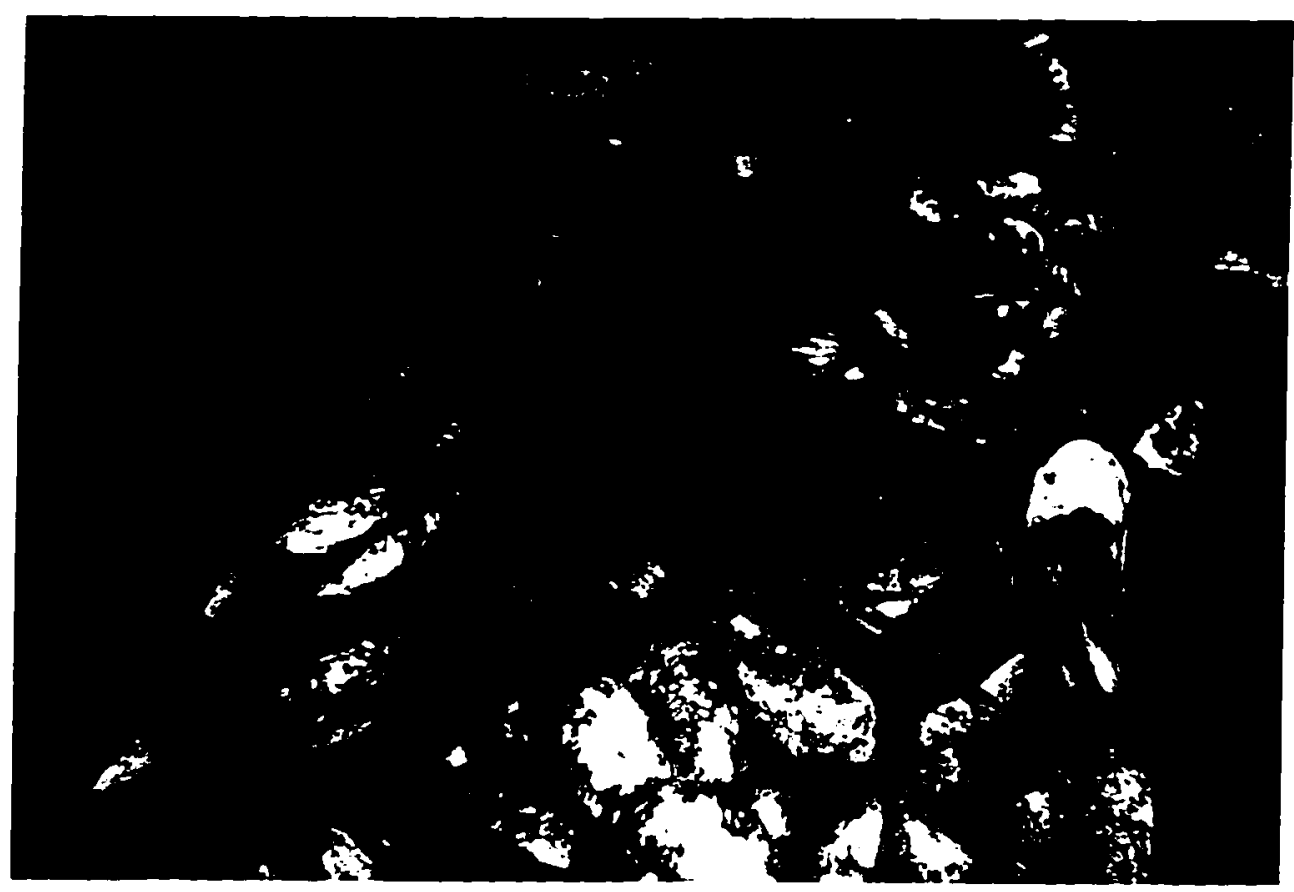

Photograph 6. Clams collect around dark patches of sediments. 


\section{CONCLUSION}

The Monterey Bay region is geologically complex providing structures and processes for a variety fluid expulsion pathways that provide reduced ions capable of supporting cold seep ecosystems. The available evidence (e. g., Barry et al., submitted a; Greene and Hicks, 1990; Greene, Orange, and Barry, 1993; Green et al., 1993; Greene et al., 1995; Martin et al., submitted; Orange et al., 1993, 1994, submitted a, b; Stakes et al., submitted) suggests that multiple fluid expulsion methods function at individual cold seep sites in the Monterey Bay region. Expulsion methods functioning in the Monterey Bay region include, among others: tectonic compaction, aquifer forcing, hydrocarbon generation, rapid exposure of deep sediments, and slumping. The predominant feature of an individual seep site is the dominant initial source fluid which provides the chemical signature and controls the reducing environment of the seep.

While a single initial source fluid may predominate a cold seep, multiple source fluids may be present, as evident at Mount Crushmore (Figure 29). These initial source fluids can remain separate (when moving through impermeable conduits), or mix (when moving through diffuse and permeable sediments).

The relative concentrations (Table 17), based on average $\mathrm{S}^{2-}, \mathrm{Fe}^{2+}, \mathrm{Mn}^{2+}$, and $\mathrm{Si}$ concentrations at studicd sites, show a distinct correlation with the expected relative concentrations of source/expulsion/migration mechanisms (Table 3). The correlation of expected versus recorded relative concentrations lead to the classification of chemical "fingerprint" and source/expulsion/ migration mechanism for each site (Figure 32; Table 18). 
Table 18. Relative concentration of ions of tested sites. MV = Mud Volcano, $\mathrm{CF}=$ Clam Field, $\mathrm{MC}=$ Mount Crushmore, and FW = Faulted Wall. The High(est), Inter(mediate), and Low(est) ratings reflect the relative ion concentration for the site. Insufficient data was available for silicate concentrations for Faulted Wall.

\begin{tabular}{cccccc}
\hline Site & Method & $\mathrm{S}^{2-}$ & $\mathrm{Fe}^{2+}$ & $\mathrm{Mn}{ }^{2+}$ & $\mathrm{Si}$ \\
\hline GF & Tectonic & Inter & Inter & High & High \\
MV & Hydrocarbon & High & Low & Low & Low/Inter \\
MC & Aquifer & Low & Low & Low & Low \\
FW & Aquifer & Low & High & Low/Inter & Insuf. data \\
\hline
\end{tabular}

The reduced chemical species $\mathrm{S}^{2-}, \mathrm{Fe}^{2+}$, and $\mathrm{Mn}^{2+}$ are present to some degree in all sites studied. However, reduced chemical species found at cold seeps sites in the Monterey Bay region vary by site. The absolute concentrations of reduced ions appears to affect the species of chemosynthetic organisms found at the site as proposed by Barry, Kochevar, and Baxter (submitted b).

The seep fluid of Mud Volcano, the hydrocarbon site, is modified by deep thermogenic hydrocarbon within the Monterey Formation at depths greater than $2 \mathrm{~km}$ below the sediment surface. The expulsed fluid is anoxic, providing a highly reducing environment. Sulfide concentrations at Mud Volcano are the highest of the three sites, with concentrations reaching beyond $500 \mu \mathrm{M}$. Push core samples, reported by Barry et al. (submitted a), contained $10.3 \mathrm{mM}$ sulfide in sub-surface interstitial waters. The presence of thermogenic hydrocarbons at Mud Volcano is verified by the work of Martin et al. (submitted) and Stakes et al. (submitted). Barry et al. (submitted a) reported the highest level of methane in the region $(310 \mu \mathrm{M})$, which suggests a thermogenic rather than biogenic methane source because of the large 
concentration of methane. The bacterial mat present is grayish in coloration, and the predominant clam is Calyptogena kilmeri. Silicate concentrations range from ambient, calculated at 118 to $124 \mu \mathrm{M}$, to approximately $50 \mu \mathrm{M}$ above ambient. Manganese concentrations are moderate at about $12 \mu \mathrm{M}$, which is the lowest maximal value found between sites. Iron concentrations are low, as was expected, ranging from $2 \mu \mathrm{M}$ and about $50 \mu \mathrm{M}$. The overpressuring of the region is currently fluid expansion due to the generation hydrocarbons and tectonic compaction, possibly provided by the Palo Colorado-San Gregorio fault zone. Smooth Ridge, on which Mud Volcano is located, is a large piece of uplifted seafloor, indicating that tectonic compression plays a role in maintaining overpressure in this region. In the past, it is possible that large releases of methane gas were the primary source of overpressure, as indicated by the presence of pock marks (Vogt et al., 1994).

Clam Field, located in the Monterey Bay fault zone, has a chemical signature correlated with a predominately tectonic site (Table 17). The initial source fluid is sea water trapped in sediment as indicated by a moderate level of sulfide. Tectonic overpressure, suggested by the high angle faults in the region, forces anoxic fluids from sediment to the sediment-water interface. The faulting in the region is predominantly strike-slip in nature, providing much less compression than other types of faults, suggesting that the expulsed fluid of Clam Field originate from a much shallower source than other site types. Sulfide concentration average $59 \pm 3.8 \mu \mathrm{M}$ at Clam Ficld, while Mud Volcano sulfide average is much higher at $174 \pm 84 \mu \mathrm{M}$. Barry et al. (submitted a) report a similar trend with $10.9 \mathrm{mM}$ levels of sulfide in the interstitial waters at Clam Field, which is lower than the values they report at Mud Volcano. Iron and manganese concentrations maximize at $94 \mu \mathrm{M}$ and $36 \mu \mathrm{M}$, 
showing moderate iron and mangancse concentrations. Silicate concentrations are high, averaging $218 \pm 10 \mu \mathrm{M}$. The biological community is similar to the community found at Mud Volcano, with grayish bacterial mat and the predominant clam Calyptogena kilmeri. Barry et al. (submitted a) report low concentrations of methane $(10.6 \mu \mathrm{M})$. Stakes et al. (submitted) indicated that methane source for carbonate formation is biogenic methane, supporting the hypothesis that the initial source fluid is sea water.

The aquifer site, Mount Crushmore, utilizes ground water as the initial fluid source. There is evidence (Figure 29) of a secondary fluid source which is sea water buried during sedimentation. The Purisima Formation is well established as a water bearing structure (Greene, 1977; Greene and Hicks, 1990; Muir, 1977; Sullivan, 1994) and it is exposed in the Mount Crushmore region (Barry, submitted a; Greene, 1977; Sullivan, 1994). Overpressure is provided by the head gradient of the source aquifer, which forces fresh ground water though the highly fractured Purisima Formation. The visible characteristics of the seep site are dramatically different from the Mud Volcano and Clam Field sites. Orange and whitc bacterial mats, indicative of iron and manganese utilizing bacteria, are present. The predominant clam is Calyptogena pacifica, instead of $C$. kilmeri found at the Mud Volcano and Clam Field sites. Sulfide concentrations are low, with a maximum level of $30.9 \mu \mathrm{M}$ recorded, and total silicate concentration is high, averaging $203 \pm 32 \mu \mathrm{M}$, supporting the aquifer based hypothesis. However, iron and manganese levels are unexpectedly low, averaging $40 \pm 26 \mu \mathrm{M}$ and $1.35 \pm 1.5 \mu \mathrm{M}$, suggesting a sccondary source. Mount Crushmore shows two distinctive source components which are unmixed (Figure 29). This can be explained by one member associated with fresh water channeled though fractures and impermeable conduits of the Purisima 
Formation, and a secondary sea water source driven by tectonic compression. Mixing of the two sources is prohibited if sufficient fluid flow flushes the secondary source from sediment or impermeable conduits continue close to the surface. The concept of impermeable conduits funneling aquifer waters and second unmixed fluid source, support the hypothesis that there are multiple overpressure processes functioning in the Monterey Bay region. Sulfide shows a distinctively graphed concave curve which, compared to the conservative ion silicate, indicates the utilization of sulfide by chemosynthetic organisms or oxidation to sulfate at the sediment-water interface.

Faulted Wall, the second aquifer site, unfortunately has little available data. The single active seep region sample shows a distinctive fresh water signature with extremely low sulfide $0.2 \mu \mathrm{M}$. Iron and manganese concentrations are high at $340 \mu \mathrm{M}$ and $2.5 \mu \mathrm{M}$ and are consistent with high mincral content of ground water of the Salinas Valley (Muir, 1977). Faulted Wall is located within the southern Monterey Bay and exposed rock appears to be granite. Fluid is possibly ground water seepage from an unidentified groundwater subbasin (Figure 8). The limited data set prohibits speculation on additional source fluids or expulsion methods.

The four sites studied showed distinctive chemical fingerprints for the geological process and predominant initial source fluid implicated at each cold seep site. The relative concentrations of the ions $\mathrm{S}^{2-}, \mathrm{Fe}^{2+}, \mathrm{Mn}^{2+}$, and $\mathrm{Si}$ effect the composition of the biological communities at cold seep sites within the Monterey Bay region. Overpressures driving cold seep sites of Monterey Bay are determined by multiple gcological processes, which can be differentiated based on their fluid compositions. 


\section{LITERATURE CITED}

Atwater, T. 1970. Implications of Plate Tectonics for the Cenozoic Tectonic Evolution of Western North America. Geolegical Society of America Bulletin 81: 3513-3536.

Ayers, W., and others. 1994. Water Resources Data: Califomia Water Year 1994. Vol. 2. Pacific Slope Basins From Arroyo Grande to Oregon State Line Except Central Valley. USGS Water-Data Report CA-94-2, Sacramento, CA: U.S. Geological Survey.

Barker, C. 1972. Aquathermal Pressuring - Role of Temperature in Development of Abnormal-Pressure Zones. The American Association of Petroleum Geologists Bulletin 56(10): 2068-2071.

Barry, J. P., H. G. Greene, D. L. Orange, C. H. Baxter, B. H. Robison, R. E. Kochevar, J. W. Nybakken, D. L. Reed, and C. M. McHugh. Submitted a. Biologic and Geologic Characteristics of Cold Seeps in Monterey Bay. California. Deep-Sea Research.

Barry, J. P., R. E. Kochevar, and C. H. Baxter. Submitted b. The Influence of Pore-Water Chemistry and Physiology in the Distribution of Vesicomyid Clams at Cold Seeps in Monterey Bay: Implications for Patterns of Chemosynthetic Community Organization. Limnology and Oceanography.

Bauer, J. E., P. A. Montagna, R. B. Spies, M. C. Prieto, and D. Hardin. 1988. Microbial biogeochemistry and heterotrophy in sediments of a marine hydrocarbon seep. Limnology and Oceanography 33(6, part 2): 14931513.

Berelson, W. M., D. E. Hammond, and K. S. Johnson. 1987. Benthic fluxes and cycling of biogenic silica and carbon in two southern California borderland basins. Geochimica et Cosmochimica Acta 5: 1345-1363.

Berelson, W. M., D. E. Hammond, D. O'Neill, X-M. Xu, C. Chin, and J. Zukin. 1990. Benthic fluxes and pore water studies from sediments of the central equatorial north Pacific: Nutrient diagenesis. Geochimica et Cosmochimica Acta 54: 3001-3012.

Betteridge, D., Q. Fernando, and H. Freiser. 1963. Solvent Extraction of Certain Transition Metal Ions with 1-(2-Pyridylazo)-2-naphthol: A Study of Complex Formation and Distribution Equilibria. Analytical Chemistry 35(3): 294-298.

Boulègue, J., J. T. Iiyama, J. Charlou, and J. Jedwab. 1987. Nankai Trough, Japan Trench and Kuril Trench: geochemistry of Fluids sampled by submersible "Nautile." Earth and Planetary Science Letters 83: 363-375. 
Bowen, R. 1986. Groundwater, 2nd cd. New York: Elsevier Applied Science Publishers, New York.

Brooks, J. M., M. C. Kennicutt II, C. R. Fisher, S. A. Macko, K. Cole, J. J. Childress, R. R. Bidigare, and R. D. Vetter. 1987. Deep-Sea Hydrocarbon Seep Communities: Evidence for Energy and Nutritional Carbon Sources Science 238: 1138-1141.

Cadet, J. P., K. Kobayashi, S. Lallemand, L. Jolivet, J. Aubouin, J. Boulègue, J. Dubois, H. Hotta, T. Ishii, K. Konishi, N. Niitsuma, and H. Shimamura. 1987. Deep scientific dives in the Japan and Kuril Trenches. Earth and Planetary Science Letters 83: 313-328.

Cary, C., B. Fry, H. Felbeck, and R. D. Vetter. 1989. Multiple trophic resources for a chemoautotrophic community of a cold water brine seep at the base of the Florida Escarpment. Marine Biology 100(3): 411-418.

Childress, J. J., H Felbeck, and G. N. Somero. 1987. Symbiosis in the deep sea. Scientific American. 255: 114-120.

Chin, C. S. 1991. SPECTROPHOTOMETRIC DETERMINATION OF DISSOLVED MANGANESE IN NATURAL WATERS: IN SITU CHEMICAL MAPPING IN HYDROTHERMAL PLUMES, WITH CONCURRENT MEASUREMENTS OF TOTAL DISSOLVED IRON. M. S. Thesis., Moss Landing Marine Laboratories.

Chin, C. S., K. H. Coale, V. A. Elrod, K. S. Johnson, G. J. Massoth, and E. T. Baker. 1994. In situ observations of dissolved iron and manganese in hydrothermal vent plumes, Juan de Fuca Ridge. Lournal of Geophysical Research 99(B3): 4969-4984.

Claypool, G. E. and I. R. Kaplan. 1974. THE ORIGIN AND DISTRIBUTION OF METHANE IN MARINE SEDIMENTS. In Natural Gases in Marine Sediments, ed. by I. R. Kaplan, pp. 99-139. New York: Plenum Press.

Cline, J. D. 1969. Spectrophotometric Determination of Hydrogen Sulfide in Natural Waters. Limnology and Oceanography 14(3): 454-458.

Corliss, J. B., J. Dymond, L. I. Gordon, J. M. Edmond, R. P. von Herzen, R. D. Ballard, K. Green, D. Williams, A. Bainbridge, K. Crane, and T. H. van Andel. 1979. Submarine thermal springs on the Galapagos Rift. Science 203: 1073-1083.

Crouch, J. K., S. B. Bachman, and J. T. Shay. 1984. POST-MIOCENE COMPRESSIONAL TECTONICS ALONG THE CENTRAL CALIFORNIA MARGIN. In Tectonics and Sedimentation Along the California Margin: Pacific Section 38: $37-54$.

DeMaster, D. J. 1981. The supply and accumulation of silica in the marine environment. Geochimica el Cosmochimica Acta 45: 1715-1732. 
Embley, R. W., S. L. Eittreim, C. H. McHugh, W. R. Normark, G. H. Rau, B. Hecker, A. E. DeBevoise, H. G. Greene, W. B. F. Ryan, C. Harrold, and C. Baxter. 1990. Geological setting of chemosynthetic communities in the Montercy Fan Valley system. Deep-Sea Research 37(11): 1651-1667.

Emerson, S., L. Jacobs, and B. Tebo. 1983. THE BEHAVIOR OF TRACE METALS IN MARINE ANOXIC WATERS: SOLUBILITIES AT THE OXYGEN-HYDROGEN SULFIDE INTERFACE. In TRACE METALS IN SEA WATER, ed. C. S. Wong, E. Boyle, K. W. Bruland, J. D. Burton, and E. D. Goldberg, pp. 579-608. New York: Plenum Press.

Fetter, C. W. 1988. Applied Hydrogeology 2nd ed. New York: Macmillan Publishing Company.

Fiala-Médioni, A., J. Boulègue, S. Ohta, H. Felbeck, and A. Mariotti. 1993. Source of energy sustaining the Calyptogena populations from deep trenches in subduction zones off Japan. Deep-Sea Research 40(6): 1241-1258.

Fisher, C. R. 1995. Toward an Appreciation of Hydrothermal-Vent animals: Their Environment, Physiological Ecology, and Tissue Stable Isotope Values. In Seafloor Hydrothermal Systems: Physical, Chemical. Biological. and Geological Interactions, ed. S. E. Humphris,

R. A. Zierenberg, L. S. Mullineaux, and R. E. Thomson, pp. 297-316. Washington, DC: American Geophysical Union.

Fonselius, S. H. 1983. Determination of hydrogen sulphide. In Methods of Seawater Analysis, 2nd. Revised and Extended Edition, ed. K. Grasshoff, M. Ehrhardt, and K. Kremling, pp. 73-80. Deerfield Beach, Florida: Verlag Chemie.

Froelich, P. N., G. P. Klinkhammer, M. L. Bender, N. A. Luedtke, G. R. Heath, D. Cullen, P. Dauphin, D. Hammond, B. Hartman, and V. Maynard. 1979. Early oxidation of organic matter in pelagic sediments of the eastern equatorial Atlantic: suboxic diagenesis. Geochimica et Cosmochimica Acta 43: $1075-1090$.

Goff, J. C. 1983. Carbon generation and migration from Jurassic source rocks in the $E$ Shetland Basin and Viking Graben of the northern North Sea. Loumal of the Geological Society 140: 445-474.

Grasshoff, K. M. and K. M. Chan. 1971. An automatic method for the determination of hydrogen sulfide in natural waters. Analytica Chimica Acta 53: $442-445$.

Greene, H. G. 1970. GEOLOGY OF SOUTHERN MONTEREY BAY AND ITS RELATIONSHIP TO THE GROUND WATER BASIN AND SALT WATER INTRUSION, United States Department of the Interior, Geological Survey, Open-file report. 
1977. GEOLOGY OF THE MONTEREY BAY REGION, Open-file Report 77 -

718, United States Department of the Interior.

1990. Regional tectonics and structural evolution of the Monterey Bay region, central California. In: Geology and tectonics of the central California coastal region. San Francisco to Monterey ed. R. E. Garrison, H. G. Greene, K. R. Hicks, G. E. Weber, T. L. Wright, pp. 31-56. Pacific section of the AAPG Guidebook.

Greene, H. G., and K. R. Hicks. 1990. Ascension-Monterey Canyon System: History and Development. In Geology and tectonics of the Central California coastal region. San Francisce to Monterey, ed. R. E. Garrison, H. G. Greene, K. R. Hicks, G. E. Weber, and T. L. Wright. Camarillo, CA: American Association of Petroleum Geologists, Pacific Section.

Greene, H. G., D. Orange, and J. Barry. 1993. Geological Diversity of Cold Seep Communities, Monterey Bay Region, Central California, U.S.A. EOS Transactions. American Geophysical Union 74(43): 578.

Greene, H. G, D. S. Stakes, D. L. Orange, J. P. Barry, and B. H. Robison. 1993. APPLICATION OF A REMOTELY OPERATED VEHICLE IN GEOLOGIC MAPPING OF MONTEREY BAY, CALIFORNIA, USA. Proceedings: American Academy of Underwater Sciences Thirteenth Annual Scientific Diving Symposium, September 19-22, 1993. 430 Nahant Road, Nahant, MA 01908.

Greene, H. G, M. M. Yoklavich, D. Sullivan, and G. M. Cailliet. 1995. A GEOPHYSICAL APPROACH TO CLASSIFYING MARINE BENTHIC HABITATS: MONTEREY BAY AS A MODEL. WORKSHOP PROCEEDINGS: APPLICATIONS OF SIDE-SCAN SONAR AND LASER-LINE SYSTEMS IN FISHERIES RESEARCH January 20. 1994. Alaska Dept. of Fish and Game, Special Publications No. 9.

Greenberg, A. E., L. S. Clesceri, and A. D. Eaton, ed. 1992. STANDARD METHODS: For the Examination of Water and Waste Water, 18th ed. American Public Health Association, 1015 Fifteenth Strect, NW, Washington DC 20005.

Hashimito, J., S. Ohta, T. Tanaka, H. Hotta, S. Matsuzawa, and H. Sakai. 1989. Deep-sea communities dominated by the giant clam, Calyptogena soyoe, along the slope foot of Hatsushima Island, Sagami Bay, Central Japan. Paleogeography. Paleoclimatology. Paleoecology 71: 179-192.

Hecker, B. 1985. Fauna from a cold sulfur-seep in the Gulf of Mexico: comparison with hydrothermal vent communities and evolutionary implications. Bulletin of the Biological Society of Washington 6: 467-473.

Hedges, J. I. and R. G. Keil. 1995. Sedimentary organic matter preservation: an assessment and speculative synthesis. Marine Chemistry 49(2-3): 81-115. 
Hessler, R. R. and V. A. Kaharl. 1995. The Deep-Sea Hydrothermal Vent Community: An Overview. In Seafloor Hydrothermal Systems: Physical, Chemical. Biological, and Geological Interactions, ed. S. E. Humphris, R. A. Zierenberg, L. S. Mullineaux, and R. E. Thomson, pp. 72 - 84. Washington DC: American Geophysical Union.

Hirayama, K. and N. Unohara. 1988. Spectrophotometric Catalytic Determination of an Ultratrace Amount of Iron(III) in Water Based on the Oxidation of N,N-Dimethyl-p-phenylenediamine by Hydrogen Peroxide. Analytical Chemistry 60(23): 2573-2577.

Humphris, S. E., R. A. Zierenberg, L. S. Muilineaux, and R. E. Thomson, ed. 1995. Seafleor Hydrothermal Systems: Physical, Chemical. Biological, and Geological Interactions. Washington, DC: American Geophysical Union.

Jannasch, H. W. 1983. Microbial processes at deep-sea hydrothermal vents. In Hydrothermal Processes at Sea Floor Spreading Centers, ed. P. A. Rona, K. Boström, L. Laubier, and K. L. Smith, pp. 677-709. New York: Plenum Press.

1989. Litho-autotrophically sustained ecosystems in the deep sea. In Biology of Autotrophic Bacteria, ed. H. G. Schlegel and B. Bowien, pp. 147166. Madison, WI: Science Technology Publications.

1995. Microbial Interactions With Hydrothermal Fluids. In Seafleer Hydrothermal Systems: Physical. Chemical. Biological. and Geological Interactions, ed. S. E. Humphris, R. A. Zierenberg, L. S. Mullineaux, and R. E. Thomson, pp. 273 - 296. Washington, DC: American Geophysical Union.

Johnson, K. S., C. L. Beehler, and C. M. Sakamoto-Amold. 1986. A SUBMERSIBLE FLOW ANALYSIS SYSTEM. Analytica Chimica Acta 179: 245-257.

Jollivet, D., J. Faugeres, R. Griboulard, D. Desbruyeres, and G. Blanc. 1990. Composition and spatial organization of a cold seep community on the South Barbados accretionary prism: tectonic, geochemical and sedimentary context. Progress in Oceanography 24(1/4): 25-45.

Juniper, S. K. and M. Sibuet. 1987. Cold seep benthic communities in Japan subduction zones: spatial organization, trophic strategies and evidence for temporal evolution. Marine Ecology - Progress Series 40: 115-126.

Kelley, J. T., S. M. Dickson, D. F. Belknap, W. A. Bamhardt, and M. Henderson. 1994. Giant sea-bed pockmarks: Evidence for gas escape from Belfast Bay, Maine. Geology 22(January): 59-62.

Kennicutt II, M. C., J. M. Brooks, R. R. Bidigare, S. J. McDonald, and D. L. Adkison. 1989. An upper slope "cold" seep community: Northern California. Limnology and Oceanography 34(3): 635-640. 
Kohout, F. A. 1966. SUBMARINE SPRINGS: A NEGLECTED PHENOMENON OF COASTAL HYDROLOGY. Symposium on hydrology and water resources development, CENTRAL TREATY ORGANIZATION, pp. 391-413.

Kulm, L. D. and E. Suess. 1990. Relationship Between Carbonate Deposits and Fluid Venting: Oregon Accretionary Prism. Lournal of Geophysical Research 95(B6): 8899-8915.

Kulm, L. D., E. Suess, T. M. Thomburg, R. W. Embley, D. M. Hussong, and J. M. Resig. 1986. Fluid venting processes and their relation to tectonic styles in subduction zones of the Eastern Pacific. Abstract of the International Kaike Conference on Subduction Zones. November 1986. Tokyo-Shimizu, 28-29.

Leslie, B. W., Hammond, D. E., W. M. Berelson, and S. P. Lund. 1990. Diagenesis in Anoxic Sediments From the California Continental Borderland and Its Influence on Iron, Sulfur, and Magnetite Behavior. Journal of Geophysical Research 95(B4): 4453-4470.

Libes, S. M. 1992. An Introduction to Marine Biogeochemistry. New York: John Wiley \& Sons, Inc.

Lonsdale, P. 1977. Clustering of suspension feeding macrobenthos near abyssal hydrothermal vents at oceanic spreading centers. Deep-Sea Research. 24: 857-863.

Lynn, D. C. and E. Bonatti. 1965. MOBILITY OF MANGANESE IN DIAGENESIS OF DEEP-SEA SEDIMENTS. Marine Geology 3: 457-474.

Mandl, G. and R. M. Harkness. 1987. Hydrocarbon migration by hydraulic fracturing. In Deformation of Sediments and Sedimentary Rocks, ed. M. E. Jones and R. M. F. Preston. Geological Society Special Publication, No. 29, 39-53.

Mann, U. 1990. Sedimentological and Petrophysical Aspects of Primary Petroleum Migration Pathways. In Sediments and Environmental Geechemistry, ed. D. Helig, R. Rothe, U. Förstner, and P. Stoffers, pp. 152178.

Martens, C. S. and R. A. Bemer. 1974. Methane Production in the Interstitial Waters of Sulfate-Depleted Marine Sediments. Science 185(4157): 11671169.

Martens, C. S., J. P. Chanton, and C. K. Paull. 1991. Biogenic methane from abyssal brine seeps at the base of the Florida escarpment. Geology 19: 851-854. 
Martin, B. D. 1964. MONTEREY SUBMARINE CANYON, CALIFORNIA: GENESIS AND RELATIONSHIP TO CONTINENTAL GEOLOGY. Ph.D. diss., University of Southern California.

Martin, J. B., D. L. Orange, T. D. Lorenson, and K. A. Kvenvolden. Submitted. CHEMICAL AND ISOTOPIC EVIDENCE OF GAS-INFLUENCED FLOW THROUGH SEDIMENTS IN MONTEREY BAY, CALIFORNIA. Loumal of Geophysical Research.

Martin, J. H. and R. M. Gordon. 1988. Northeast Pacific iron distributions in relation to phytoplankton productivity. Deep-Sea Research 35(2): 177 196.

Massoth, G. J. 1991. MECHANICAL SUAVE COMPONENTS. Pacific Marine Environmental Laboratory, National Oceanic and Atmospheric Administration, Seattle, Washington. November 24.

1991a. PMEL Scanner Hardware Description. Pacific Marine Environmental Laboratory, National Oceanic and Atmospheric Administration, Seattle, Washington. December 4.

Massoth, G. J., H. B. Milburn, K. S. Johnson, K. H. Coale, M. F. Stapp, C. Meinig, and E. T. Baker. 1991. A SUAVE (Submersible System Used to Assess Vented Emissions) Approach to Plume Sensing: The Buoyant Plume Experiment at Cleft Segment, Juan de Fuca Ridge and Plume Exploration Along EPR 9-11 ${ }^{\circ}$ N. EOS Transactions. American Geophysical Union 72(44): 234.

Masuzawa, T., N. Handa, H. Kitagawa, and M. Kusakabe. 1992. Sulfate reduction using methane in sediments beneath a bathyal "cold seep" giant clam community off Hatsushima Island, Sagami Bay, Japan. Earth and Planetary Science Letters 110: 39-50.

Mayer, L. A., A. N. Shor, J. H. Clarke, and D. J. W. Piper. 1988 Dense biological communities at $3850 \mathrm{~m}$ on the Laurentian Fan and their relationship to the deposits of the 1929 Grand Banks earthquake. Deep-Sea Research 35(8): $\quad 1235-1246$.

McAdoo, B. G., D. L. Orange, P. Bowering, C. Moore, P. Teas, H. Tobin, H. Chezar, H. Lee, Reed, R. Vail, M. Underwood, P. Linke, and M. Schluter. 1994. Fluid Flow and Submarine Canyons: Observations from an ALVIN and CameraTow Program on the Toe of the Cascadia Accretionary Complex, Offshore Oregon. EOS Transactions. American Geophysical Union 75(16): 324.

McManus, J., D. E. Hammond, W. M. Berelson, T. E. Kilgore, D. J. Demaster, O. G. Ragueneau, and R. W. Collier. 1995. Early diagenesis of biogenic opal: Dissolution rates, kinetics, and paleoceanographic implications. Deep-Sea Research 42(2-3): 871-903. 
Morton, J. L., R. A. Zicrenberg, and C. A. Reiss, ed. 1994. Geologic. Hydrothermal, and Biologic Studies at Escanaba Trough, Gorda Ridge. Offshore Northern California. U.S. GEOLOGICAL SURVEY Bulletin 2022. Denver CO: USGS Map Distribution.

Muir, K. S. 1977. INITIAL ASSESSMENT OF THE GROUND-WATER RESOURCES IN THE MONTEREY BAY REGION. CALIFORNIA. U.S. GEOLOGICAL SURVEY, Water-Resources Investigations 77-46.

1980. SEAWATER INTRUSION AND POTENTIAL YIELD OF AOUIFERS IN THE SOQUEL-APTOS AREA, SANTA CRUZ COUNTY. CALIFORNIA. U.S. GEOLOGICAL SURVEY, Water-Resources Investigations 82-84.

1982. GROUND WATER IN THE SEASIDE AREA MONTEREY COUNTY CALIFORNIA. U.S. GEOLOGICAL SURVEY, Water-Resources Investigations 82-10.

Murray, J. W., V. Grundmanis, and W. M. Smethie. 1978. Interstitial water chemistry in the sediments of Saanich Inlet. Geochimica et Cosmochimica Acta 42: 1011-1026.

Okutani, T. and K. Egawa. 1989. Descriptions of three new species of vesicomyid bivalves by the submersible Nautile from abyssal depths off Honshu, Japan. Yenus 45: 147-160.

Orange, D., H. G. Greene, C. McHugh, W. B. F. Ryan, D. Reed, J. Barry, R. Kochevar, and J. Connor. 1993. Fluid Expulsion Along Fault Zones and mud Volcanoes in Monterey Bay. EOS Transactions. American Geophysical Union 74(43): 242.

Orange, D. L., H. G. Greene, C. McHugh, D. Reed, J. Barry, and W. B. F. Ryan. Submitted a. Direct Evidence of Fluid Expulsion from Fault Zones, Aquifers, and Mud Volcanoes Observed on the Seafloor in Monterey Bay. California Geology.

Orange, D. L., H. G. Greene, D. Reed, J. B. Martin, C. M. McHugh, W. B. F. Ryan, and J. Barry. Submitted b. ROV Observations of Active and Dormant Mud Volcanism in Monterey Bay, Califomia. Lournal of Geophysical Research.

Paull, C. K., B. Hecker, R. Commeau, R. P. Freeman-Lynde, C. Neumann, W. P. Corso, S. Golubic, J. E. Hook, E. Sikes, and J. Curray. 1984. Biological Communities at the Florida Escarpment Resemble Hydrothermal Vent Taxa. Science 226(4677): 965-967.

Pedersen, T. F. and N. B. Price. 1982. The geochemistry of manganese carbonate in Panama Basin sediments. Geochimica et Cosmochimica Acta 46: $59-68$. 
Reed D. L., C. McHugh, and W. B. F. Ryan. 1992. MSSS-1 Survey of the Offshore San Gregorio Fault System: Implications for Recent Displacement. EQS Transactions. American Geophysical Union 73(43): 589.

Robison, B. H. 1992. Midwater Research Methods with MBARI's ROV. Marine Technology Society Journal 26(4): 32-39.

Rona, P. A., K. Boström, L. Laubier, and K. Smith, ed. 1983. Hydrothermal Processes at Seafloor Spreading Centers. New York: Plenum Press.

Rosenberg, L. I., and J. C. Clark. 1994. Final Technical Repor: QUATERNARY FAULTING OF THE GREATER MONTEREY AREA, CALIFORNIA, December 1994. Monterey CA: Stall, Gardner \& Dunne Inc.

Ruzicka, J. and E. H. Hansen. 1988. Flow Injection Analysis, 2d ed., WileyInterscience Publications Vol. 62: New York: John Wiley \& Sons.

Sakamoto-Amold, C. M., K. S. Johnson, and C. L. Beehler. 1986. Determination of hydrogen sulfide in seawater using flow injection analysis and flow analysis. Limnology and Oceanography 31(4): 894-900.

Shepard, F. P. 1963. Submarine Geology, 2nd ed. New York: Harper \& Row. 1973. Submarine Geology, 3rd ed. New York: Harper \& Row.

Smith, C. R., H. Kukert, R. A. Wheatcroft, P. A. Jumars, and J. W. Deming. 1989. Vent Fauna on whale remains. Nature 341(6237): 27-28.

Stakes, D., D. Orange, J. B. Paduan, and N. Maher. Submitted. Origin of Authigenic Cold-Seep Carbonates from Monterey Bay. Earth and Planetary Science Letters.

Starke, G. W., and A. D. Howard. 1968. Polygenetic origin of Monterey Submarine Canyon. Geological Society America Bulletin 79(7): 813-826.

Stetson, C. L., J. W. Masier, V. B. McIntyre, and T. E. Meredith. 1973. SEA WATER INTRUSION LOWER SALINAS VALLEY, MONTEREY COUNTY. State of California, The Resources Agency, Department of Water Resources, San Joaquin District.

Stumm, W. and J. J. Morgan. 1981. Aquatic Chemistry: An Introduction Emphasizing Chemical Equilibria in Natural Waters, 2nd. ed. New York: John Wiley and Sons.

Suess, E. 1979. Mineral phases formed in anoxic sediments by microbial decomposition of organic matter. Geochimica et Cosmochimica Acta 43: 339-352. 
Sucss, E., B. Carson, S. D. Ritger, J. C. Moore, M. L. Jones, L. D. Kulm, and G. R. Cochrane. 1985. BIOLOGICAL COMMUNITIES AT VENT SITES ALONG THE SUBDUCTION ZONE OFF OREGON. The Biological Society of Washington Bulletin 6: $475-484$.

Suess, E. and M. J. Whiticar. 1989. METHANE-DERIVED $\mathrm{CO}_{2}$ IN PORE FLUIDS EXPELLED FROM THE OREGON SUBDUCTION ZONE. Palaeogeography. Paleoclimatology. Paleoecology 71: 119-136.

Sullivan, D. E. 1994. THE ORIGIN, EVOLUTION, AND CONTEMPORARY MORPHOLOGY OF SOOUEL SUBMARINE CANYON, MONTEREY BAY CALIFORNIA. Masters of Science Thesis, San Jose State University and Moss Landing Marine Laboratories.

Thamdrup, B., H. Fossing, and B. B. Jørgensen. 1994. Manganese, iron, and sulfur cycling in a coastal marine sediment, Aarhus Bay, Denmark. Geochimica et Cosmochimica Acta 58(23): 5115-5129.

Thomsen, J., K. S. Johnson, and R. L. Petty. 1983. Determination of Reactive Silicate in Seawater by Flow Injection Analysis. Analytical Chemistry 55(14): $2378-2382$.

Truesdale, V. W. and C. J. Smith. 1975. The Formation of Molybdosilicic Acids from Mixed Solution of Molybdate and Silicate. Analyst 100: 203-212.

1976. The Automatic Determination of Silicate Dissolved in Natural Fresh Water by Means of Procedures Involving the Use of Either $\alpha$ - or $\beta$ Molybdosilicic Acid. Analyst 101: 19-31.

Tsunogai, U., J. Ishibashi, H. Wakita, T. Gamo, T. Masuzawa, T. Nakatsuka, Y. Nojiri, and T. Nakamura. 1996. Fresh water seepage and pore water recycling on the seafloor: Sagami Trough subduction zone, Japan. Earth and Planetary Science Letters 138(1-4): 157-168.

Ungerer, P. E., Behar, and D. Discamps. 1981. Tentative Calculation of the Overall Volume Expansion of Organic Matter during Hydrocarbon Genesis from Geochemistry Data. Implications for Primary Migration. Advances in Organic Geochemistry 15: 129-135.

Ungerer, P. and R. Pelet. 1987. Extrapolation of the kinetics of oil and gas formation from laboratory experiments to sedimentary basins. Nature 327(6117): $52-54$.

Vanek, V. and D. R. Lee. 1991. Mapping submarine groundwater discharge areas - an example from Laholm Bay, southwest Sweden. Limnology and Oceanography 36(6): 1250-1262. 
Vogt, P. R., K. Cranc, E. Sundvor, M. D. Max, S. L. Pfirman. 1994. Methanegenerated(?) pockmarks on young, thickly sedimented oceanic crust in the Arctic: Vestnesa ridge, Fram strait. Geology 22(March): 255-258.

Wilson, T. R. S., J. Thomson, D. J. Hydes, S. Colley, F. Culkin, and J. Sørensen. 1986. Oxidation Fronts in Pelagic Sediments: Diagenetic Formation of Metal-Rich Layers. Science 232: 972-974. 


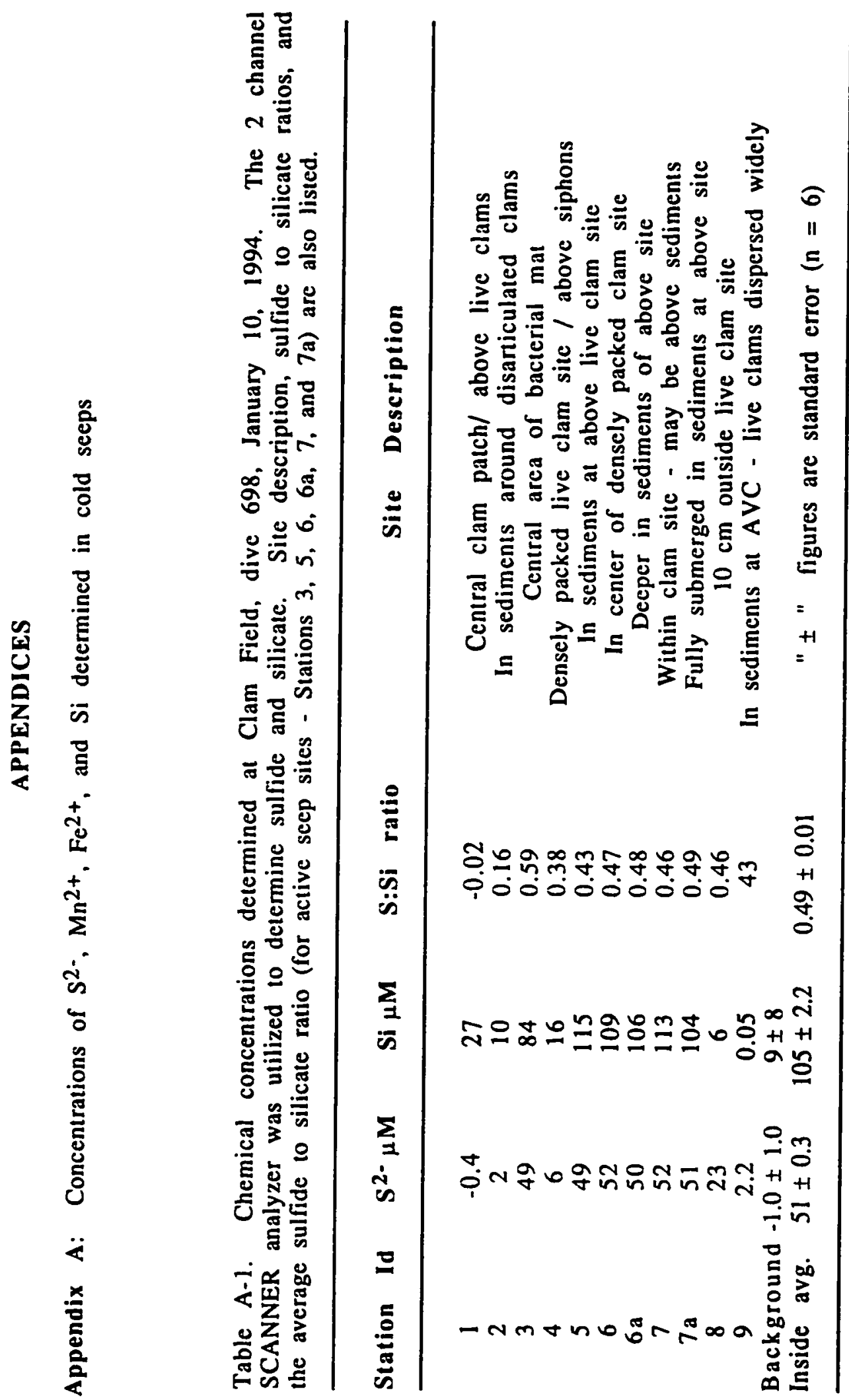




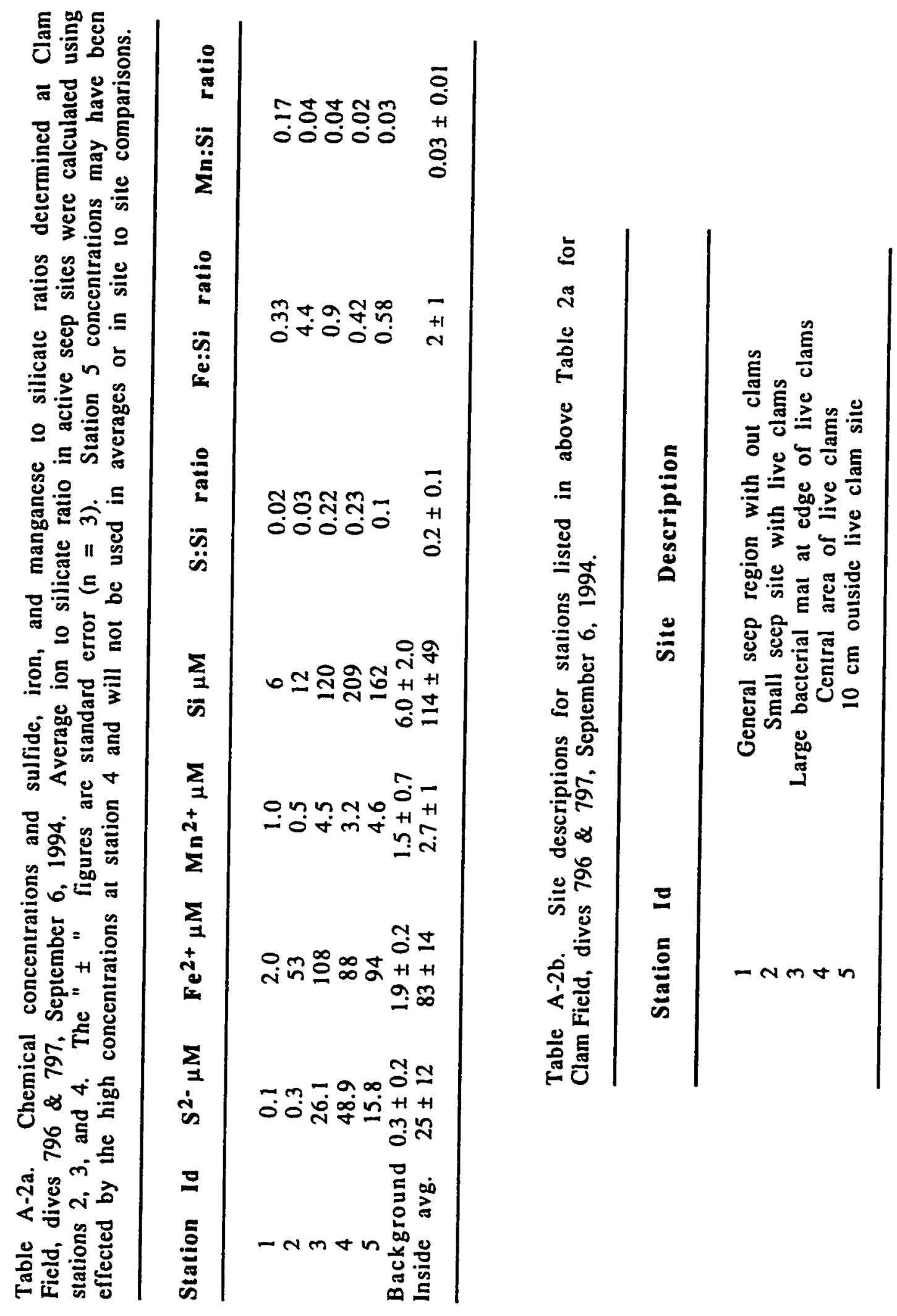




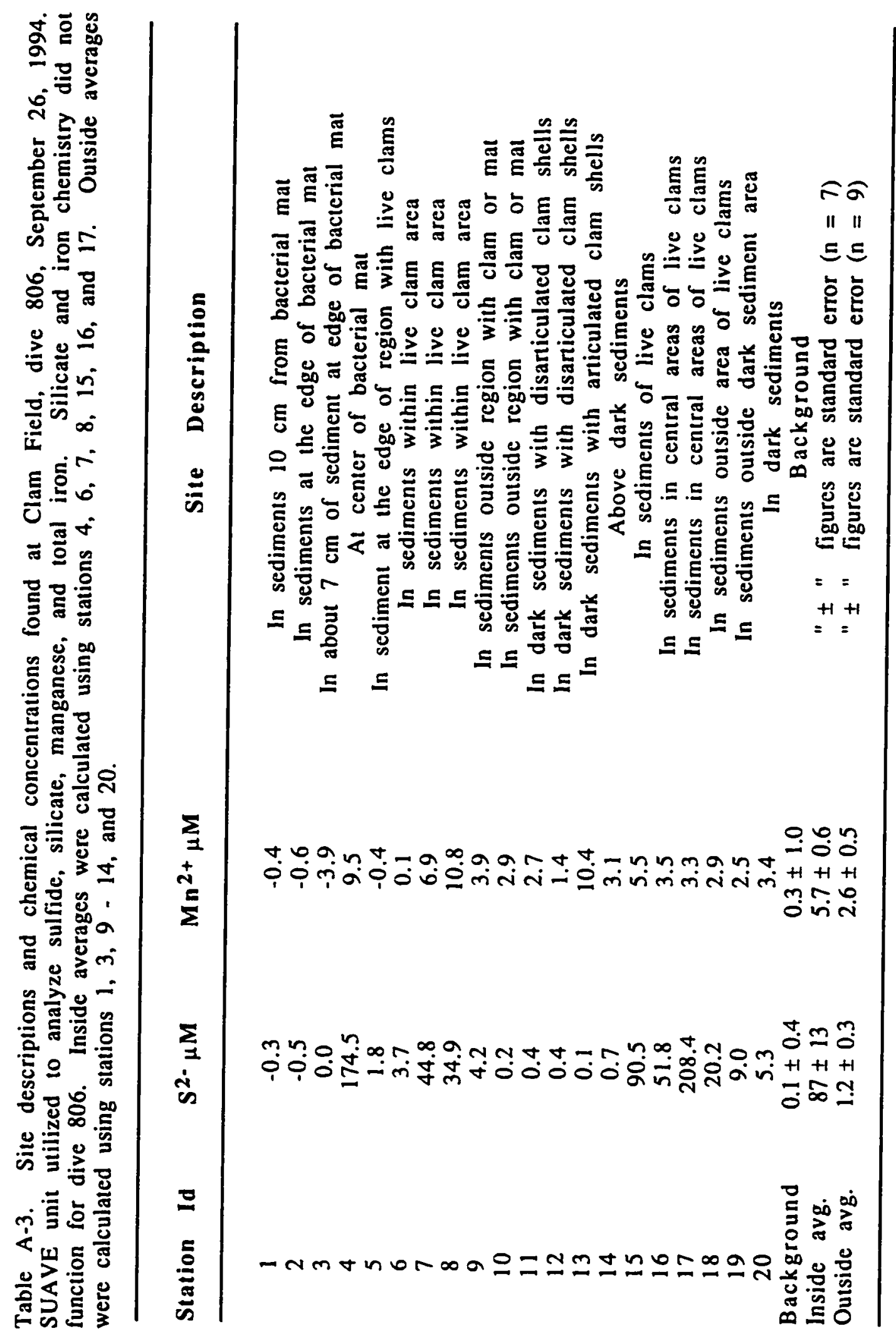




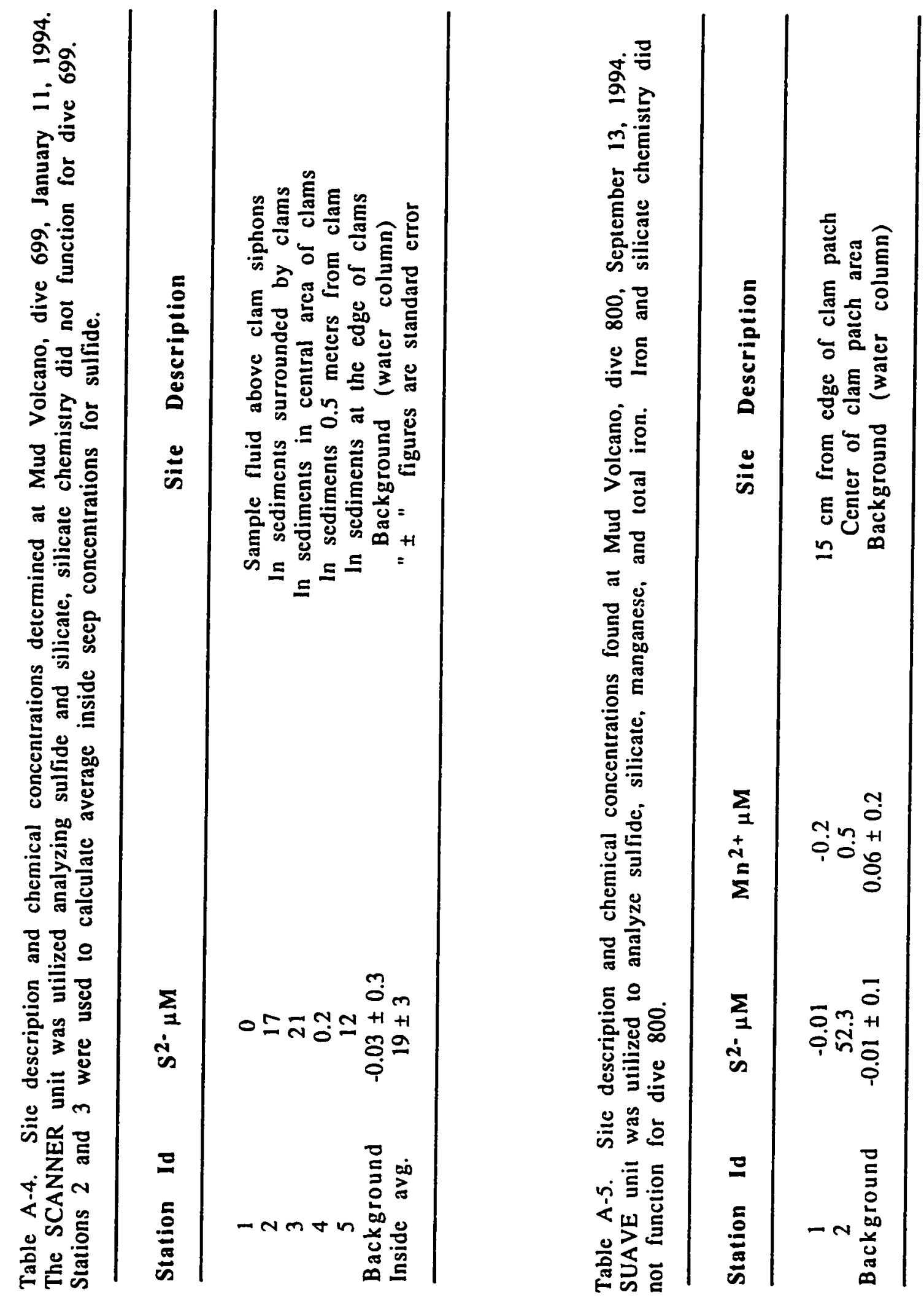




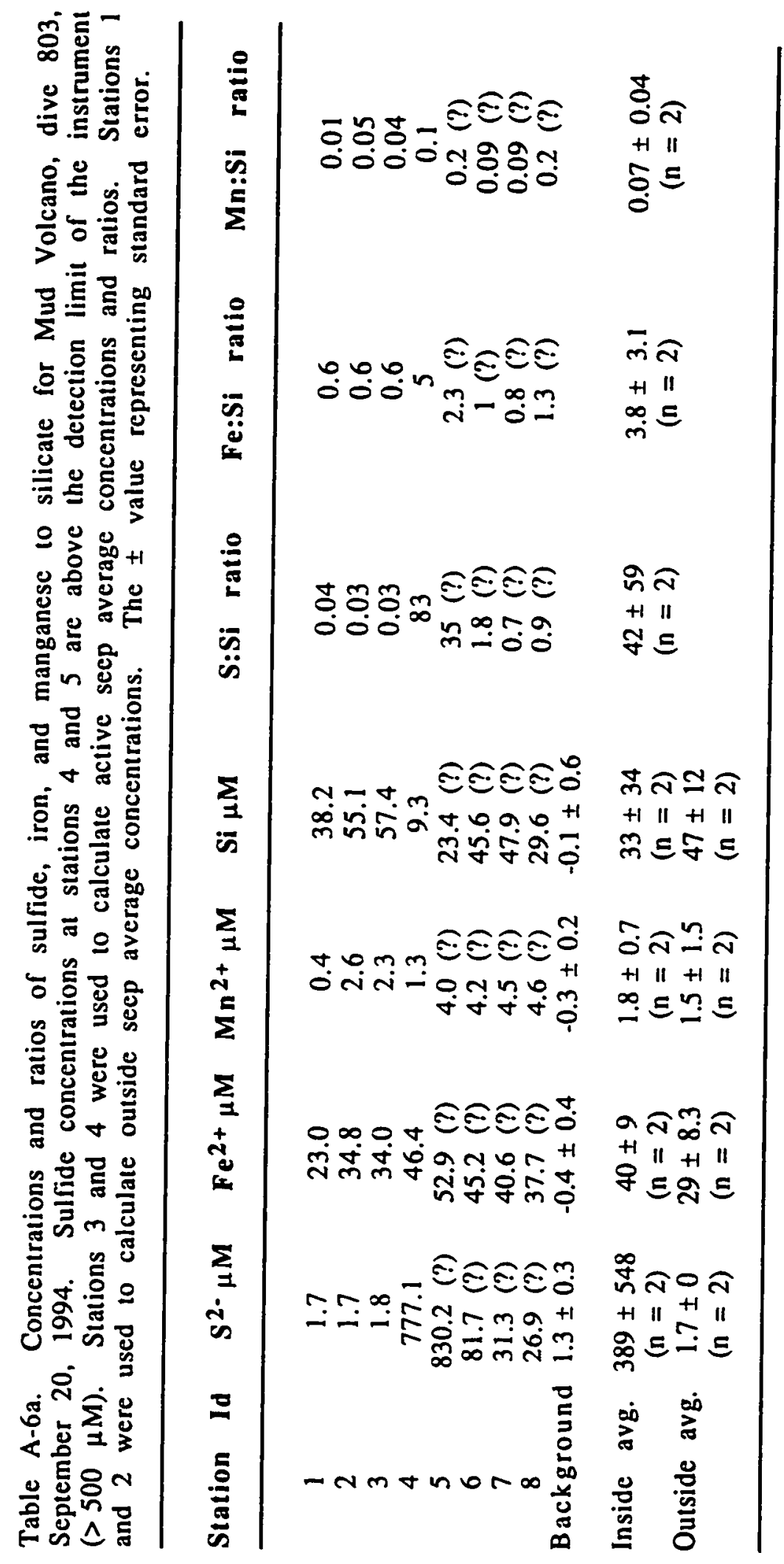




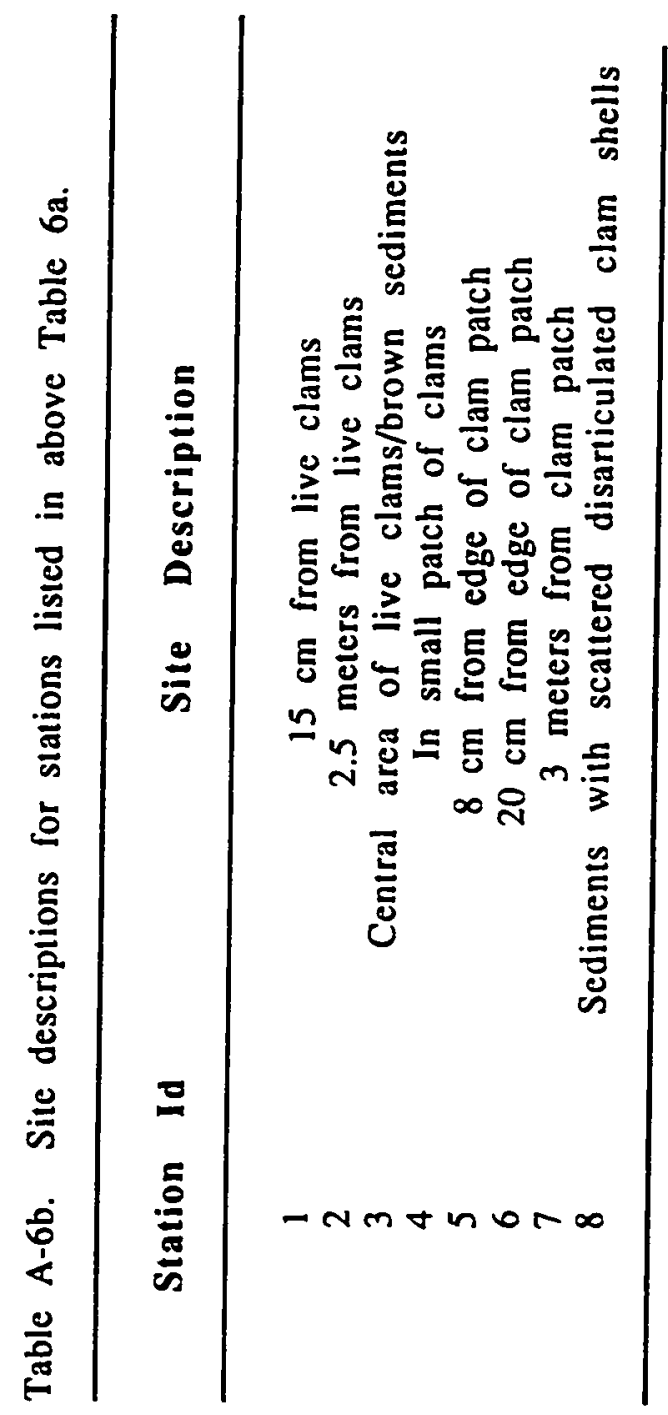




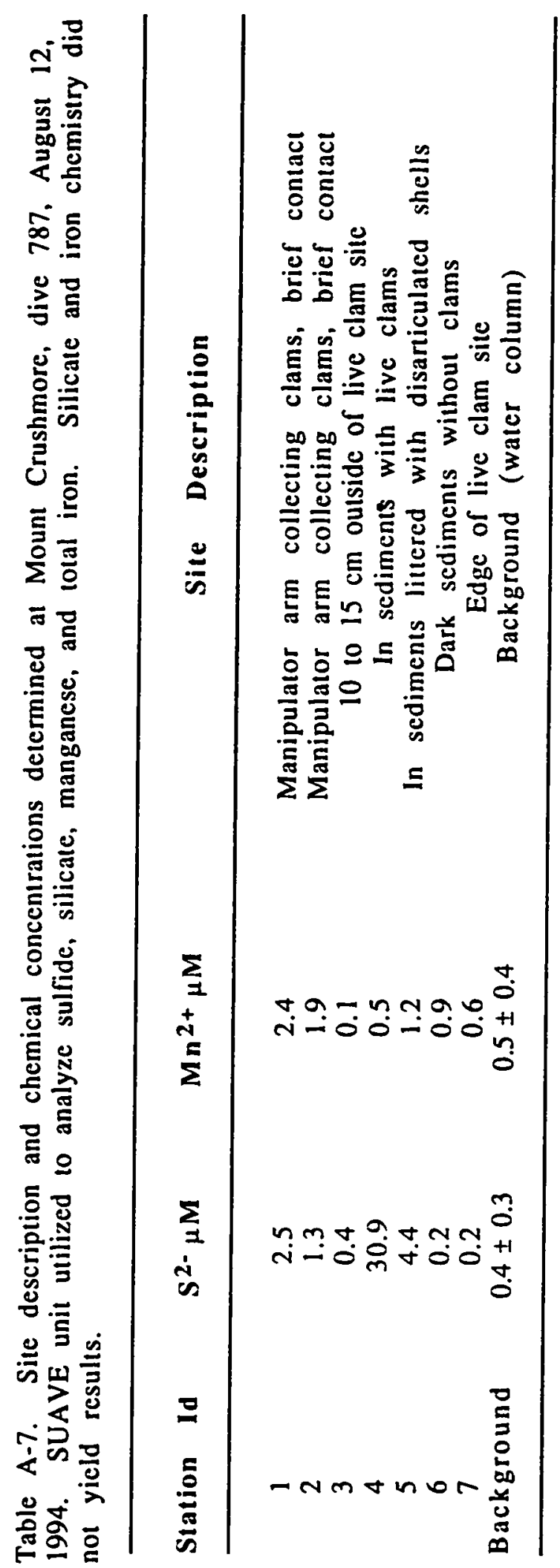




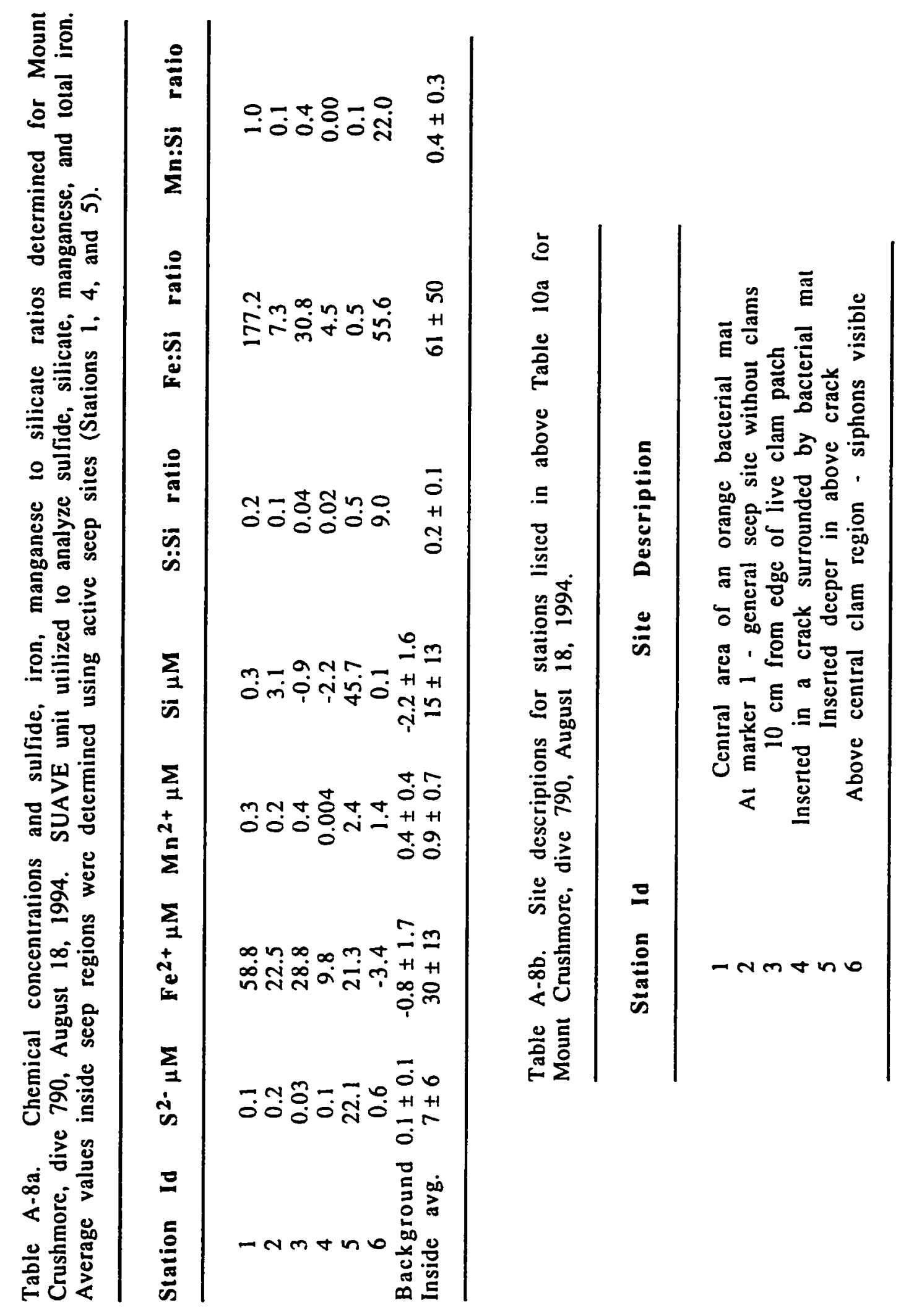




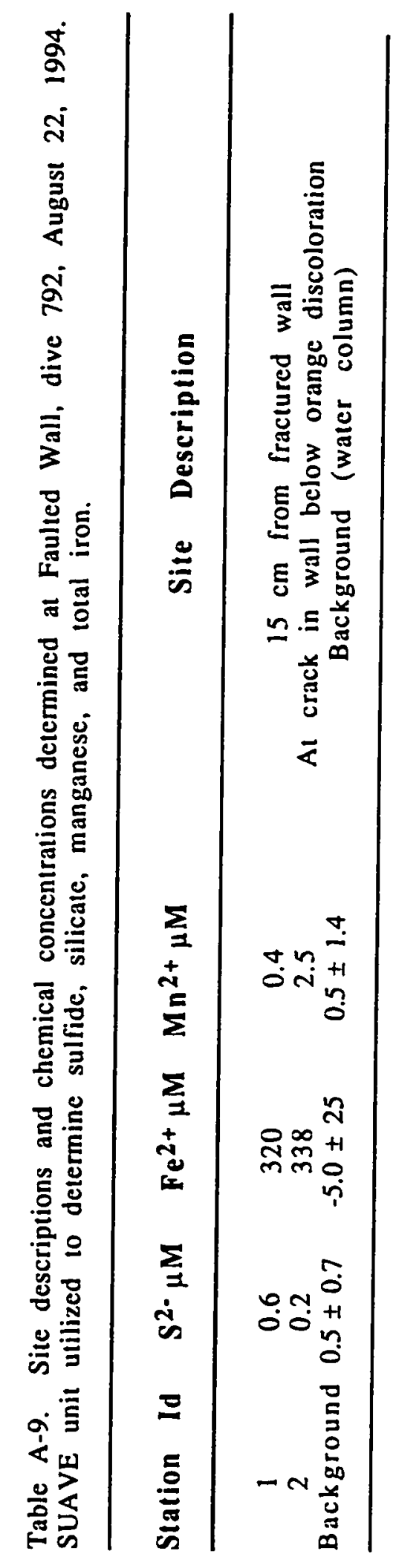


Appendix B: Statistical analysis of ion concentrations found inside and outside active seep stations within a seep site.

Table B-1. Inside and outside active seep region sulfide concentrations and the $\log (1+$ concentration of sulfide $)$ for Clam Field

\begin{tabular}{|c|c|c|c|c|}
\hline & $\begin{array}{l}\text { Outside Seep } \\
S^{2-} \mu \mathrm{M}\end{array}$ & $\begin{array}{c}\text { Inside Seep } \\
S^{2-} \mu M\end{array}$ & $\begin{array}{c}\text { Outside Seep } \\
\log \left(1+S^{2-} \mu M\right)\end{array}$ & $\begin{array}{c}\text { Inside Seep } \\
\log \left(1+S^{2-} \mu M\right)\end{array}$ \\
\hline $\begin{array}{l}\text { Avg. } \\
\text { Std. Err. }\end{array}$ & $\begin{array}{c}2 \\
23 \\
0.1 \\
-0.3 \\
4.2 \\
0.2 \\
0.4 \\
0.4 \\
0.1 \\
0.7 \\
5.3 \\
2.2\end{array}$ & $\begin{array}{c}5 \\
51 \\
49 \\
26.1 \\
174.5 \\
49 \\
0.3 \\
48.9 \\
90.5 \\
52 \\
50 \\
3.7 \\
44.8 \\
34.9 \\
51.8 \\
208.4 \\
58.7 \\
3.79 \\
\mathrm{n}=16\end{array}$ & $\begin{array}{c}0.47712125 \\
1.38021124 \\
0.04139269 \\
-0.154902 \\
0.71600334 \\
0.07918125 \\
0.14612804 \\
0.14612804 \\
0.04139269 \\
0.23044892 \\
0.79934055 \\
0.50514998\end{array}$ & $\begin{array}{c}0.77815125 \\
1.71600334 \\
1.69897 \\
1.43296929 \\
2.24427712 \\
1.69897 \\
0.11394335 \\
1.69810055 \\
1.96142109 \\
1.72427587 \\
1.70757018 \\
0.67209786 \\
1.66086548 \\
1.55509445 \\
1.72263392 \\
2.32097668 \\
1.54 \\
0.04 \\
n=16\end{array}$ \\
\hline
\end{tabular}

Table B-2. One-tail students t-test assuming equal variances of $\log (1+$ sulfide concentration) for Clam Field outside and inside sulfide seep measurements (Table B1)

\begin{tabular}{|c|c|c|}
\hline $\begin{array}{c}\text { Clam Field Sulfide t-test } \\
\text { Results }\end{array}$ & $\begin{array}{c}\text { Outside } \\
\log (1+\text { conc. })\end{array}$ & $\begin{array}{c}\text { Inside } \\
\log (1+\text { conc. })\end{array}$ \\
\hline $\begin{array}{c}\text { Mean } \\
\text { Variance } \\
\text { Observations } \\
\text { Pooled Variance } \\
\text { Hypothesized Mean Difference } \\
\mathrm{d} f \\
\mathrm{t} \text { Stat } \\
\mathrm{P}(\mathrm{T}<=\mathrm{t}) \text { one-tail } \\
\mathrm{t} \text { Critical one-tail }\end{array}$ & $\begin{array}{c}0.36729967 \\
0.18636421 \\
12 \\
0.2664909 \\
0 \\
26 \\
-5.9696628 \\
1.3312 \mathrm{E}-06 \\
1.70561634\end{array}$ & $\begin{array}{c}1.54414503 \\
0.32525048 \\
16\end{array}$ \\
\hline
\end{tabular}


Table B-3. Inside and outside active seep region iron concentrations and the $\log (1+$ concentration of iron) for Clam Field

\begin{tabular}{ccccc}
\hline $\begin{array}{c}\text { Outside Seep } \\
\mathrm{Fe}^{2+} \mu \mathrm{M}\end{array}$ & $\begin{array}{c}\text { Inside Seep } \\
\mathrm{Fe}^{2+} \mu \mathrm{M}\end{array}$ & $\begin{array}{c}\text { Outside Seep } \\
\log \left(1+\mathrm{Fe}^{2+} \mu \mathrm{M}\right)\end{array}$ & $\begin{array}{c}\text { Inside Seep } \\
\log \left(1+\mathrm{Fe}^{2+} \mu \mathrm{M}\right)\end{array}$ \\
\hline & 2 & 108 & 0.47712125 & 2.03743 \\
& & 53 & & 1.73239 \\
Avg. & 2 & 88 & $\mathrm{n} / \mathrm{a}$ & 1.94939 \\
Std. Err. & $\mathrm{n} / \mathrm{a}$ & 83 & $\mathrm{n} / \mathrm{a}$ & 1.91 \\
& $\mathrm{n}=1$ & 13.9 & $\mathrm{n}=1$ & 0.08 \\
& & $\mathrm{n}=3$ & & $\mathrm{n}=3$ \\
\hline
\end{tabular}

Table B-4. One-tail students t-test assuming equal variances of $\log (1+$ iron concentration $)$ for Clam Ficld outside and inside iron seep measurements (Table B3)

\begin{tabular}{ccc}
\hline $\begin{array}{c}\text { Clam Ficld Iron t-test } \\
\text { Results }\end{array}$ & $\begin{array}{c}\text { Outside } \\
\log (1+\text { conc. })\end{array}$ & $\begin{array}{c}\text { Inside } \\
\log (1+\text { conc. })\end{array}$ \\
\hline Mean & 0.47712125 & 1.90640342 \\
Variance & $\begin{array}{l}\text { DIV } / 0 ! \\
\text { Observations }\end{array}$ & 0.02464713 \\
Pooled Variance & 0.02464713 & 3 \\
Hypothesized Mean Difference & 0 & \\
df & 2 & \\
t Stat & -7.8843419 & \\
$\mathrm{P}(\mathrm{T}<=t)$ one-tail & 0.00785436 & \\
\hline Critical one-tail & 2.91998731 & \\
\hline
\end{tabular}


Table B-5. Inside and outside active seep region manganese concentrations and the $\log (1+$ concentration of manganese) for Clam Field

\begin{tabular}{|c|c|c|c|c|}
\hline & $\begin{array}{l}\text { Outside Seep } \\
\mathrm{Mn}^{2+} \mu \mathrm{M}\end{array}$ & $\begin{array}{c}\text { Inside Seep } \\
\mathrm{Mn}^{2+} \mu \mathrm{M}\end{array}$ & $\begin{array}{c}\text { Outside Seep } \\
\log \left(1+\mathrm{Mn}^{2+} \mu \mathrm{M}\right)\end{array}$ & $\begin{array}{c}\text { Inside Seep } \\
\log \left(1+\mathrm{Mn}^{2}+\mu \mathrm{M}\right)\end{array}$ \\
\hline $\begin{array}{l}\text { Avg. } \\
\text { Std. Err. }\end{array}$ & $\begin{array}{c}1 \\
-0.4 \\
3.9 \\
2.9 \\
2.7 \\
1.4 \\
10.4 \\
3.1 \\
3.4 \\
-0.6 \\
2.78 \\
0.34 \\
\mathrm{n}=10\end{array}$ & $\begin{array}{c}4.5 \\
9.5 \\
0.5 \\
3.2 \\
5.5 \\
0.1 \\
6.9 \\
10.8 \\
3.5 \\
3.3 \\
4.78 \\
0.39 \\
\mathrm{n}=10\end{array}$ & $\begin{array}{c}0.30103 \\
-0.2218487 \\
0.69019608 \\
0.59106461 \\
0.56820172 \\
0.38021124 \\
1.05690485 \\
0.61278386 \\
0.64345268 \\
-0.39794 \\
0.42240563 \\
0.048 \\
n=10\end{array}$ & $\begin{array}{c}0.74036269 \\
1.0211893 \\
0.17609126 \\
0.62324929 \\
0.81291336 \\
0.04139269 \\
0.89762709 \\
1.07188201 \\
0.65321251 \\
0.63346846 \\
0.66713886 \\
0.037 \\
\mathrm{n}=10\end{array}$ \\
\hline
\end{tabular}

Table B-6. One-tail students t-test assuming equal variances of $\log (1+$ manganese concentration) for Clam Field outside and inside iron seep measurements (Table B5)

\begin{tabular}{|c|c|c|}
\hline $\begin{array}{c}\text { Clam Field Manganese t-test } \\
\text { Results }\end{array}$ & $\begin{array}{c}\text { Outside } \\
\log (1+\text { conc. })\end{array}$ & $\begin{array}{c}\text { Inside } \\
\log (1+\text { conc. })\end{array}$ \\
\hline $\begin{array}{c}\text { Mean } \\
\text { Variance } \\
\text { Observations } \\
\text { Pooled Variance } \\
\text { Hypothesized Mean Difference } \\
\mathrm{df} \\
\mathrm{t} \text { Stat } \\
\mathrm{P}(\mathrm{T}<=\mathrm{t}) \text { one-tail } \\
\mathrm{t} \text { Critical one-tail }\end{array}$ & $\begin{array}{c}0.42240563 \\
0.19040579 \\
10 \\
0.15102764 \\
0 \\
18 \\
-1.4081527 \\
0.08806176 \\
1.73406306\end{array}$ & $\begin{array}{c}0.66713886 \\
0.11164949 \\
10\end{array}$ \\
\hline
\end{tabular}


Table B-7. Inside and outside active seep region silicate concentrations and the $\log (1+$ concentration of silicate $)$ for Clam Field

\begin{tabular}{|c|c|c|c|c|}
\hline & $\begin{array}{l}\text { Outside Seep } \\
\text { Si } \mu \mathrm{M}\end{array}$ & $\begin{array}{c}\text { Inside } \text { Seep } \\
\text { Si } \mu \mathrm{M}\end{array}$ & $\begin{array}{c}\text { Outside Seep } \\
\log (1+S i \mu M)\end{array}$ & $\begin{array}{c}\text { Inside Seep } \\
\log (1+S i \mu M)\end{array}$ \\
\hline $\begin{array}{l}\text { Avg. } \\
\text { Std. Err. }\end{array}$ & $\begin{array}{r}7.33 \\
1.15 \\
\mathrm{n}=3\end{array}$ & $\begin{array}{c}113 \\
104 \\
84 \\
120 \\
115 \\
12 \\
209 \\
109 \\
106 \\
108 \\
6.29 \\
n=9\end{array}$ & $\begin{array}{c}1.041392685 \\
0.84509804 \\
0.84509804\end{array}$ & $\begin{array}{c}2.05690485 \\
2.0211893 \\
1.92941893 \\
2.08278537 \\
2.06445799 \\
1.11394335 \\
2.32221929 \\
2.04139269 \\
2.02938378 \\
1.96 \\
0.04 \\
n=9\end{array}$ \\
\hline
\end{tabular}

Table B-8. One-tail students t-test assuming equal variances of $\log (1+$ silicate concentration $)$ for Mud Volcano outside and inside silicate seep measurements (Table B7)

\begin{tabular}{ccc}
\hline $\begin{array}{c}\text { Clam Field Silicate t-test } \\
\text { Results }\end{array}$ & $\begin{array}{c}\text { Outside } \\
\log (1+\text { conc. })\end{array}$ & $\begin{array}{c}\text { Inside } \\
\log (1+\text { conc. })\end{array}$ \\
\hline Mean & 0.91052959 & 1.96241062 \\
Variance & 0.01284386 & 0.11230736 \\
Observations & 3 & 9 \\
Pooled Variance & 0.09241466 & \\
Hypothesized Mean Difference & 0 & \\
df & 10 & \\
t Stat & -5.1902401 & \\
$\mathrm{t}(\mathrm{T}<=\mathrm{t})$ one-tail & 0.0002035 & \\
\hline
\end{tabular}


Table B-9. Inside and outside active seep region sulfide concentrations and the $\log (1+$ concentration of sulfide $)$ for Mud Volcano

\begin{tabular}{lcccc}
\hline $\begin{array}{c}\text { Outside Seep } \\
\mathrm{S}^{2-} \mu \mathrm{M}\end{array}$ & $\begin{array}{c}\text { Inside Seep } \\
\mathrm{S}^{2-} \mu \mathrm{M}\end{array}$ & $\begin{array}{c}\text { Outside Seep } \\
\log \left(1+\mathrm{S}^{2-} \mu \mathrm{M}\right)\end{array}$ & $\begin{array}{c}\text { Inside Seep } \\
\log \left(1+\mathrm{S}^{2-} \mu \mathrm{M}\right)\end{array}$ \\
\hline & 0.2 & 17 & 0.07918125 & 1.25527251 \\
& -0.01 & 21 & -0.0043648 & 1.34242268 \\
& 1.7 & 52.3 & 0.43136376 & 1.72672721 \\
& 1.7 & 1.8 & 0.43136376 & 0.44715803 \\
Avg. & 0.90 & 777 & & 2.89103542 \\
Std. Err. & 0.31 & 174 & 0.23438599 & 1.53252317 \\
& $\mathrm{n}=4$ & $\mathrm{n}=5$ & 0.07666448 & 0.22270687 \\
& & & $\mathrm{n}=4$ & $\mathrm{n}=5$ \\
\hline
\end{tabular}

Table B-10. One-tail students t-test assuming equal variances of $\log (1+$ sulfide concentration $)$ for Mud Volcano outside and inside sulfide scep measurements (Table B9)

\begin{tabular}{ccc}
\hline Mud $\begin{array}{c}\text { Volcano Sulfide t-test } \\
\text { Results }\end{array}$ & $\begin{array}{c}\text { Outside } \\
\log (1+\text { conc. })\end{array}$ & $\begin{array}{c}\text { Inside } \\
\log (1+\text { conc. })\end{array}$ \\
\hline Mean & 0.23438599 & 1.53252317 \\
Variance & 0.05289698 & 0.79357359 \\
Observations & 4 & 5 \\
Pooled Variance & 0.47614075 & \\
Hypothesized Mean Difference & 0 & \\
df Stat & -2.8044432 & \\
P(T<=t) one-tail & 0.01317772 & \\
Critical one-tail & 1.89457751 & \\
\hline
\end{tabular}


Table B-11. Inside and outside active seep region iron concentrations and the $\log (1+$ concentration of iron $)$ for Mud Volcano

\begin{tabular}{lcccc}
\hline $\begin{array}{c}\text { Outside Seep } \\
\mathrm{Fe}^{2+} \mu \mathrm{M}\end{array}$ & $\begin{array}{c}\text { Inside Seep } \\
\mathrm{Fe}^{2+} \mu \mathrm{M}\end{array}$ & $\begin{array}{c}\text { Outside Seep } \\
\log \left(1+\mathrm{Fe}^{2+} \mu \mathrm{M}\right)\end{array}$ & $\begin{array}{c}\text { Inside Seep } \\
\log \left(1+\mathrm{Fe}^{2+} \mu \mathrm{M}\right)\end{array}$ \\
\hline & 23 & 34 & 1.38021124 & 1.54406804 \\
Avg. & 34.8 & 46.4 & 1.55388303 & 1.67577834 \\
Std. Err. & 8.34 & 40.2 & 1.47 & 1.61 \\
& $\mathbf{n}=2$ & 8.77 & 0.12 & 0.09 \\
& $\mathrm{n}=2$ & $\mathrm{n}=2$ & $\mathrm{n}=2$ \\
\hline
\end{tabular}

Table B-12. One-tail students t-test assuming equal variances of $\log (1+$ iron concentration $)$ for Mud Volcano outside and inside iron seep measurements (Table B11)

\begin{tabular}{|c|c|c|}
\hline $\begin{array}{l}\text { Mud Volcano Iron t-test } \\
\text { Results }\end{array}$ & $\begin{array}{c}\text { Outside } \\
\log (1+\text { conc. })\end{array}$ & $\begin{array}{c}\text { Inside } \\
\log (1+\text { conc. })\end{array}$ \\
\hline $\begin{array}{c}\text { Mean } \\
\text { Variance } \\
\text { Observations } \\
\text { Pooled Variance } \\
\text { Hypothesized Mean Difference } \\
\mathrm{df} \\
\mathrm{t} \text { Stat } \\
\mathrm{P}(\mathrm{T}<=\mathrm{t}) \text { one-tail } \\
\mathrm{t} \text { Critical one-tail }\end{array}$ & $\begin{array}{c}1.46704713 \\
0.01508094 \\
2 \\
0.01187737 \\
0 \\
2 \\
-1.3109897 \\
0.16008208 \\
2.91998731\end{array}$ & $\begin{array}{c}1.60992319 \\
0.0086738 \\
2\end{array}$ \\
\hline
\end{tabular}


Table B-13. Inside and outside active seep region manganese concentrations and the $\log (1+$ concentration of manganese) for Mud Volcano

\begin{tabular}{ccccc}
\hline $\begin{array}{c}\text { Outside Seep } \\
\mathrm{Mn}^{2+} \mu \mathrm{M}\end{array}$ & $\begin{array}{c}\text { Inside Seep } \\
\mathrm{Mn}^{2+} \mu \mathrm{M}\end{array}$ & $\begin{array}{c}\text { Outside Seep } \\
\log \left(1+\mathrm{Mn}^{2+} \mu \mathrm{M}\right)\end{array}$ & $\begin{array}{c}\text { Inside Seep } \\
\log \left(1+\mathrm{Mn}^{2+\mu \mathrm{M})}\right.\end{array}$ \\
\hline & 0.4 & 2.3 & 0.14612804 & 0.51851394 \\
Avg. & 2.6 & 1.3 & 0.36172784 & 0.361727836 \\
Std. Err. & 1.5 & 1.8 & 0.35121527 & 0.440120888 \\
& 1.6 & 0.71 & 0.29003715 & 0.110864517 \\
& $\mathrm{n}=2$ & $\mathrm{n}=2$ & $\mathrm{n}=2$ & \\
\hline
\end{tabular}

Table B-14. One-tail students t-test assuming equal variances of $\log (1+$ manganese concentration $)$ for Mud Volcano outside and inside manganese seep measurements (Table B13)

\begin{tabular}{|c|c|c|}
\hline $\begin{array}{c}\text { Mud Volcano Manganese t-test } \\
\text { Results }\end{array}$ & $\begin{array}{c}\text { Outside } \\
\log (1+\text { conc. })\end{array}$ & $\begin{array}{c}\text { Inside } \\
\log (1+\text { conc. })\end{array}$ \\
\hline $\begin{array}{c}\text { Mean } \\
\text { Variance } \\
\text { Observations } \\
\text { Pooled Variance } \\
\text { Hypothesized Mean Difference } \\
\text { df } \\
t \text { Stat } \\
P(T<=t) \text { one-tail } \\
t \text { Critical one-tail }\end{array}$ & $\begin{array}{c}0.35121527 \\
0.08412155 \\
2 \\
0.04820624 \\
0 \\
2 \\
-0.4049278 \\
0.36236709 \\
2.91998731\end{array}$ & $\begin{array}{c}0.44012089 \\
0.01229094 \\
2\end{array}$ \\
\hline
\end{tabular}


Table B-15. Inside and outside active seep region silicate concentrations and the $\log (1+$ concentration of silicate $)$ for Mud Volcano

\begin{tabular}{lcccc}
\hline $\begin{array}{c}\text { Outside Seep } \\
\text { Si } \mu \mathrm{M}\end{array}$ & $\begin{array}{c}\text { Inside Scep } \\
\text { Si } \mu \mathrm{M}\end{array}$ & $\begin{array}{c}\text { Outside Seep } \\
\log (1+\text { Si } \mu \mathrm{M})\end{array}$ & $\begin{array}{c}\text { Inside Seep } \\
\log (1+\text { Si } \mu \mathrm{M})\end{array}$ \\
\hline & -0.2 & 0.5 & -0.09691 & 0.17609126 \\
& 38.2 & 57.4 & 1.59328607 & 1.76641285 \\
Avg. & 31.03 & 9.3 & 1.74896286 & 1.01283722 \\
Std. Err. & 14.17 & 30.6 & 1.08177964 & 0.98511378 \\
& $\mathbf{n}=3$ & 15.31 & 0.51186932 & 0.39776159 \\
& $\mathrm{n}=3$ & $\mathrm{n}=3$ & $\mathrm{n}=3$ \\
\hline
\end{tabular}

Table B-16. One-tail students t-test assuming equal variances of $\log (1+$ silicate concentration $)$ for Mud Volcano outside and inside silicate scep measurements (Table B 15)

\begin{tabular}{|c|c|c|}
\hline $\begin{array}{c}\text { Mud Volcano Silicate t-test } \\
\text { Results }\end{array}$ & $\begin{array}{c}\text { Outside } \\
\log (1+\text { conc. })\end{array}$ & $\begin{array}{c}\text { Inside } \\
\log (1+\text { conc. })\end{array}$ \\
\hline $\begin{array}{c}\text { Mean } \\
\text { Variance } \\
\text { Observations } \\
\text { Pooled Variance } \\
\text { Hypothesized Mean Difference } \\
\mathrm{df} \\
\mathrm{t} \text { Stat } \\
\mathrm{P}(\mathrm{T}<=\mathrm{t}) \text { one-tail } \\
\mathrm{t} \text { Critical one-tail }\end{array}$ & $\begin{array}{c}1.08177964 \\
1.04804079 \\
3 \\
0.84044896 \\
0 \\
4 \\
0.12914068 \\
0.45173977 \\
2.13184649\end{array}$ & $\begin{array}{c}0.98511378 \\
0.63285713 \\
3\end{array}$ \\
\hline
\end{tabular}


Table B-17. Inside and outside active seep region sulfide concentrations and the $\log (1+$ concentration of sulfide $)$ for Mount Crushmore

\begin{tabular}{lcccc}
\hline $\begin{array}{c}\text { Outside Seep } \\
\mathrm{S}^{2-} \mu \mathrm{M}\end{array}$ & $\begin{array}{c}\text { Inside Seep } \\
\mathrm{S}^{2-} \mu \mathrm{M}\end{array}$ & $\begin{array}{c}\text { Outside Seep } \\
\log \left(1+\mathrm{S}^{2-} \mu \mathrm{M}\right)\end{array}$ & $\begin{array}{c}\text { Inside Seep } \\
\log \left(1+\mathrm{S}^{2-} \mu \mathrm{M}\right)\end{array}$ \\
\hline & 0.03 & 22.1 & 0.01283722 & 1.36361198 \\
& 0.4 & 0.1 & 0.14612804 & 0.04139269 \\
Avg. & 0.2 & 30.9 & 0.07918125 & 1.50379068 \\
Std. Err. & 0.21 & 17.7 & 0.07938217 & 0.96959845 \\
& 0.09 & 7.9 & 0.03332282 & 0.4034498 \\
& $\mathrm{n}=3$ & $\mathrm{n}=3$ & $\mathrm{n}=3$ & $\mathrm{n}=3$ \\
\hline
\end{tabular}

Table B-18. One-tail students t-test assuming equal variances of $\log (1+$ sulfide concentration) for Mount Crushmore outside and inside sulfide seep measurements (Table B17)

\begin{tabular}{ccc}
\hline Mount $\begin{array}{c}\text { Crushmore Sulfide t-test } \\
\text { Results }\end{array}$ & $\begin{array}{c}\text { Outside } \\
\log (1+\text { conc. })\end{array}$ & $\begin{array}{c}\text { Inside } \\
\log (1+\text { conc. })\end{array}$ \\
\hline Mean & 0.07938217 & 0.96959845 \\
Variance & 0.00444164 & 0.65108697 \\
Observations & 3 & 3 \\
Pooled Variance & 0.32776431 & \\
Hypothesized Mean Difference & 0 & \\
df f & 4 & \\
$\mathrm{t}$ Stat & -1.9044095 & \\
$\mathrm{P}(\mathrm{T}<=\mathrm{t})$ one-tail & 0.06478912 & \\
\hline
\end{tabular}


Table B-19. Inside and outside active seep region iron concentrations and the $\log (1+$ concentration of iron) for Mount Crushmore

\begin{tabular}{|c|c|c|c|c|}
\hline & $\begin{array}{c}\text { Outside Seep } \\
\mathrm{Fe}^{2+} \mu \mathrm{M}\end{array}$ & $\begin{array}{c}\text { Inside Seep } \\
\mathrm{Fe}^{2+} \mu \mathrm{M}\end{array}$ & $\begin{array}{c}\text { Outside Seep } \\
\log \left(1+\mathrm{Fe}^{2+} \mu \mathrm{M}\right)\end{array}$ & $\begin{array}{c}\text { Inside Seep } \\
\log \left(1+\mathrm{Fe}^{2+} \mu \mathrm{M}\right)\end{array}$ \\
\hline $\begin{array}{l}\text { Avg. } \\
\text { Sid. Err. }\end{array}$ & $\begin{array}{c}28.8 \\
28.8 \\
n / a \\
n=1\end{array}$ & $\begin{array}{c}21.3 \\
58.8 \\
40.05 \\
26.5 \\
\mathrm{n}=2\end{array}$ & 1.47421626 & $\begin{array}{c}1.34830486 \\
1.77670118 \\
1.56 \\
0.30 \\
\mathrm{n}=2\end{array}$ \\
\hline
\end{tabular}

Table B-20. One-tail students t-test assuming equal variances of

$\log (1+$ iron concentration) for Mount Crushmore outside and inside iron seep measurements (Table B19)

\begin{tabular}{|c|c|c|}
\hline $\begin{array}{c}\text { Mount Crushmore Iron t-test } \\
\text { Results }\end{array}$ & $\begin{array}{l}\text { Outside } \\
\log (1+\text { conc. })\end{array}$ & $\begin{array}{c}\text { Inside } \\
\log (1+\text { conc. })\end{array}$ \\
\hline $\begin{array}{c}\text { Mean } \\
\text { Variance } \\
\text { Observations } \\
\text { Pooled Variance } \\
\text { Hypothesized Mean Difference } \\
\mathrm{df} \\
\mathrm{t} \text { Stat } \\
\mathrm{P}(\mathrm{T}<=\mathrm{t}) \text { one-tail } \\
\mathrm{t} \text { Critical one-tail }\end{array}$ & $\begin{array}{c}1.47421626 \\
\# D I V / 0 ! \\
1 \\
0.0917617 \\
0 \\
1 \\
-0.2379684 \\
0.42563546 \\
6.3137486\end{array}$ & $\begin{array}{c}1.56250302 \\
0.0917617 \\
2\end{array}$ \\
\hline
\end{tabular}


Table B-21. Inside and outside active seep region manganese concentrations and the $\log (1+$ concentration of manganese $)$ for Mount Crushmore

\begin{tabular}{lcccc}
\hline $\begin{array}{c}\text { Outside Seep } \\
\mathrm{Mn}^{2+} \mu \mathrm{M}\end{array}$ & $\begin{array}{c}\text { Inside Seep } \\
\mathrm{Mn}^{2}+\mu \mathrm{M}\end{array}$ & $\begin{array}{c}\text { Outside Seep } \\
\log \left(1+\mathrm{Mn}^{2+} \mu \mathrm{M}\right)\end{array}$ & $\begin{array}{c}\text { Inside Seep } \\
\log \left(1+\mathrm{Mn}^{2+} \mu \mathrm{M}\right)\end{array}$ \\
\hline & 0.4 & 2.4 & 0.146128036 & 0.531478917 \\
& 0.1 & 0.3 & 0.041392685 & 0.113943352 \\
Avg. & 0.9 & & 0.278753601 & 0.32 \\
Std. Err. & 0.46 & 1.35 & 0.15 & 0.29 \\
& 0.20 & 1.48 & 0.06 & $\mathrm{n}=2$ \\
\hline
\end{tabular}

Table B-22. One-tail students t-test assuming equal variances of $\log (1+$ manganese concentration $)$ for Mount Crushmore outside and inside manganese seep measurements (Table B21)

\begin{tabular}{|c|c|c|c|}
\hline Mount & $\begin{array}{c}\text { Crushmore Manganese t-test } \\
\text { Results }\end{array}$ & $\begin{array}{l}\text { Outside } \\
\log (1+\text { conc. })\end{array}$ & $\begin{array}{c}\text { Inside } \\
\log (1+\text { conc. })\end{array}$ \\
\hline Hypo & $\begin{array}{c}\text { Mean } \\
\text { Variance } \\
\text { Observations } \\
\text { Pooled Variance } \\
\text { thesized Mean Difference } \\
\text { df } \\
t \text { Stat } \\
P(T<=t) \text { one-tail } \\
t \text { Critical one-tail }\end{array}$ & $\begin{array}{c}0.155424774 \\
0.014149873 \\
3 \\
0.03848924 \\
0 \\
3 \\
-0.93407444 \\
0.209585071 \\
2.353363016\end{array}$ & $\begin{array}{c}0.322711135 \\
0.087167974 \\
2\end{array}$ \\
\hline
\end{tabular}


Table B-23. Inside and outside active seep region silicate concentrations and the $\log (1+$ concentration of silicate) for Mount Crushmore

\begin{tabular}{|c|c|c|c|c|}
\hline & $\begin{array}{l}\text { Outside Seep } \\
\text { Si } \mu \mathrm{M}\end{array}$ & $\begin{array}{c}\text { Inside Seep } \\
\text { Si } \mu \mathrm{M}\end{array}$ & $\begin{array}{c}\text { Outside Seep } \\
\log (1+S i \mu M)\end{array}$ & $\begin{array}{c}\text { Inside Seep } \\
\log (1+S i \mu M)\end{array}$ \\
\hline $\begin{array}{l}\text { Avg. } \\
\text { Std. Err. }\end{array}$ & $\begin{array}{l}-0.9 \\
-0.9 \\
\mathrm{n} / \mathrm{a} \\
\mathrm{n}=1\end{array}$ & $\begin{array}{c}45.7 \\
0.3 \\
23 \\
32.1 \\
\mathrm{n}=2\end{array}$ & $\begin{array}{c}-1 \\
n=1\end{array}$ & $\begin{array}{c}1.669316881 \\
0.113943352 \\
0.89 \\
1.10 \\
n=2\end{array}$ \\
\hline
\end{tabular}

Table B-24. One-tail students t-test assuming equal variances of $\log (1+$ silicate concentration) for Mount Crushmore outside and inside silicate seep measurements (Table B23)

\begin{tabular}{ccc}
\hline Mount $\begin{array}{c}\text { Crushmore Silicate } \\
\text { Results }\end{array}$ & $\begin{array}{c}\text { Outside } \\
\log (1+\text { conc. })\end{array}$ & $\begin{array}{c}\text { Inside } \\
\log (1+\text { conc. })\end{array}$ \\
\hline Mean & -1 & 0.89163012 \\
Variance & $\begin{array}{c}1 \\
\text { Observations }\end{array}$ & 1.20959341 \\
Pooled Variance & 1.20959341 & \\
Hypothesized Mean Difference & 0 & \\
df & 1 & \\
$\mathrm{t}$ Stat & -1.4043355 & \\
$\mathrm{P}(\mathrm{T}<=t)$ one-tail & 0.19696627 & \\
\hline
\end{tabular}

